\title{
UM MODELO PARA DIMENSIONAMENTO DE CALÇADAS CONSIDERANDO O NÍVEL DE SATISFAÇÃO DO PEDESTRE
}

Marcus Vinicius Guerra Seraphico de Assis Carvalho

Tese apresentada à Escola de Engenharia de São Carlos da Universidade de São Paulo, como parte dos requisitos para obtenção do título de Doutor em Engenharia Civil: Planejamento e Operação de Sistemas de Transportes.

Orientador: Prof. Dr. Manoel Henrique Alba Sória

São Carlos

2006 
Ficha catalográfica preparada pela Seção de Tratamento da Informação do Serviço de Biblioteca - EESC/USP

C331m

Carvalho, Marcus Vinicius Guerra Seraphico de Assis Um modelo para dimensionamento de calçadas considerando o nível de satisfação do pedestre / Marcus Vinicius Guerra Seraphico de Assis Carvalho. -- São Carlos, 2006.

Tese (Doutorado) -- Escola de Engenharia de São Carlos-Universidade de São Paulo, 2006.

Área: Engenharia de Transportes.

Orientador: Prof. Dr. Manoel Henrique Alba Sória.

1. Planejamento de transportes. 2. Dimensionamento de calçadas. 3. Pedestres. 4. Nível de serviço de calçadas. 5. Ciclistas. 6. Modelo. 7. Transporte não motorizado. 8. Planejamento urbano I. Título. 
Dedico este trabalho aos meus pais, João Baptista e Nazaré Seraphico, por todo o apoio e incentivo que me mantiveram perseverante nesta jornada.

Ao professor Manoel Sória, pela orientação.

Ao professor Eiji Kawamoto, pelo companheirismo, empenho e colaboração, atributos indispensáveis para o cumprimento de mais uma etapa em minha vida. 


\section{AGRADECIMENTOS}

Gostaria de agradecer a Deus por me mostrar sempre respostas às questões árduas da vida, e me confortar nos momentos difíceis.

Ao professor e orientador, Manoel Sória, pelo estímulo, confiança, apoio, presteza e conselhos dados a mim, mesmo quando estive afastado de São Carlos.

Ao professor Eiji Kawamoto, ser humano fantástico, pessoa indispensável para que este trabalho fosse realizado. Por toda a sua atenção, comprometimento, dedicação e espírito de colaboração, minha eterna gratidão.

Agradeço aos meus pesquisadores de campo: Wolmar, Laurilane, Gregório e Paulo, pela cooperação nesta pesquisa.

Agradeço ao professor Antônio Nelson pela atenção e companheirismo.

Agradeço ao Professor Glauco, por toda a amizade e colaboração nesta jornada.

A todos os professores do STT, sem exceção, pela contribuição no meu amadurecimento profissional.

A minha família: avó, tios, tias, primos e primas, em especial, aos meus pais (João e Nazaré), minhas irmãs (Socorro e Ana Maria), meus cunhados (Joaquim e Nilson) e meus sobrinhos (Amanda, André e Adrianinha), por sempre transmitirem a mim, mesmo distantes, sentimentos de carinho, incentivo e confiança.

Agradeço ao Dr Drumma que, com suas palavras e sabedoria, sempre me faz acreditar que grandes conquistas são possíveis.

A dona Nazaré e seu Macedo, por toda a torcida e apoio.

Agradeço a Ana Paula, pelos conselhos, opiniões e toda a ajuda prestada durante este trabalho, e estendo minha gratidão a toda a família Furlan por ter me recebido muito bem neste estado.

Quero agradecer à família QG \& Base Aérea: Ricardinho, Rafael, Rômulo, João Marcello, Alexandre (Topó), Renatão, Mário Garrido, Cláudio Dubeaux, Manuel Lucas, Everton, Renatinho, Pablo, Massulo, Gustavão, Zanchetta, Giovane, Cida Cris, Adriana, Nívea, Josi, Marcela, Cynthia, Karenina, Cira, Cíntia, Márcia e Juliana. Obrigado por todo o apoio e torcida. Valeu Diretoria!!!

Agradeço também aos amigos Carlos Prado e Heliana, por todo o apoio em São Carlos e pelas refeições oferecidas.

Ao amigo Dinato, pelo constante incentivo e atenção.

Ao amigo Adalberto Faxina, pelas colaborações e companheirismo.

Ao amigo Gigante, meu enorme respeito, por todos os ensinamentos e colaboração na minha vida profissional. 
A turma do café da manhã: Paulão, João, Carlão (Toco), Vicentão, Paulinho e Alexandre, muito obrigado pela força.

Agradeço a dona Heloisa, a dona Magali, a Beth e a Suely e a todos os funcionários do STT, que colaboraram para este trabalho.

Gostaria de agradecer aos novos amigos: André, Weslley, Francis, Jesner, Jorge, Camilla, Andréa, Celane e Vivianne, por todo o carinho dispensado a minha pessoa.

Em especial quero agradecer aos amigos de sala: Mateus, Bruno e Cira, pelo convívio companheirismo e pela imensa colaboração que me prestaram no desenvolvimento desta tese.

Agradeço ao Departamento de Estrutura da UFRR, e ao Diretor do CCT, professor Antônio Alves, pelo apoio prestado. Agradeço aos professores Leon e Katri Tolstoi, e em especial, agradeço aos professores João Bosco, Ary, Gioconda e Pablo, por acompanharem de perto esta jornada.

Agradeço a Ana Claudia que sempre torceu por mim. Obrigado pelas orações, incentivo e companheirismo.

Aos amigos Bailosa, Beto, Elton, Leo, Flávio, Ricardo e todos os que jogam aquele futebol no amigão, obrigado.

Ao Moisés Mourão, meu estatístico, pela ajuda no início da pesquisa.

A toda moçada cativa da toca do Negão: Amaury, Maneca, Vitão, Luiz, Pablo, Moisés, Cássio, Lucas, Dani, Elaine, Vanessa, Bia, Laís e Milene, por toda a torcida e momentos de lazer na Macuxilândia.

Muito obrigado! 
"O pessimista se queixa do vento, o otimista espera que ele mude e o realista ajusta as velas."

William George Ward 


\section{RESUMO}

Carvalho, M.V.G.S.A.. Um modelo para dimensionamento de calçadas considerando o nível de satisfação do pedestre. 2006. 150 f. Tese (Doutorado). Escola de Engenharia de São Carlos, Universidade de São Paulo, São Carlos, 2006.

Neste trabalho é apresentado um modelo para dimensionamento de calçadas considerando o nível de satisfação do pedestre. O modelo foi desenvolvido com base em pesquisa conduzida na cidade de Boa Vista, Roraima. Apesar de a cidade apresentar uma demanda razoável de viagens realizadas por bicicletas, não possui uma infra-estrutura adequada para ciclistas, razão porque uma parte considerável dos ciclistas trafega pela calçada. Por este motivo, foi incluído no modelo proposto o fluxo total de ciclistas na via, uma variável que não é mencionada em nenhum outro método de avaliação do nível de serviço de calçadas. Para desenvolver o modelo foram utilizadas as técnicas de árvore de decisão e de regressão robusta MM, contidas no programa S-Plus 6.1. A partir da comparação com outros trabalhos analisados, será mostrado que, desconsiderando o fluxo de ciclistas, o modelo elaborado é compatível com outros desenvolvidos em várias partes do mundo. Devido a limitações da amostragem e caráter local da área estudada, não há elementos suficientes para se afirmar que o modelo ora proposto seja amplamente utilizável quando se considera o fluxo de ciclistas. Porém, mostra-se que, além de permitir avaliar o nível de serviço de calçadas, o modelo pode ser usado no dimensionamento de tais infra-estruturas, sendo útil, portanto, no planejamento urbano.

Palavras-chave: Dimensionamento de calçadas. Pedestres. Nível de serviço de calçadas. Ciclistas. Modelo. Transporte não motorizado. Planejamento Urbano. 


\begin{abstract}
Carvalho, M.V.G.S.A.. A model for sidewalk sizing considering the level of satisfaction of the pedestrian. 2006. $150 \mathrm{f}$. Thesis (Doctorate). São Carlos School of Engineering, University of São Paulo, 2006.
\end{abstract}

This thesis presents a model for determining sidewalk width taking into account the level of pedestrian satisfaction. The model was developed using the data collected in the city of Boa Vista, State of Roraima, Brazil. Although cycling demand in the city is not low, Boa Vista does not have any facilities for cyclists. As a consequence, a part of them rides on the sidewalk. Taking this reason into account, the total flow of cyclists on the street was included in the proposed model, a variable not mentioned in other methods for evaluating pedestrian level of service on sidewalks. Decision tree and MM robust regression techniques available in S-Plus 6.1 software were used to develop the model. From a comparison with other works, it is shown that, without the cyclists flow, the proposed model provides results that are similar to those of other authors. Due to sample size and geographic limitations of this research, there are still not enough elements to affirm that the model is widely applicable when the cyclists flow on the sidewalk. However, the present work shows that besides the capability to evaluate the sidewalk level of service, the model can also be used for sidewalk sizing and thus, it is a useful tool on urban planning.

Keywords: Sidewalk Sizing. Pedestrian. Sidewalk Level of Service. Cyclists. Model. NonMotorized Transport. Urban Planning. 



\section{CAPÍTULO 1}

$\begin{array}{ll}\text { INTRODUÇÃO } & 1\end{array}$

1.Introdução 1

1.1 Caracterização do Problema 1

1.2 Justificativa da Pesquisa 4

$\begin{array}{ll}1.3 \text { Objetivo da Pesquisa } & 7\end{array}$

1.4 Relevância da Pesquisa $\quad 7$

1.5 Estrutura do Texto $\quad 8$

\section{CAPÍTULO 2}

CONSIDERAÇÕES SOBRE O TRANSPORTE NÃO MOTORIZADO 10

2.1 Introdução 10

2.2 A Inserção dos Pedestres no Sistema Viário Urbano 11

2.3 A Infra-Estrutura para a Circulação de Pedestres 14

2.3.1. Elementos de Projeto 15

2.4 A Utilização das Calçadas em Função do Uso do Solo e do Perfil dos 19 Pedestres

2.5. Medida do Nível de Serviço das Calçadas $\quad 21$

2.6 Comentários Sobre os Métodos Utilizados para Medir Nível de Serviço 35 de Calçadas

$\begin{array}{ll}2.7 \text { Considerações Finais } & 37\end{array}$

CAPÍTULO 3

A CIRCULAÇÃO DOS TRANSPORTES NÃO MOTORIZADOS NA CIDADE DE BOA VISTA X A NOVA POLÍTICA NACIONAL DE 38 TRÂNSITO

3.1introdução 38

3.2 Localização e Aspectos Gerais da Cidade de Boa Vista 38

3.3 As Condições de Caminhada dos Pedestres em Boa Vista 40

3.4 A Influência dos Ciclistas na Circulação Urbana de Boa Vista 42

3.5 A Nova Política Nacional de Trânsito

3.6 Considerações Finais $\quad 53$

CAPÍTULO 4

MÉTODO UTILIZADO NA PESQUISA 56

4.1 Introdução 56

4.2 A Hipótese Considerada na Pesquisa 56

4.3 Coleta de Dados $\quad 59$

4.3.1 Seleção e Caracterização das Vias 59 
4.3.2 Caracterização dos Aspectos Geométricos das Vias 60

4.3.2.1 Aspectos Relacionados à Pista de Rolamento 60

4.3.2.2 Aspectos Relacionados à Calçada $\quad 61$

4.3.3 Caracterização dos Aspectos Operacionais das Vias 62

4.3.3.1 Caracterização do Fluxo de Veículos Motorizados 62

4.3.3.2 Caracterização do Fluxo de Pedestres e Ciclistas 64

4.3.4 Considerações Sobre a Pesquisa de Opinião com Pedestres 65

4.4 Processamento dos Dados Coletados e Obtenção de Modelos 67

4.4.1 Árvore de Decisão $\quad 69$

4.4.1.1 Definição das Variáveis de Maior Influência na Satisfação dos 73 Pedestres

4.4.2 Técnicas de Regressão Robusta 74

4.4.2.1 Obtenção do Modelo para Dimensionamento de Calçadas 77

$\begin{array}{ll}4.5 \text { Verificação do Modelo } & 78\end{array}$

\section{CAPÍTULO 5}

CARACTERIZAÇÃO DAS VIAS ONDE FORAM REALIZADAS AS 80 CONTAGENS

5.1 Introdução $\quad 80$

5.2 Seleção das Vias Estudadas 80

5.3Características Funcionais, Geométricas e Físicas das Vias Estudadas 81

5.3.1 Av. General Athayde Teive $\quad 81$

5.3.2 Av. Mário Homem de Mello 83

5.3.3 Av. Brigadeiro Eduardo Gomes 86

5.4 Características Operacionais das Vias Estudadas 87

\section{CAPÍTULO 6}

DADOS E PROCESSAMENTO

6.1 Introdução 98

6.2. Processamento dos Dados 98

6.3 Obtenção dos Resultados da Árvore de Decisão 100

6.4 Modelo para Dimensionamento de Calçadas em Vias Urbanas 108

\section{CAPÍTULO 7}

\section{ANÁLISE DOS RESULTADOS}

7.1 Introdução 111

7.2 Compatibilidade do Modelo Proposto com o HCM (2000) 112

7.2.1 Considerações Sobre O Modelo Proposto 112

7.2.2 Comparação dos Resultados do Modelo Proposto com o HCM 115 (2000) 
7.3 Comparação dos Resultados do Modelo Proposto com Outros

Estudos

7.4 Fronteiras Para os Níveis de Serviço Definidos pelo Modelo Proposto

125

Considerando os Ciclistas da Via

7.5 Utilização Do Modelo Proposto Para Dimensionamento De Calçadas

Em Vias Urbanas

CAPÍTULO 8

CONCLUSÕES, RECOMENDAÇÕES E SUGESTÕES PARA

TRABALHOS FUTUROS

REFERÊNCIAS

150

APÊNDICE A - Exemplos da Planilha de Contagem 


\section{Capítulo 1}

\section{INTRODUÇÃO}

Este capítulo inicia com uma breve caracterização do problema estudado, mostrando a preocupação existente por parte dos planejadores de transportes, com relação às deficiências de infra-estrutura destinada à circulação de pedestres no meio urbano. A partir da contextualização do problema são apresentados ainda, a justificativa e o objetivo da pesquisa. Por fim, é mostrada a forma como foi estruturada a pesquisa, e que conteúdo pode ser encontrado em cada um dos seus capítulos.

\subsection{CARACTERIZAÇÃO DO PROBLEMA}

Pode-se constatar, em nosso país, que tem havido um crescimento constante do uso do automóvel, fato este comprovado pela diminuição contínua da taxa de habitantes por veículo ao longo dos anos. Segundo a Associação Nacional de Transportes Públicos (ANTP, 2001) na década de 1970 essa taxa era de 30 e na década de 1990 era de 9 habitantes/veículo, chegando a 6 habitantes/veículo em 1995. 
Como primeira conseqüência deste incremento, pôde-se sentir um aumento de tráfego nas vias dos grandes centros, ocasionando enormes congestionamentos e ao mesmo tempo causando estresse e fadiga não só aos condutores de veículos, como também aos seus passageiros. Em muitos locais, a infra-estrutura viária já não era mais suficiente para suportar a demanda existente.

Assim, a maioria dos gestores municipais começou a criar mais infra-estrutura no espaço urbano para os veículos motorizados, relegando ainda mais os transportes não motorizados (TNM) ao abandono. Desta forma, e como herança dessa prática de gestão, aos poucos, os espaços urbanos perderam não só suas áreas verdes, como também, deixaram de ser atrativos aos transportes não motorizados, devido à ausência de facilidades a estes destinadas.

De fato, a Associação Nacional de Transportes Públicos (ANTP, 1997) constata que o uso intenso do automóvel na circulação urbana causa dispersão e fragmentação excessiva do uso do solo, sobretudo na distribuição de empregos. Além disso, a imagem de altíssima acessibilidade que ele oferece, acrescido à plena capacidade de inserção urbana dos veículos - embora comprometida nas grandes cidades pelos congestionamentos - exerce ainda forte atração sobre os usuários e vai aos poucos transformando os espaços de circulação de pedestres e áreas verdes de convivência em estacionamentos potenciais.

Para Gondim (2001), a adequação das vias para atender o transporte motorizado, além de prejudicar sensivelmente a circulação do transporte não motorizado - estreitando calçadas para o alargamento das vias carroçáveis, aumenta a exposição do pedestre aos riscos das travessias e, dos passeios retira os espaços das árvores para abrigar vagas de automóveis, estendendo a distância de percurso e aumentando a insegurança para os transeuntes. $\mathrm{O}$ aumento das áreas de estacionamentos na malha urbana cria zonas áridas desconfortáveis e inseguras para caminhar. 
Na prática, o que se tem observado é uma grande parcela da sociedade, representada pelos pedestres, utilizando as vias urbanas em situações muito desfavoráveis: sobre calçamentos irregulares, ou em acostamentos deteriorados, e ainda, em situação de maior risco, disputando espaços com veículos automotores, junto ao meio-fio das vias urbanas.

A calçada ou passeio público é um dos componentes básicos de uma via e tem como principal função, garantir condições adequadas de circulação dos pedestres. Entretanto, podem-se observar nas calçadas de muitas cidades brasileiras, defeitos superficiais, larguras insuficientes de passagem, rampas excessivas, obstáculos fixos e vegetações mal aparadas, que comprometem a funcionalidade de tais infra-estruturas. Acredita-se que esses fatores prejudicam a qualidade dos deslocamentos dos pedestres, podendo inclusive provocar a subutilização das calçadas e gerar alguns acidentes, devido à evasão de pedestres para os bordos da via.

O Instituto de Pesquisa Econômica e Aplicada (IPEA, 2003) destaca que, mais de 30 \% dos deslocamentos realizados em áreas urbanas, nas cidades brasileiras, são feitos a pé, e que, tradicionalmente, os acidentes de trânsito incluem apenas os acidentes envolvendo veículos. As estatísticas referentes a esses acidentes já destacam o pedestre, vítima de atropelamento - cerca de 50 \% das mortes - como o elemento mais vulnerável no trânsito.

Para Hook (1995) a utilização de transporte não motorizado não representa uma questão de subdesenvolvimento, pelo contrário, pode significar um aumento na produção econômica de uma cidade. Conforme Gondim (2001), para possibilitar e estimular a locomoção a pé ou de bicicleta é necessário prover as cidades de uma infra-estrutura compatível com as necessidades de pedestres e ciclistas. Atualmente o uso do solo urbano é parcialmente regulamentado pela Lei 6.766 de 1979 e suas alterações (tramita na esfera federal o Projeto de Lei 3.057/2000, a chamada Lei de Responsabilidade Territorial Urbana). De acordo com a Lei hoje em vigor, "Os Estados, o Distrito Federal e os Municípios poderão estabelecer normas complementares relativas ao parcelamento do solo municipal para adequar o previsto nesta Lei 
às peculiaridades regionais e locais." Por força dessa faculdade, os principais municípios da União têm sua chamadas Leis de Parcelamento, Uso e Ocupação do Solo. Seria nessa instância que o encorajamento ao transporte não motorizado poderia ser feito.

Atualmente, pode-se observar que mesmo em cidades onde existe um número relativamente alto de viagens utilitárias (destinadas ao trabalho, escola, supermercado, etc) realizadas a pé; a política de incentivo ao automóvel - adotada tacitamente há algum tempo em nosso país - e, a falta da infra-estrutura mínima para os transportes não motorizados, são fatores que contribuem para a queda de qualidade da caminhada dos pedestres, além de desestimular esta prática.

\subsection{JUSTIFICATIVA DA PESQUISA}

A Agenda 21, documento estabelecido pelas Nações Unidas, propõe a promoção do planejamento sustentável dos transportes em todos os países englobando as seguintes medidas: Estimular modos não motorizados de transportes, com a construção de ciclovias e vias para pedestres seguras nos centros urbanos e suburbanos nos países em que isso for apropriado.

As recomendações da Agenda 21 são válidas para grandes e pequenas cidades, mesmo com pequenos índices de veículos por habitantes. O objetivo é prevenir quanto à necessidade de implantação de um sistema de circulação adequado, para pedestres e ciclistas, antes que o uso do automóvel acabe por tornar as intervenções na infra-estrutura viária mais problemáticas e onerosas.

Entretanto, muitos dos municípios brasileiros não apresentam um panorama satisfatório em termos de calçadas. Mesmo os que têm um programa específico voltado para os passeios 
públicos, têm dificuldade de manter toda a sua rede em condições satisfatórias. Por esse motivo acredita-se que a qualidade de um deslocamento a pé, ou caminhada, pode ser avaliada. Pergunta-se, portanto, como avaliar a qualidade de um deslocamento a pé e quais os fatores que influenciam essa qualidade?

Alguns pesquisadores, ao longo do tempo, têm procurado responder a estas questões, porém, de forma isolada. Desta maneira, alguns estudos procuram avaliar o nível de serviço de calçadas, considerando o critério da capacidade, ou seja, consideram o fluxo de pedestres que atravessa uma determinada seção de calçada no intervalo de tempo de 1 minuto. Dentre esses estudos destacam-se os realizados por FRUIN (1971) e pelo Highway Capacity Manual (HCM, 2000).

Outros pesquisadores como Sarkar (1993), Khisty (1994) e Ferreira e Sanches (2001), desenvolveram estudos para avaliar o nível de serviço das calçadas, porém, o critério utilizado para este fim foi o da percepção dos pedestres sobre alguns atributos - segurança, seguridade, conforto, conveniência, atratividade e manutenção - que integram o ambiente de caminhada.

Pelo exposto até o presente momento, percebe-se que existem alguns assuntos ainda não abordados pelos pesquisadores e que pode influenciar a qualidade de caminhada dos pedestres. Dentre esses, pode-se destacar a influência negativa que a falta de uma infraestrutura adequada para a circulação de ciclistas, em cidades onde existe uma demanda relativamente alta para este tipo de viagem, causa para os pedestres, quando estes utilizam o espaço destinado aos seus deslocamentos. Ou seja, ainda não existem pesquisas que comprovem a perda do nível de serviço dos pedestres em função da utilização indevida dos passeios públicos pelos ciclistas.

Em pesquisa realizada em Gainesville, Florida, Dixon (1995), relatou haver uma forte relação entre o nível de serviço e a infra-estrutura de uma via, ou seja, ruas com falta de infra estrutura para pedestres e ciclistas apresentaram valores baixos para tal parâmetro. Porém, 
cabe destacar que na metodologia proposta pela autora, não houve a análise de dados de colisão entre pedestres e ciclistas, no cálculo do nível de serviço. A autora explica que altos volumes de veículos podem afastar os pedestres e ciclistas das vias. Assim, as taxas computadas de colisões terão valores mascarados, por falta desses elementos na via. Dados referentes a colisões podem ser utilizados para proporcionar um critério de validade das avaliações dos níveis de serviços.

Normalmente, o HCM (2000) aborda este tema com base no estudo de obstáculos, considerando, porém, caminhos compartilhados por ciclistas e pedestres. Mas, estas facilidades encontram-se nas margens das vias, ou seja, há praticamente um isolamento entre os transportes motorizados e não motorizados, o que reflete uma situação distinta da encontrada no meio urbano brasileiro, onde o conflito entre pedestres e ciclistas ocorre nas calçadas ou no próprio meio-fio das vias.

Assim, não é considerada a seguinte situação: quando o ciclista não tem espaço na vìa e acaba, em função de alguns parâmetros que condicionam o seu comportamento (fluxo de veículos da via, qualidade do pavimento, qualidade da calçada, etc), invadindo o espaço destinado ao pedestre, conseqüentemente, causando a perda de qualidade dos deslocamentos destes últimos.

Convém ressaltar que a situação de invasão por parte dos ciclistas, em calçadas públicas, pode ser observada freqüentemente no trânsito da cidade de Boa Vista e em muitas outras cidades de porte médio do nosso país.

Desta forma, com o intuito de procurar refletir melhor o comportamento dos pedestres, em suas caminhadas sobre as calçadas, propõe-se nesta pesquisa, a realização de um estudo mais detalhado sobre o nível de serviço das calçadas, considerando a influência dos aspectos físicos, geométricos e operacionais de uma via (inclusive a presença de ciclistas) sobre os pedestres, procurando mostrar quais os principais parâmetros que influenciam a caminhada. Tal estudo será 
de importância para que os gestores municipais possam planejar adequadamente os seus recursos destinados ao setor de transporte.

Entretanto, não é intenção desta pesquisa incentivar o uso irrestrito das calçadas de uma via pelos ciclistas. Porém, uma vez que o Código de Trânsito Brasileiro (CTB), de acordo com o seu art 59, permite, em determinadas situações, a circulação de bicicletas sobre as calçadas, pretende-se, a partir deste trabalho, planejar de maneira mais adequada os espaços destinados à circulação dos pedestres, considerando os possíveis conflitos destes usuários com os ciclistas.

\subsection{OBJETIVO DA PESQUISA}

Esta pesquisa tem como objetivo principal, a definição de um modelo para dimensionamento de calçadas em vias urbanas, considerando o nível de satisfação dos pedestres. Aliado a este objetivo principal e como forma de subsidiá-lo, esta pesquisa pretende definir os parâmetros que têm maior influência na satisfação do pedestre quando este efetua seu deslocamento sobre as calçadas e fica sujeito a todas as condições da via no tocante à geometria, operação e equipamentos urbanos (postes, orelhões, etc.).

\subsection{RELEVÂNCIA DA PESQUISA}

Segundo Moretti (1993) os equipamentos urbanos (poste de iluminação, telefone público, lixeiras, etc) são elementos que condicionam a via, interagindo entre si na circulação e gerando conflitos. 
A inserção desses aspectos se faz necessária uma vez que a utilização do Nível de Serviço sugerido nos normativos do HCM (2000) para vias urbanas considera situações incompatíveis com a realidade de muitas das vias urbanas brasileiras. Assim, os índices propostos nesse manual nem sempre refletem o nível de satisfação dos pedestres, quando estes estão expostos aos demais usuários e às condições operacionais de uma determinada via.

Esta pesquisa pode servir como subsídio aos gestores municipais, a fim de que possam perceber melhor que tipos de fatores podem influenciar negativamente os deslocamentos dos pedestres sobre as calçadas, nas vias onde não existem infra-estruturas para a circulação de ciclistas.

A partir desta pesquisa, os gestores municipais poderão desenvolver, dentro da especificidade de cada município, métodos próprios, a fim de melhor avaliar o nível de serviço prestado aos pedestres, como também, poderão utilizar dados mais confiáveis, para um melhor planejamento da circulação urbana, destinada aos transportes não-motorizados (TNM). Conseqüentemente, poderão passar a identificar as dimensões de calçadas que melhor atendem às operações dos pedestres, redundando em última análise, na implantação de calçadas que proporcione maior satisfação aos usuários.

\subsection{ESTRUTURA DO TEXTO}

A presente pesquisa está estrutura em 8 capítulos. No Capítulo 1, é feita uma breve introdução, salientando a caracterização, justificativa, objetivo e relevância. O Capítulo 2 apresenta uma revisão bibliográfica sobre as questões relacionadas aos deslocamentos dos pedestres, destacando os principais estudos sobre o tema, bem como os critérios que são 
considerados para avaliar o nível de serviço dos espaços destinados a tais usuários. A seguir, no Capítulo 3, é feita a contextualização das condições em que se dão os deslocamentos urbanos na cidade de Boa Vista, sendo apresentados então, os conflitos existentes entre veículos, ciclistas e pedestres nas vias urbanas do referido município.

Após a apresentação deste contexto, mostra-se no Capítulo 4 o método utilizado para alcançar os objetivos desta pesquisa. O Capítulo 5 apresenta um perfil geral sobre os aspectos operacionais das vias estudadas, identificando a influência que o comportamento dos ciclistas, em termos de ocupação das calçadas, provoca na qualidade de deslocamento dos pedestres.

O Capítulo 6 descreve e analisa o processo para a elaboração do conjunto de dados, mostra as variáveis que têm maior influência no nível de satisfação dos pedestres, e apresenta um modelo para dimensionar calçadas. A análise dos resultados encontrados no Capítulo 6, é apresentada no Capítulo 7. Por fim, o Capítulo 8 contém as conclusões e recomendações obtidas nesta pesquisa, além das sugestões para trabalhos futuros. 


\section{Capítulo 2}

\section{CONSIDERAÇÕES SOBRE O TRANSPORTE NÃO MOTORIZADO}

\subsection{INTRODUÇÃO}

Neste capítulo procura-se enfatizar o prejuízo causado à circulação dos transportes não motorizados (TNM), não só em função do aumento da utilização do automóvel no meio urbano, como também pela visão, equivocada, de alguns gestores que priorizam suas ações de governo no sentido de atender e privilegiar a continuidade dos deslocamentos feitos por veículos motorizados e, com isso, deixam de construir em seus municípios uma infraestrutura adequada para a circulação de pedestres e ciclistas.

Mostram-se ainda, vários cuidados e considerações que devem ser tomados para a elaboração de projetos de calçadas para pedestres, considerando a sua largura efetiva, os equipamentos urbanos existentes, o uso do solo, os diferentes tipos de viagens existentes para pedestres. São abordadas os métodos propostos pelo HCM (2000) e por outros estudos, a fim de determinar o nível de serviço das calçadas, apontando as principais variáveis utilizadas por cada uma das abordagens.

Por fim, são feitas algumas considerações sobre a falta de atenção dada aos pedestres no meio urbano e sobre a forma como são medidos os níveis de serviço nas infraestruturas destinadas aos deslocamentos deles. 


\subsection{A INSERÇÃO DOS PEDESTRES NO SISTEMA VIÁRIO URBANO}

A caminhada é o modo mais antigo e natural que existe para a realização de um deslocamento. A maioria das viagens realizadas no meio urbano, por mais que sejam executadas por veículos motorizados, como por exemplo, o automóvel, ou começa ou termina com uma caminhada. Portanto, não se pode estudar um sistema de transporte urbano, desconsiderando a participação do pedestre.

Infelizmente, o que se observa nos dias de hoje é que os gestores municipais se queixam da falta de recursos destinados às obras de infra-estrutura urbana. Entretanto, pode-se observar no Brasil que das obras construídas em uma cidade, poucas ou quase nenhuma dessas, contemplam o deslocamento dos transportes não motorizados. São muito comuns nas cidades as obras de recapeamento viário, implantação de estacionamentos, implantação de novos semáforos, radares, etc., todas voltadas aos veículos motorizados, e indispensáveis; mas relativamente raras são as obras voltadas ao pedestre. Mesmo a parte relativa ao pedestre, nas obras viárias voltadas aos veículos motorizados, costuma ser desprezada ou tratada com pouco cuidado.

Convém destacar aqui que para municípios com pequenas densidades populacionais, a grande área de ruas pavimentadas e estacionamentos acaba impondo à comunidade altos custos, de caráter econômico, social e ambiental. Contrariamente, a melhoria da infraestrutura ao transporte não motorizado, no caso o pedestre, poderia reduzir esses custos (LITMAN, 2003). Segundo o autor, ao mudar a forma de deslocamento, do transporte motorizado para o não motorizado, reduz-se uma variedade de custos externos, que geram aproximadamente em torno de $\$ 0,25$ / milha / veículo no período de menor movimento, e de \$0,50 / milha / veículo no período do pico urbano.

Para (Moudon et al, 2002) as políticas passadas de transporte privilegiaram o uso de veículos em viagens urbanas, causando uma redução das viagens realizadas por pedestres de $10 \%$ para $6 \%$, nos últimos 25 anos. Além disso, o crescente número de veículos acaba 
provocando impactos (congestionamentos, poluição, acidentes, etc.) de diferentes níveis e maneiras nas cidades, trazendo como conseqüência a inibição do deslocamento dos transportes não motorizados.

Evidentemente, a predileção pela continuidade dada ao trânsito de veículos motorizados e a falta de infra-estrutura adequada aos deslocamentos de pedestres, ambos de responsabilidade dos planejadores de transportes, são fatores que contribuem para a geração de conflitos entre veículos e pedestres em áreas urbanas, e são responsáveis por acidentes, na maioria das vezes, de média a alta severidade, inclusive com fatalidades.

Este ônus não deve recair somente sobre as pessoas envolvidas com transportes, pois, como foi dito anteriormente, aos gestores municipais cabe também a conservação de suas cidades que em muitas ocasiões possuem suas calçadas em péssimas condições de uso, apresentando descontinuidades aos deslocamentos dos seus usuários, que se vêem obrigados a utilizar a parte lateral da pista de rolamento e se expor ao trânsito dos veículos motorizados.

Ainda sobre os obstáculos que prejudicam a qualidade das viagens realizadas pelos pedestres, deve-se destacar o mau planejamento da ocupação urbana, uma vez que bancas de jornal, lixeiras, postes, abrigo de ônibus, etc, são exemplos de mobiliários urbanos que diminuem a largura efetiva dos passeios públicos, obrigando as pessoas a disputarem espaços e promovendo conflitos entre si mesmas.

Chilukuri e Virkler (2002) procuraram estudar o comportamento do fluxo de pedestres, quando este chega no sinal de uma interseção, a fim de verificar se ele é influenciado ou não pelo sinal de corrente contrária (sinal dos veículos). Com essa pesquisa identificaram que obstáculos na margem da rua podem atrapalhar o fluxo de pedestres, citando como exemplos: mesas com cadeiras para lanche, estacionamentos de estabelecimentos sobre as calçadas, zoneamento urbano (carga e descarga de veículos) e parada de ônibus. 
A operação de pedestres nas calçadas se dá de forma diferente à da executada pelos veículos nas vias. Estes têm seu fluxo bem canalizado e orientado. Já os transeuntes, principalmente quando em pelotões, não têm os seus fluxos bem orientados e definidos, o que faz necessário que haja um espaço adequado para a sua circulação, livre de obstáculos e que dê opções de caminhamento a esses pedestres, a fim de minimizar os conflitos e melhorar a qualidade das suas operações.

Estudos como o de Daamen e Hoogendoorn, (2003) avaliam o comportamento do fluxo dos pedestres, estudando também as suas características, e constatam a perda de capacidade da via destinada aos pedestres, devido à falta de organização do próprio pelotão de transeuntes quando caminha sobre a calçada.

Já o estudo de Naderi e Raman (2001) procurou detectar o comportamento dos pedestres em ambientes diferentes, sob condições distintas como, por exemplo, o tipo de caminhada: lazer, trabalho, saúde, etc. Nesta pesquisa foi feita a distinção também sobre as caminhadas realizadas em diferentes horas do dia e diferentes estações do ano, pois, a cada uma dessas caminhadas e ambientes envolvidos, os pedestres respondem de forma diferente.

Com o passar do tempo, e com a preocupação dos altos índices de acidentes envolvendo pedestres e veículos, pesquisadores envolvidos da área têm desenvolvido vários trabalhos procurando identificar o comportamento dos pedestres em função da infraestrutura das vias, o perfil de tais usuários, os fatores que mais estimulam o senso de segurança e conforto destes e, as medidas defensivas podem ser adotadas para otimizar a sua circulação.

Dentre esses estudos podem ser citados os trabalhos de Duncan et al. (2002), AlKathairi et al. (2002), Cottreli, W.D. e Pal, D. (2003), Landis et al, (2001), Davis, G.A. (2001) e Fugger Jr et al. (2001).

Mesmo com os inúmeros conflitos existentes entre transportes não motorizados e transportes motorizados nas vias urbanas e, apesar de todos os esforços desenvolvidos na 
área técnica e científica, a fim de diminuir tais situações, a demanda de pedestres nos aglomerados urbanos não pára de crescer, pois, devido ao crescimento desordenado das cidades, muitas pessoas se vêem obrigadas a tomar duas ou mais conduções para chegarem a seus locais de trabalho. Como nem sempre esse custo é suportável, elas procuram novos empregos em locais que possam ser alcançados por simples caminhadas ou pagando apenas uma condução.

\subsection{A INFRA-ESTRUTURA PARA A CIRCULAÇÃO DE PEDESTRES}

Pelo exposto no tópico anterior deste capítulo, percebe-se que atualmente há uma grande preocupação por parte dos pesquisadores e das pessoas envolvidas com a área de transportes, para que os pedestres possam ter maior mobilidade no meio urbano. Desta forma, suas vias devem estar perfeitamente definidas e segregadas dos demais veículos, garantindo-Ihes assim, maior segurança e conforto em seus deslocamentos.

Esse cuidado deve-se ao fato de que tais usuários compreendem em sua categoria, indivíduos com diferentes características, não só em termos de agilidade e percepção como também, alguns podem apresentar limitações físicas como deficiência de locomoção e de visão. Deve-se considerar também, que a dificuldade de locomoção pode acontecer, em alguns momentos, independentemente da condição física do transeunte e sim pela realização, por parte deste, de alguma atividade extra.

Embora haja diferenças nas aptidões físicas, de coordenação motora, percepção e julgamento, os padrões das calçadas, canteiros centrais e áreas de travessia devem atender as necessidades de locomoção de todos os pedestres, independentemente da idade, do grupo social, da aptidão física e da condição do momento.

As calçadas, passeios, ou ainda passeios públicos, como são conhecidos os espaços destinados aos pedestres, devem possuir dimensões necessárias para o deslocamento desses, como também permitir a passagem dos Portadores de Necessidades 
Especiais (PNE) em cadeiras de rodas, e ainda reservar espaço para o plantio de árvores com o intuito de amenizar a caminhada em locais de temperatura elevada - bem como permitir espaço para a instalação de mobiliário urbano. Normalmente, as dimensões de tais facilidades são sugeridas nos manuais de urbanismo e de engenharia de tráfego.

Segundo Gondim (2001), para os projetos de circulação de pedestres é preciso compatibilizar os padrões de dimensionamento dos manuais de urbanismo e de engenharia de tráfego, com os critérios para arborização e as normas da ABNT que definem os espaços necessários para a circulação de deficientes.

\subsubsection{ELEMENTOS DE PROJETO}

Segundo o HCM (2000), quando dois pedestres passam um pelo outro, para que não haja interferência na caminhada de ambos, a largura de calçada destinada a ambos deve ser de 0,8 metros de largura. Quando existirem pedestres que gostam de caminhar juntos, deve-se considerar como largura o espaço de 0,7 metros pra cada um. Espaço lateral menor do que este só ocorre nas horas de maior movimento.

Algumas outras medidas para larguras mínimas recomendáveis para os passeios públicos podem ser encontradas em diferentes manuais de urbanismo e de tráfego, podendo-se citar entre esses o Boletim Técnico № 17 da CET (1978). Tal documento estabelece distâncias médias entre pedestres, a fim de que evitem contatos físicos indesejados durante seus deslocamentos. Essas medidas variam de $1,00 \mathrm{~m}$ a $0,60 \mathrm{~m}$, dependendo do tipo de circulação realizada pelo pedestre (sozinho, lado a lado). Já o manual de urbanismo de Prinz (1980) recomenda outras variações de dimensões para as calçadas, mostradas na tabela abaixo. 
Tabela 2.1 - Dimensões e configurações das calçadas de pedestres.

\begin{tabular}{ccc}
\hline $\begin{array}{c}\text { Número de pedestres em } \\
\text { passagem simultânea }\end{array}$ & Medidas base & $\begin{array}{c}\text { Largura de calçada mínima } \\
\text { recomendável }\end{array}$ \\
\hline 1 pedestre & $0,75 \mathrm{~m}$ & $1,50 \mathrm{~m}$ \\
\hline 2 pedestres & $1,50 \mathrm{~m}$ & $2,25 \mathrm{~m}$ \\
\hline Encontro de 3 pedestres & $2,25 \mathrm{~m}$ & $\geq 2,25 \mathrm{~m}$ \\
\hline Fonte: Prinz (1980) & &
\end{tabular}

Como se vê, medidas relativamente variadas para a largura efetiva de calçadas podem ser encontradas em diferentes manuais. Porém, a aplicação de qualquer uma, em um determinado local, deve considerar o espaço que é usado efetivamente para movimentos de pedestres, descontando a influência da presença de mobiliário urbano (postes, lixeiras, orelhões, etc.), das árvores, das vitrines de lojas, das paredes das edificações e da proximidade do meio fio, pois tais fatores afetam o deslocamento do pedestre e a sua capacidade de circulação na calçada.

O quanto estas pequenas obstruções causam transtornos aos pedestres ainda não foi estudado suficientemente. Porém, um simples ponto de obstrução pode não reduzir por completo a largura efetiva de uma calçada, mas pode ter um efeito negativo sobre o comportamento dos usuários de tal facilidade.

Segundo o HCM (2000), a largura efetiva de uma calçada é o espaço utilizado efetivamente pelo pedestre, podendo ser calculado pela Equação 2.1 e ilustrado na Figura 2.1.

$$
L_{E}=L_{T}-L_{o}
$$

Onde:

$L_{E}=$ largura efetiva da calçada $(m)$,

$\mathrm{L}_{\mathrm{T}}=$ largura total da calçada $(\mathrm{m})$,

$L_{\circ}=$ Soma das distâncias das larguras e recuos das obstruções sobre a calçada (m). 


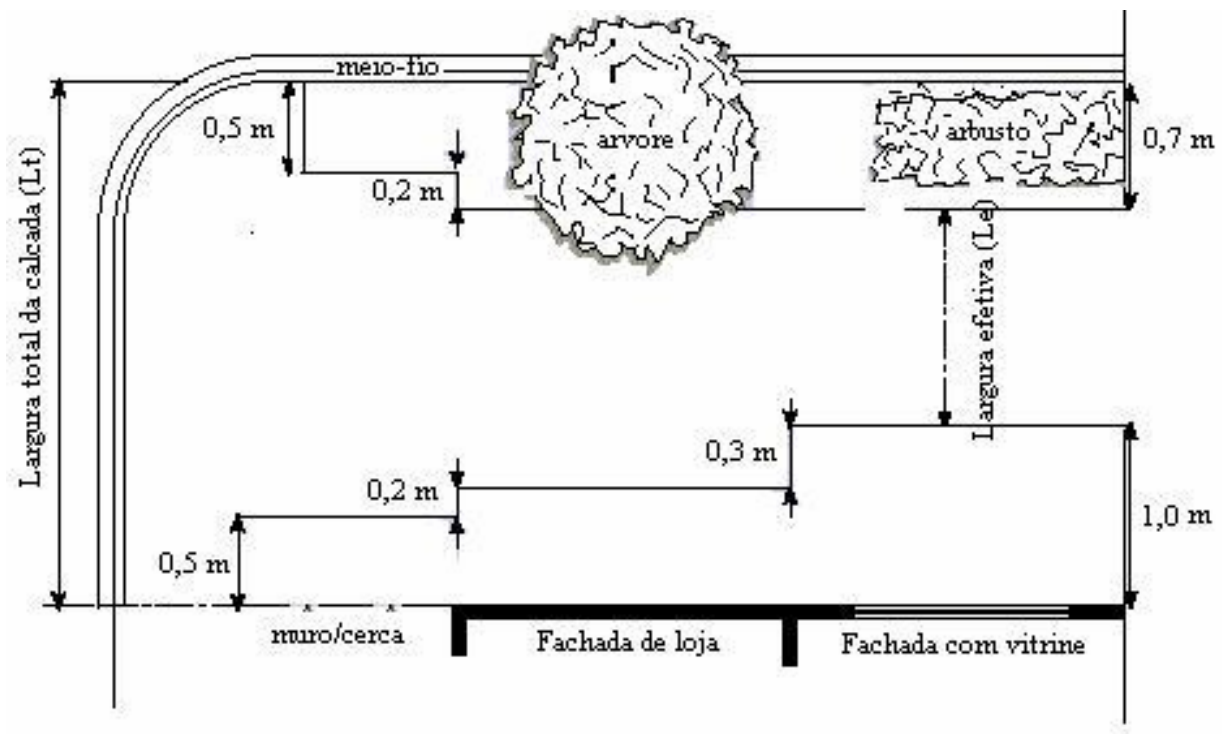

Figura 2.1 - Representação do cálculo da largura efetiva da calçada

Na Tabela 2.2 são apresentados valores que podem ser adotados para projetos de calçadas, segundo o manual citado acima, considerando a zona de influência dos equipamentos urbanos colocados sobre estas, quando não se tem uma avaliação prévia do local.

Tabela 2.2- Valores que podem ser adotados para o cálculo da $L_{E}$ de projeto.

\begin{tabular}{lc}
\hline \multicolumn{1}{c}{ Equipamento Urbano } & Largura aproximada requerida $(\mathrm{m})$ \\
\hline Poste de iluminação & $0,8-1,1$ \\
\hline Postes de sinais de tráfego & $0,9-1,2$ \\
\hline Caixa para alarme de incêndio & $0,8-1,1$ \\
\hline hidrante & $0,8-0,9$ \\
\hline Placas de sinalização & $0,6-0,8$ \\
\hline Parquímetro & 0,6 \\
\hline Caixa de correio & $1,0-1,1$ \\
\hline Orelhão & 1,2 \\
\hline Lixeira & 0,9 \\
\hline Bancos & 1,5 \\
\hline
\end{tabular}

Fonte:HCM (2000)

A seguir, nas tabelas (2.3) e (2.4) são estabelecidos valores para as larguras de influência dos elementos circundantes à calçada, propostos no Boletim Técnico $N^{\circ} 17$ da CET (1978) e no Manual de Urbanismo de Prinz (1980), respectivamente. 
Tabela 2.3 - Valores que podem ser adotados para o cálculo da $L_{E}$ de projeto.

\begin{tabular}{lc}
\hline \multicolumn{1}{c}{ Elementos } & Largura de influência - CET \\
\hline Muro & $0,45 \mathrm{~m}$ \\
\hline Parede de edificação & $0,45 \mathrm{~m}$ \\
\hline Vitrine & $0,45 \mathrm{~m}$ \\
\hline Meio-fio & $0,35 \mathrm{~m}$ \\
\hline
\end{tabular}

Fonte:CET (1978).

Tabela 2.4 - Valores que podem ser adotados para o cálculo da $L_{E}$ de projeto.

\begin{tabular}{ll}
\hline \multicolumn{1}{c}{ Elementos } & Largura de influência - Prinz \\
\hline Poste & $0,75 \mathrm{~m}$ \\
\hline Frente do veículo estacionado perpendicularmente a calçada & $0,75 \mathrm{~m}$ \\
\hline Abertura de porta de veículo estacionado paralelamente & $0,50 \mathrm{~m}$ \\
\hline Presença de vitrines & $1,00 \mathrm{~m}$ \\
\hline Presença de caixas de distribuição & $0,50 \mathrm{~m}$ \\
\hline Parada de ônibus & $2,00 \mathrm{~m}$ \\
\hline Bancos & $1,20 \mathrm{~m}$ \\
\hline Cabines telefônicas & $1,20 \mathrm{~m}$ \\
\hline
\end{tabular}

Fonte:Prinz (1980)

Convém destacar que o plantio de árvores sobre as calçadas pode ter várias utilidades: redução da insolação direta; redução da velocidade dos ventos; redução da poluição atmosférica; redução da poluição sonora; melhoria da paisagem local, "traffic calming" (redução de velocidade dos veículos, melhoria de segurança e qualidade de vida etc) etc.. Tais resultados são benéficos não só para a cidade em questão, como também para os usuários dos transportes não motorizados (TNM). Portanto, o projeto de arborização de uma cidade deve ser considerado na execução da infra-estrutura para a circulação de pedestres.

Moretti (1993) afirma que árvores não devem ser plantadas em calçadas com larguras efetivas menores do que $1,70 \mathrm{~m}$, e procurou correlacionar as dimensões do projeto de calçadas aos portes da vegetação desejada, conforme mostra a tabela (2.5).

Tabela 2.5- Correlação da arborização com a largura da calçada.

\begin{tabular}{ccc}
\hline Largura das calçadas & Porte da árvore & Espaçamento entre plantas adultas \\
\hline$<1,7 \mathrm{~m}$ & Não arborizar & Nenhum \\
\hline $1,7 \mathrm{~m}-2,00 \mathrm{~m}$ & Pequeno $(<5,00 \mathrm{~m})$ & $6,00 \mathrm{~m}-7,00 \mathrm{~m}$ \\
\hline$>2,00 \mathrm{~m}$ & Médio $(5,00 \mathrm{~m}-8,00 \mathrm{~m})$ & $8,00 \mathrm{~m}-10,00 \mathrm{~m}$ \\
\hline
\end{tabular}

Fonte: Moretti (1993). 
Outros estudos definem a distância de separação entre as árvores e a distância destas aos elementos como meio-fio, fachadas, entradas de garagens e estacionamentos, muros, cercas e tráfego Souza (1994) e Puppi (1981).

\subsection{A UTILIZAÇÃO DAS CALÇADAS EM FUNÇÃO DO USO DO SOLO E DO PERFIL DOS PEDESTRES}

Todas as vias de uma cidade devem ter suas larguras efetivas de calçadas bem definidas pelos projetistas ligados à área de transporte, e tais profissionais precisam levar em consideração no cálculo dessas dimensões, não só o perfil dos pedestres que utilizarão as facilidades, como também a demanda, a fim de que as calçadas possam servir os seus usuários com conforto e segurança.

Por este motivo, fica evidente que todo município deve elaborar e respeitar um Plano Diretor que defina, de modo ordenado, os diversos tipos de ocupação do solo, pois esse documento identifica quais os tipos de atividades que serão desenvolvidas em cada área da cidade, como, por exemplo, as áreas comerciais, de serviço, de lazer, etc..

Esta identificação de áreas é importante, pois, existem diferentes grupos de pedestres com objetivos diferentes de caminhadas, que transitam pelas calçadas segundo os motivos de seus deslocamentos. Assim, as pessoas indo para o seu trabalho tendem a deslocar-se mais rápido do que as que estão apenas passeando, e os vendedores, além de caminharem mais lentos que os pedestres normais, ainda limitam a largura efetiva da calçada com os seus tabuleiros e outros equipamentos.

De acordo com o HCM (2000), a velocidade de caminhada dos pedestres é um parâmetro influenciado pela quantidade de idosos. Quando se tem de 0 a $20 \%$ de pedestres idosos, é recomendado o valor de 1,2 m/seg de velocidade para os cálculos das passagens para pedestres. Se o número é maior que $20 \%$ este valor, cai para 1,0 m/seg; a partir daí, 
para cada aumento de $10 \%$ de idosos, sugere-se uma diminuição de $0,1 \mathrm{~m} / \mathrm{seg}$ na velocidade.

Por estes motivos, caso a questão do uso do solo não seja bem definida em um município, diferentes grupos de pedestres poderão vir a ocupar a mesma calçada, causando, assim, um congestionamento a si mesmos, que será refletido no desconforto e na falta de segurança, pois, devido aos objetivos diferentes de caminhadas, alguns pedestres acabam utilizando a lateral da via, ficando expostos à ação do tráfego de veículos.

Gondim (2001) sugere, em termos de legislação urbana, que sejam adotadas algumas medidas mínimas para a infra-estrutura de circulação de pedestres, em função da funcionalidade das vias, do afastamento das edificações e dos equipamentos urbanos. Tais medidas, mostradas na tabela (2.6), devem garantir, segundo a autora, a todos os transeuntes, a segurança e o conforto na via.

Para as referidas dimensões, deve-se garantir que a altura da calçada não ultrapasse $0,15 \mathrm{~m}$ e, quanto aos acessos para portadores de necessidades especiais, deve ser respeitada a declividade máxima de desnível de rampa de 1/10 ou 8,33\%.

Tabela 2.6- Medidas mínimas para calçadas para garantir o conforto e segurança do pedestre

\begin{tabular}{lc}
\hline \multicolumn{1}{c}{ Elementos da infra-estrutura } & Larguras mínimas $(\mathrm{m})$ \\
\hline Calçada em via local & 2,70 \\
\hline Calçada em via coletora & 3,95 \\
\hline Calçada em via arterial & 4,85 \\
\hline Calçada em via arterial com baia de ônibus & 7,85 \\
\hline Canteiro central sem permissão para retorno de veículos & 2,50 \\
\hline $\begin{array}{l}\text { Canteiro central em via litorânea sem permissão para retorno de } \\
\text { veículos }\end{array}$ & 2,80 \\
\hline $\begin{array}{l}\text { Canteiro central com permissão para retorno de veículos de } \\
\text { pequeno porte }\end{array}$ & 5,00 \\
\hline
\end{tabular}

Fonte: Gondim (2001) 


\subsection{MEDIDA DO NÍVEL DE SERVIÇO DAS CALÇADAS}

Conforme apresentado no item 2.4 desta pesquisa, diferentes tipos de pedestres podem caminhar de diversas maneiras sobre as calçadas, dependendo do motivo das viagens, bem como do perfil de cada grupo, e, por este motivo, as facilidades destinadas a tais usuários podem não atingir o seu principal objetivo, que é proporcionar conforto e segurança aos seus deslocamentos.

Por esta razão, pesquisas desenvolvidas com o passar do tempo, procuram identificar e estabelecer os parâmetros que realmente influenciam as operações dos pedestres sobre as calçadas, bem como estabelecer limites, em termos de conforto, desde uma situação desfavorável ao deslocamento até a melhor condição de caminhamento, considerando todos os aspectos, geométricos e operacionais, de uma via. Veja-se, por exemplo, os trabalhos de Fruin (1971), Sarkar (1993) e Khisty (1994).

Segundo o HCM (2000), o Nível de Serviço de uma via, destinada ao fluxo de veículos, é uma medida qualitativa que descreve as condições operacionais dentro de uma corrente de tráfego, baseada em medidas de serviço, como velocidade, tempo de viagem, liberdade para manobras, interrupções no tráfego, conforto e conveniência.

Com relação à determinação do Nível de Serviço para pedestres, o HCM (2000) considera o fluxo destes, analogamente ao de veículos, e utiliza alguns parâmetros como: área de espaço por pedestre, taxas de fluxos, e velocidades, para desenvolver um critério de qualidade de fluxo.

Com isso, o referido manual sugere, para fluxos ininterruptos, que a perda do Nível de Serviço das facilidades destinadas aos pedestres pode ser avaliada pela diminuição da velocidade de caminhada e em termos de espaçamento - que é o inverso da densidade de calçada ( $\mathrm{m}^{2} /$ pedestre). A Figura 2.10 mostra os diferentes Níveis de Serviços para pedestres sugeridos pelo HCM (2000). 
Nível de Serviço A

Área / ped $>5,6 \mathrm{~m}^{2} /$ ped

Taxa de fluxo $\leq 16$ ped $/ \mathrm{min} / \mathrm{m}$

Não há interferência de outros

pedestres

Nível de Serviço B

Área / ped > 3,7-5,6 $\mathrm{m}^{2} /$ ped

Taxa de fluxo $>16-23 \mathrm{ped} / \mathrm{min} / \mathrm{m}$

Liberdade de movimento e escolha da

velocidade de caminhada
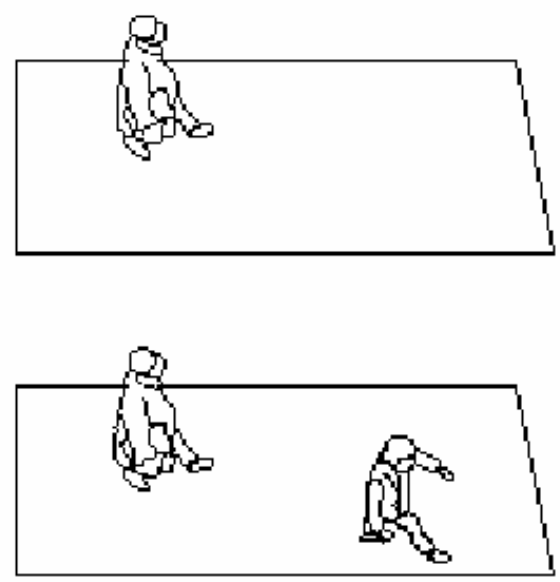

Nível de Serviço C

Área / ped > 2,2-3,7 $\mathrm{m}^{2} /$ ped

Taxa de fluxo $>23-33 \mathrm{ped} / \mathrm{min} / \mathrm{m}$

Velocidades menores, há poucos

conflitos

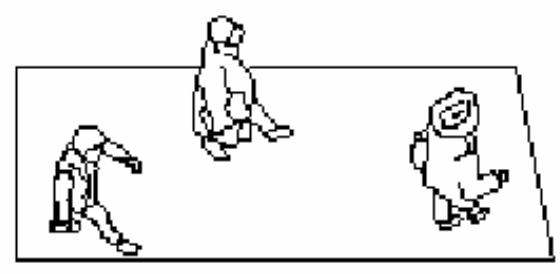

Nível de Serviço D

Área / ped > 1,4-2,2 $\mathrm{m}^{2} /$ ped

Taxa de fluxo $>33-49 \mathrm{ped} / \mathrm{min} / \mathrm{m}$

Movimentos com menor liberdade,

causando mudança na velocidade

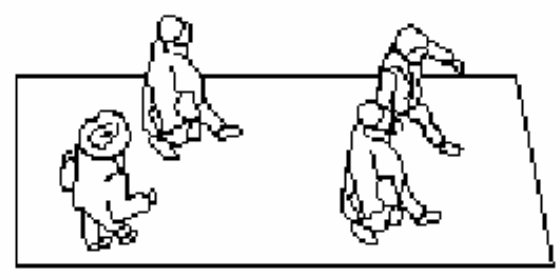

Nível de Serviço E

Área / ped > 0,75-1,4 $\mathrm{m}^{2} /$ ped

Taxa de fluxo $>49-75 \mathrm{ped} / \mathrm{min} / \mathrm{m}$

$O$ volume de pedestres se aproxima da

capacidade limite da calçada; restrições

maiores aos movimentos

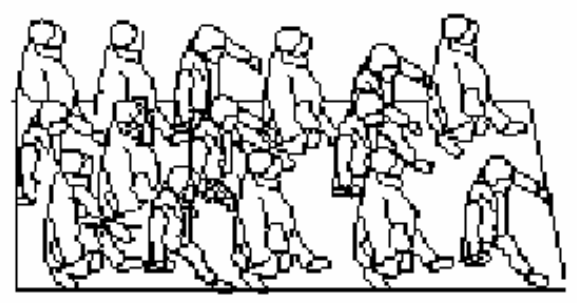

Nível de Serviço $\mathrm{F}$

Área / ped $\leq 0,75 \mathrm{~m}^{2} /$ ped

Taxa de fluxo é variada ped / $\mathrm{min} / \mathrm{m}$;

velocidade de severamente restrita; fluxo

esporádico e instável; congestionamento

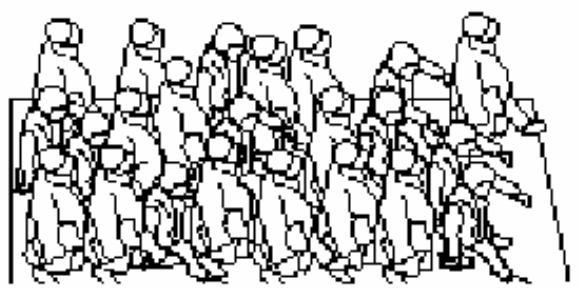

Figura 2.10- Níveis de Serviço segundo o HCM (2000), o espaçamento de pedestres e taxa de fluxo.. 
Observando-se os fatores considerados - fluxo, velocidade e densidade de pedestres - no estudo do HCM (2000) para a definição do nível de serviço de calçadas, pode-se dizer que este fundamentou-se no critério da capacidade. Outros estudos, como o de Fruin (1971) que deu origem ao estudo do manual anteriormente citado; da Companhia Brasileira de Trens Urbanos (CBTU, 1979) e da Empresa Brasileira dos Transportes urbanos (EBTU, 1984), também adotaram o mesmo princípio e, a partir da definição de diferentes áreas ocupadas por pedestres, estabeleceram fronteiras distintas para os níveis de serviço, conforme mostrado nas tabelas a seguir.

Tabela 2.7 - Estudo realizado pelo HCM (2000).

\begin{tabular}{cccc}
\hline Nível de Serviço & $\mathrm{m}^{2} /$ Pedestre & Pedestre/ $\mathrm{m}^{2}$ & Pedestre/Min./m \\
\hline A & 5,6 ou mais & 0,2 ou menos & 16 ou menos \\
\hline B & 3,7 a 5,6 & 0,3 a 0,2 & 23 \\
\hline C & 2,2 a 3,7 & 0,4 a 0,3 & 33 \\
\hline D & 1,4 a 2,2 & 0,7 a 0,4 & 49 \\
\hline E & 0,75 a 1,4 & 1,33 a 0,7 & 75 \\
\hline F & 0,75 ou menos & 1,33 ou mais & Fluxo congestionado \\
\hline
\end{tabular}

Tabela 2.8 - Estudo realizado por Fruin (1971).

\begin{tabular}{cccc}
\hline Nível de Serviço & $\mathrm{m}^{2} /$ Pedestre & Pedestre/ $\mathrm{m}^{2}$ & Pedestre/Min./m \\
\hline A & 3,25 ou mais & 0,31 ou menos & 23 ou menos \\
\hline B & 2,32 a 3,25 & 0,43 a 0,31 & 33 \\
\hline C & 1,39 a 2,32 & 0,72 a 0,43 & 50 \\
\hline D & 0,93 a 1,39 & 1,08 a 0,72 & 66 \\
\hline E & 0,46 a 0,93 & 2,17 a 1,08 & 83 \\
\hline F & 0,460 ou menos & 2,17 ou mais & Fluxo congestionado \\
\hline
\end{tabular}

Tabela 2.9 - Estudo realizado pela CBTU (1979).

\begin{tabular}{cccc}
\hline Nível de Serviço & $\mathrm{m}^{2} /$ Pedestre & Pedestre/ $\mathrm{m}^{2}$ & Pedestre/Min./m \\
\hline A & 3,2 ou mais & 0,3 ou menos & 21 ou menos \\
\hline B & 2,3 a 3,2 & 0,3 a 0,4 & 30 \\
\hline C & 1,4 a 2,3 & 0,4 a 0,7 & 45 \\
\hline D & 0,9 a 1,4 & 0,7 a 1,0 & 60 \\
\hline E & 0,5 a 0,9 & 1,0 a 2,0 & 75 \\
\hline F & 0,5 ou menos & 2,0 ou mais & 75,0 ou mais \\
\hline
\end{tabular}


Tabela 2.10 - Estudo realizado pela EBTU (1984).

\begin{tabular}{cccc}
\hline Nível de Serviço & $\mathrm{m}^{2} /$ Pedestre & Pedestre/ $\mathrm{m}^{2}$ & Pedestre/Min./m \\
\hline $\mathrm{A}$ & 3,72 ou mais & 0,27 ou menos & 20 ou menos \\
\hline $\mathrm{B}$ & 2,23 a 3,72 & 0,27 a 0,45 & 33 \\
\hline $\mathrm{C}$ & 1,48 a 2,23 & 0,45 a 0,68 & 46 \\
\hline $\mathrm{D}$ & 1,02 a 1,48 & 0,68 a 0,98 & 59 \\
\hline $\mathrm{E}$ & 0,56 a 1,02 & 0,98 a 1,79 & 83 \\
\hline $\mathrm{F}$ & 0,5 ou menos & 2,0 ou mais & 83 ou mais \\
\hline
\end{tabular}

Convém destacar, que os estudos acima citados consideraram para a definição de níveis de serviço para calçadas, apenas o fluxo de pedestres, deixando de considerar o ambiente de caminhada, conforme fizeram Sarkar (1993), Khisty (1994), Dixon (1996) e Ferreira e Sanches (2001).

Segundo o manual da CET (1978), pode-se avaliar o nível de serviço das calçadas a partir da qualidade de circulação dos pedestres, conforme mostra a tabela 2.11. Desta forma, foram definidos 6 níveis de serviço, variando em uma escala decrescente de $A$ até $F$, inversamente proporcional à ocupação da calçada, ou seja, o nível de serviço correspondente à circulação do pedestre de forma livre, sem nenhuma interferência de outro pedestre, é o A. Diferentemente, o nível de serviço correspondente à circulação do pedestre com muitos conflitos, em um fluxo congestionado, é o F.

Obviamente, a utilização dos limites propostos pela CET (1978) parece não ser muito recomendável para avaliar o nível de serviço de calçadas, pois, esse método não apresenta uma taxa para ocupação da calçada ou uma taxa de fluxo para pedestres, que possa diferenciar os 6 níveis de serviço propostos, diferentemente do que ocorre em outros métodos como, por exemplo, Fruin (1971); HCM (2000) e EBTU (1984). Portanto, a subjetividade do método proposto pela CET (1978), para avaliar nível de serviço das calçadas, pode conduzir os avaliadores e projetistas a erros grosseiros. 
Tabela 2.11 - Níveis de Serviço X Qualidade da circulação dos pedestres

\begin{tabular}{cc}
\hline Nível de Serviço & Qualidade da circulação \\
\hline A & Circulação livre \\
\hline B & Circulação permitindo ultrapassagens \\
\hline C & Dificuldade com a circulação de sentido oposto \\
\hline D & Circulação densa, com dificuldades e conflitos de ultrapassagem \\
\hline F & Circulação muito densa e freqüentes conflitos \\
\hline
\end{tabular}

Fonte: CET (1978).

Circulação muito densa, própria de multidão

Em seu estudo, Gondim (2001) afirma que os níveis de serviço aceitáveis para o deslocamento de pedestres, segundo o uso do solo e a classe hierárquica da via, são apenas os níveis $\mathrm{A}, \mathrm{B}$ e $\mathrm{C}$, conforme demonstra a tabela 2.12. A autora afirma que a calçada de uma via deve ter $1,50 \mathrm{~m}$ de largura efetiva para que os pedestres possam transitar com segurança e conforto.

Tabela 2.12 - Limites dos Níveis de Serviço.

\begin{tabular}{ccc}
\hline Hierarquia da via & Uso do solo & Níveis de Serviço \\
\hline Local & Residencial & $\mathrm{A}$ \\
& Lazer (comércio e serviços correlatos) & \\
\hline Coletora & Comercial & $\mathrm{A}$ \\
Arterial & Comercial e serviços & B \\
& institucional & C (horários de pico) \\
\hline
\end{tabular}

Fonte: Gondim (2001).

Para a definição desses níveis de serviço, Gondim (2001) baseou-se na condição de circulação definida pela CET (1978), portanto, conforme se disse anteriormente, estes níveis de serviço podem não ser condizentes com a realidade. Outro detalhe a ser observado é que Gondim (2001) não avaliou fluxos de pedestres em seu estudo e as condições operacionais das vias. A autora limitou-se à análise geométrica dos componentes da via, de forma individualizada.

Em seu trabalho, Sisiopiku, Zhang e Virkler (2002) afirmam que, a metodologia proposta pelo HCM (2000) tem a dificuldade de refletir o que é qualidade de serviço sob a ótica do usuário. Esses autores comentam que o pedestre não escolhe a sua rota em função 
do fluxo e da densidade e sim, em função da segurança, atratividade e distância de caminhada.

Sarkar (1993) desenvolveu um método de avaliação qualitativa para determinar o nível de serviço para pedestres e considerou sete parâmetros em sua pesquisa: segurança, seguridade, conforto, conveniência, continuidade, sistema de ligação e atratividade.

O método desenvolvido por Sarkar (1993) teve a finalidade de projetar, com maior segurança, os espaços destinados aos usuários mais vulneráveis de um sistema de transporte urbano, no caso os pedestres, projetando assim, calçadas e interseções que proporcionem maior facilidade aos deslocamentos.

Com seu estudo Sarkar (1993) pretende englobar todos os aspectos que possam influenciar a sensação de segurança dos pedestres. Assim, utiliza alguns parâmetros para avaliar o nível de serviço desses usuários quanto à separação dos indivíduos em relação aos diferentes modos de transportes, e com relação aos aspectos funcionais das calçadas, destinadas aos deslocamentos destes, bem como o meio onde está inserida tal infraestrutura.

Khisty (1994) atribuiu o grau de importância a cada um dos parâmetros definidos por Sarkar e, definiu pesos para cada atributo, conforme a tabela abaixo.

Tabela 2.13 - Medida de desempenho segundo Khisty

\begin{tabular}{ccccc}
\hline Colocação & Medida de desempenho & Média & Desvio padrão & Peso (\%) \\
\hline 1 & Seguridade & 0.354 & 0.120 & 35 \\
\hline 2 & Segurança & 0.241 & 0.108 & 24 \\
\hline 3 & Conforto & 0.101 & 0.032 & 10 \\
\hline 4 & Conveniência & 0.092 & 0.049 & 9 \\
\hline 5 & Atratividade & 0.080 & 0.048 & 8 \\
\hline 6 & Sistema de ligação & 0.071 & 0.029 & 7 \\
\hline 7 & Continuidade & 0.061 & 0.027 & 6 \\
\hline & & 1.000 & & 100 \\
\hline
\end{tabular}

Fonte Khisty (1994) 
Como parte do seu método, Khisty criou uma escala de pontos variando de 0 a 5 em função da porcentagem de satisfação obtida através das opiniões dos pedestres sobre cada parâmetro em questão. A tabela 2.14 ilustra este fato.

Tabela 2.14 - Limites para os Níveis de Serviço.

\begin{tabular}{ccc}
\hline LOS & Padrão & Pontos \\
\hline A & $\geq 85 \%$ satisfeitos & 5 \\
\hline B & $\geq 60$ satisfeitos & 4 \\
\hline C & $\geq 45$ satisfeitos & 3 \\
\hline D & $\geq 30$ satisfeitos & 2 \\
\hline E & $\geq 15$ satisfeitos & 1 \\
\hline F & $<15$ satisfeitos & 0 \\
\hline
\end{tabular}

Fonte: Khisty (1994)

Assim, para cada parâmetro considerado individualmente, obtém-se uma porcentagem de satisfação que corresponde a uma nota da escala de Khisty. Este valor encontrado deve ser multiplicado pelo seu respectivo peso. A somatória de todos os produtos dos parâmetros em questão será o nível de serviço da via, considerando todos os aspectos do ambiente ocupado pelo pedestre. Um exemplo desse cálculo é demonstrado abaixo, onde a nota geral igual a 2,32 indica um nível de serviço ligeiramente superior ao nível D.

Tabela 2.15- Ilustração da medida de cálculo do método de Khisty

\begin{tabular}{cccccc}
\hline Medida de desempenho & \% satisfeito & $\begin{array}{c}\text { Nível de } \\
\text { Serviço }\end{array}$ & Pontos & Peso & Total \\
\hline Atratividade & 21 & $\mathrm{E}$ & 1 & 0,08 & 0,08 \\
\hline Conforto & 22 & $\mathrm{E}$ & 1 & 0,10 & 0,10 \\
\hline Conveniência & 33 & $\mathrm{D}$ & 2 & 0,09 & 0,18 \\
\hline Segurança & 16 & $\mathrm{E}$ & 1 & 0,24 & 0,24 \\
\hline Seguridade & 61 & $\mathrm{~B}$ & 4 & 0,35 & 1,40 \\
\hline Sistema de coerência & 42 & $\mathrm{D}$ & 2 & 0,07 & 0,14 \\
\hline Sistema de continuidade & 48 & $\mathrm{C}$ & 3 & 0,06 & 0,18 \\
\hline Nota geral & & & & & 2,32 \\
\hline
\end{tabular}


Outros parâmetros como a existência de calçadas, continuidade e largura das calçadas, conflitos de pedestres com veículos, amenidades existentes nas calçadas, Nível de Serviço para veículos na via, estado de conservação das calçadas e existência de medidas de moderação do tráfego, foram utilizados por Dixon (1995) para definir o Nível de Serviço das facilidades destinadas aos pedestres. O método proposto pela autora pode ser ilustrado nas tabelas abaixo.

Tabela 2.16 - Ilustração dos parâmetros de pontuação do método de Dixon

\begin{tabular}{clc}
\hline Categoria & \multicolumn{1}{c}{ Critério } & Pontos \\
\hline & Não contínua ou inexistente & 0 \\
Infra-estrutura & Contínua em um lado & 4 \\
disponível para & Contínua em ambos os lados & 6 \\
pedestres & Largura efetiva mínima de 1,53 m e livre de obstáculos & 2 \\
(calçada) & Largura efetiva naior que 1,53 m & 1 \\
(valor máximo=10) & Isolada da via ou alternativa paralela à via & 1 \\
\hline & Entradas de veículos e vias transversais & 1 \\
Conflitos & Atraso nos sinais com tempo para pedestre inferior a 40 s & 0,5 \\
(valor máximo = 4) & Dispositivos de redução de conflitos ou conversões & 0,5 \\
& Largura dos cruzamentos inferiores a 18,3 m & 0,5 \\
& Velocidade dos veículos limitada; máx 56 Km/h & 0,5 \\
\hline Amenidades & Existência de canteiro central ao longo da via & 1 \\
\hline (valor máximo = 2) & Baixa com jardim perto da guia com largura mínima de 1 m & 1 \\
& Arborização & 0,5 \\
\hline Nível de serviço para & Nível de serviço E ou F e 6 faixas ou mais de tráfego & 0,5 \\
veículos motorizados & Nível de serviço D e menos que 6 faixas de tráfego & 0 \\
(valor máximo = 2) & Nível de serviço A, B ou C e menos que 6 faixas de tráfego & 1 \\
\hline Manutenção & Problemas graves ou freqüentes & 2 \\
\hline (valor máximo = 2) & Problemas pequenos ou ocasionais & -1 \\
& Sem problemas & 0 \\
\hline Acessibilidade ao & Não existem facilidades & 2 \\
transporte coletivo & Existem facilidades & 0 \\
(valor máximo = 1) & & 1 \\
\hline Total de pontos & & 21 \\
\hline Fon &
\end{tabular}

Fonte: Dixon (1995)

Tabela 2.17 - Limites dos Níveis de Serviço segundo método de Dixon(1995).

\begin{tabular}{cc}
\hline Nível de Serviço & Pontuação \\
\hline$A$ & $\leq 21 \mathrm{e}>17$ \\
\hline$B$ & $\leq 17 \mathrm{e}>14$ \\
\hline C & $\leq 14 \mathrm{e}>11$ \\
\hline$D$ & $\leq 11 \mathrm{e}>7$ \\
\hline$E$ & $\leq 7 \mathrm{e}>3$ \\
\hline F & $<3$ \\
\hline
\end{tabular}

Fonte: Dixon (1995) 
A partir de um índice de qualidade das calçadas (IQC), Ferreira e Sanches (2001) desenvolveram uma metodologia para avaliar a qualidade de tais infra-estruturas e identificar possíveis pontos de melhorias. O referido índice é definido através de aspectos ambientais percebidos e diferenciados pelos pedestres, e pode ser utilizado para encontrar o nível de serviço das calçadas. São considerados os seguintes fatores: segurança, manutenção, seguridade, largura efetiva e atratividade.

A segurança se refere à possibilidade de conflitos entre pedestres e veículos sobre as calçadas. A manutenção indica os aspectos de qualidade do piso que facilitam ou não o ato de caminhar. A seguridade está relacionada com a vulnerabilidade dos pedestres a assaltos e agressões. A largura efetiva indica a existência de trechos contínuos de calçada com largura suficiente para o fluxo de pedestres. A atratividade está relacionada com os aspectos estéticos e com os atributos visuais do ambiente.

Os estudos de Sarkar (1993), Khisty (1994), Dixon (1995) e Ferreira e Sanches (2001) preocuparam-se em estudar as condições do ambiente de caminhada dos pedestres e, não exatamente a qualidade do deslocamento. Portanto, não foram avaliados os fluxos de pedestres como em Fruin (1971) e HCM (2000), ou seja, os estudos de Sarkar (1993), Khisty (1994), Dixon (1995) e Ferreira e Sanches (2001) não investigaram a percepção que os pedestres sentem, quando estes se deslocam em diferentes fluxos, mas sob o mesmo ambiente de caminhada. Por este motivo, os níveis de serviço apontados por estes métodos podem não refletir bem as condições de caminhada dos pedestres.

O estudo de Landis et al (2001) aponta dois fatores que afetam a sensação de segurança, conforto e comodidade dos pedestres nas vias. Estes podem ser utilizados como medida de desempenho do ambiente destes usuários e podem ser classificados da seguinte maneira: qualidade do ambiente de caminhada e percepção de segurança ou conforto do pedestre em relação ao tráfego veicular. Nesse estudo, com a utilização do programa SAS foi desenvolvido um modelo matemático para a obtenção do nível de serviço dos pedestres. 


$$
\begin{aligned}
\text { PedLOS }=-1.2021 \ln \left(W_{0 i}+W_{1}+f_{p} x \% O S P+f_{b} x W_{b}+f_{S W} x W_{S}\right)+ \\
+0.253 \ln \left(\operatorname{Vol}_{15} / L\right)+0.0005 S P D^{2}+5.3876
\end{aligned}
$$

onde:

PedLOS $\rightarrow$ nível de serviço dos pedestres

$W_{0 i} \rightarrow$ largura da pista externa (pés)

$W_{1} \rightarrow$ largura do acostamento ou da ciclofaixa (pés)

$f_{p} \rightarrow$ coeficiente do efeito de estacionamento na rua $=0,20$

$\% O S P \rightarrow \%$ do segmento com estacionamento na rua

$f_{b} \rightarrow$ coeficiente para área de proteção $=5,37$ para árvores espaçadas de 20 pés

$W_{b} \rightarrow$ largura da área de proteção; distância entre o bordo do pavimento e a calçada (pés)

$f_{S W} \rightarrow$ Coeficiente da presença de calçada $=6-0,3 W_{S}$

$W_{S} \rightarrow$ largura de calçada (pés)

$V l_{15} \rightarrow$ tráfego médio durante período de 15 minutos

$L \rightarrow$ número total de faixas de rolamento

$S P D \rightarrow$ velocidade média do tráfego motorizado $(\mathrm{min} / \mathrm{h})$

O estudo de Landis et al (2001) assemelha-se ao de Sarkar (1993), em ambos, o conforto e segurança dos pedestres é dada em função da separação entre estes usuários e o transporte motorizado. Porém, o estudo de Landis et al (2001), da mesma forma que o estudo de Gondim (2001), avalia os diversos componentes de uma via, de forma isolada e, não avalia as condições de fluxos dos pedestres.

Muraleetharan et al (2004), apresentaram um método para avaliar nível de serviço para pedestres, utilizando a técnica de análise conjunta, a fim de melhor identificar a combinação dos fatores que têm maior influência na caminhada dos pedestres sobre as calçadas e na faixa de travessia. Dessa forma, tais fatores foram identificados e a eles foram atribuídos pesos de acordo com a sua importância individual. No caso das calçadas, a taxa de fluxo foi considerada o fator de maior importância, e no caso de faixas de pedestres, os veículos tiveram maior importância.

Foram estabelecidos cenários com 4 atributos, com três níveis cada, para definir o perfil do ambiente de caminhada dos pedestres sobre as calçadas. Os atributos 
considerados foram os seguintes: largura e separação; obstrução; taxa de fluxo e eventos de bicicletas. A largura e separação está relacionado à segurança dos pedestres em relação aos veículos motorizados. A obstrução está relacionada com os obstáculos que reduzem a largura efetiva da calçada como orelhões, postes, lixeiras, etc.. O fluxo refere-se ao número de pedestres/ minuto/ metro de calçada. Os eventos de bicicletas constituem um atributo que se refere à quantidade de vezes que o pedestre cruza ou é ultrapassado por uma bicicleta, sobre a calçada. A Figura 2.10 mostra os cenários que foram utilizados na pesquisa.

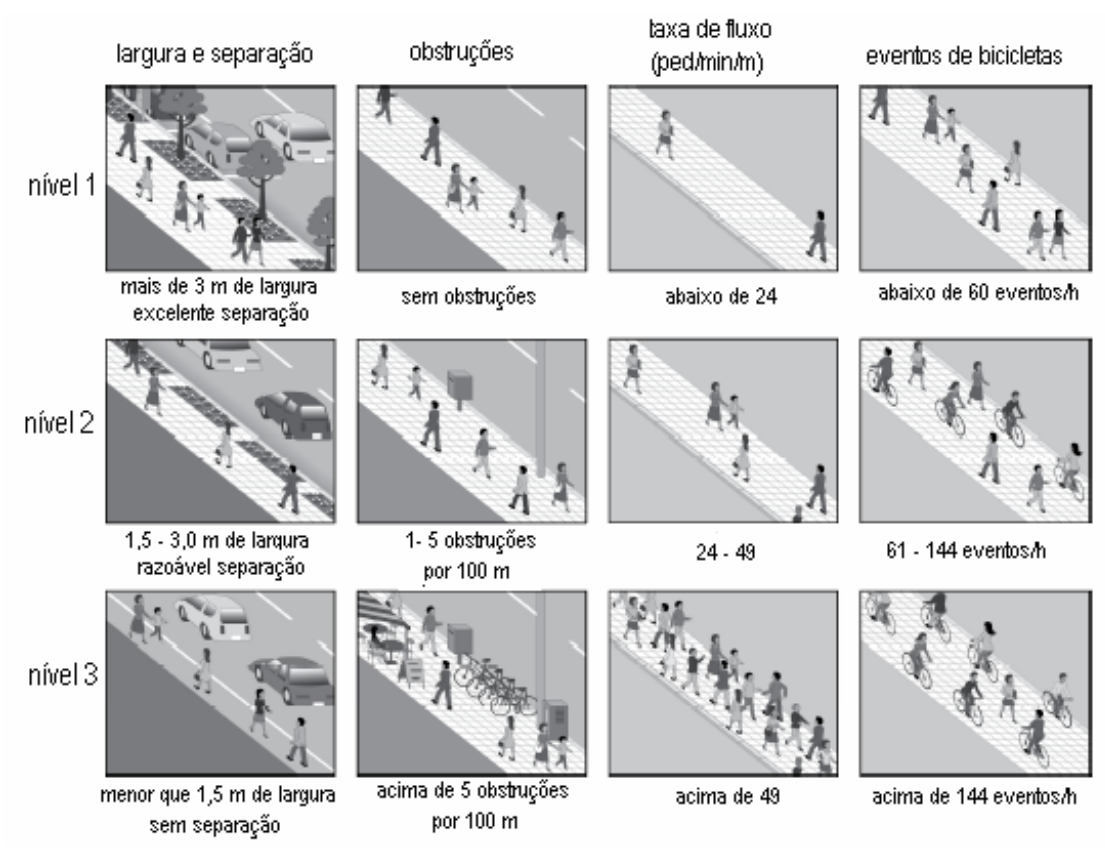

Figura 2.10 - Exemplo dos cenários aplicados no estudo de Muraleetharan et all (2004).

Segundo os autores, o trabalho baseou-se no HCM (2000) e em outros estudos. Entretanto, ao invés de definir níveis de serviço variando de $A$ até $F$, conforme o manual acima citado, definiram-se apenas 3 níveis de serviço, a fim de não confundir as pessoas que responderam à pesquisa. Desta forma, o nível de serviço 1, considerado elevado, equivale aos níveis A e B do HCM (2000); o nível de serviço 2, considerado médio, equivale aos níveis $\mathrm{C}$ e $\mathrm{D}$ e o nível de serviço 3, considerado baixo, equivale aos níveis $\mathrm{E}$ e $\mathrm{F}$. 
Após a definição dos cenários, 11 cartões foram preenchidos, combinando os níveis de cada atributo, e, posteriormente, foram enviados por e-mail para que as pessoas definissem quais dentre as combinações propostas, eram as melhores em ordem crescente, baseadas no princípio do valor da utilidade total.

O estudo concluiu que, em ordem de importância, os fatores que mais influenciam o deslocamento dos pedestres sobre as calçadas são os seguintes: taxa de fluxo e eventos de bicicleta. O estudo concluiu também que obstáculos sobre a calçada têm pouca influência sobre os pedestres.

A equação que representa a estimativa da utilidade total é a seguinte:

$$
U\left(X_{i j}\right)=\sum_{i=1}^{m} \sum_{j=1}^{K_{i}} U_{i j} X_{i j}
$$

$\mathrm{m} \rightarrow$ número de atributos

$\mathrm{U}\left(\mathrm{X}_{\mathrm{ij}}\right) \rightarrow$ utilidade total de uma alternativa

$X_{i j} \rightarrow 1$ se o j-ésimo nível de seus atributos é presente

$\mathrm{K}_{\mathrm{i}} \rightarrow$ número de níveis do atributo $\mathrm{i}$

$\mathrm{U}_{\mathrm{ij}} \rightarrow$ utilidade associada com j-ésimo nível do seu atributo

Muraleetharan et al (2004), em outro estudo, considerando os atributos que têm maior influência no deslocamento dos pedestres e os seus respectivos pesos, definidos anteriormente, avaliaram as calçadas de uma determinada região, e calcularam o valor médio da utilidade para estas, de acordo com a equação 2.3. Seguido a este levantamento, foi realizada uma entrevista com os pedestres no momento em que estes transitavam pelas calçadas avaliadas.

O objetivo da entrevista era que cada pessoa atribuísse um escore para uma determinada calçada, apresentada em foto, de acordo com a maior ou menor facilidade para caminhar sobre a mesma. A nota variaria de 0 (para uma calçada que apresentasse 
condições difíceis de caminhada) até 10 (para uma calçada que apresentasse condições favoráveis de caminhada.

Os resultados das entrevistas foram comparados com os das avaliações das calçadas, feitas anteriormente. A partir dessa comparação, fez-se uma regressão entre os resultados, que foi confirmada pela análise de variância (ANOVA). Após a confirmação, Muraleetharan et all (2004) concluíram que há uma tendência de aumentar a nota atribuída por uma pessoa, a uma calçada, à medida que o valor da utilidade total da calçada cresce. Segundo os autores, a utilidade total é um valor que pode ser explicado pela variabilidade das notas dos pedestres a uma determinada calçada. As figuras abaixo mostram, respectivamente, um exemplo do questionário aplicado aos pedestres e a regressão entre as notas dos pedestres e a utilidade total das calçadas avaliadas, apresentadas no trabalho de Muraleetharan et all (2004).

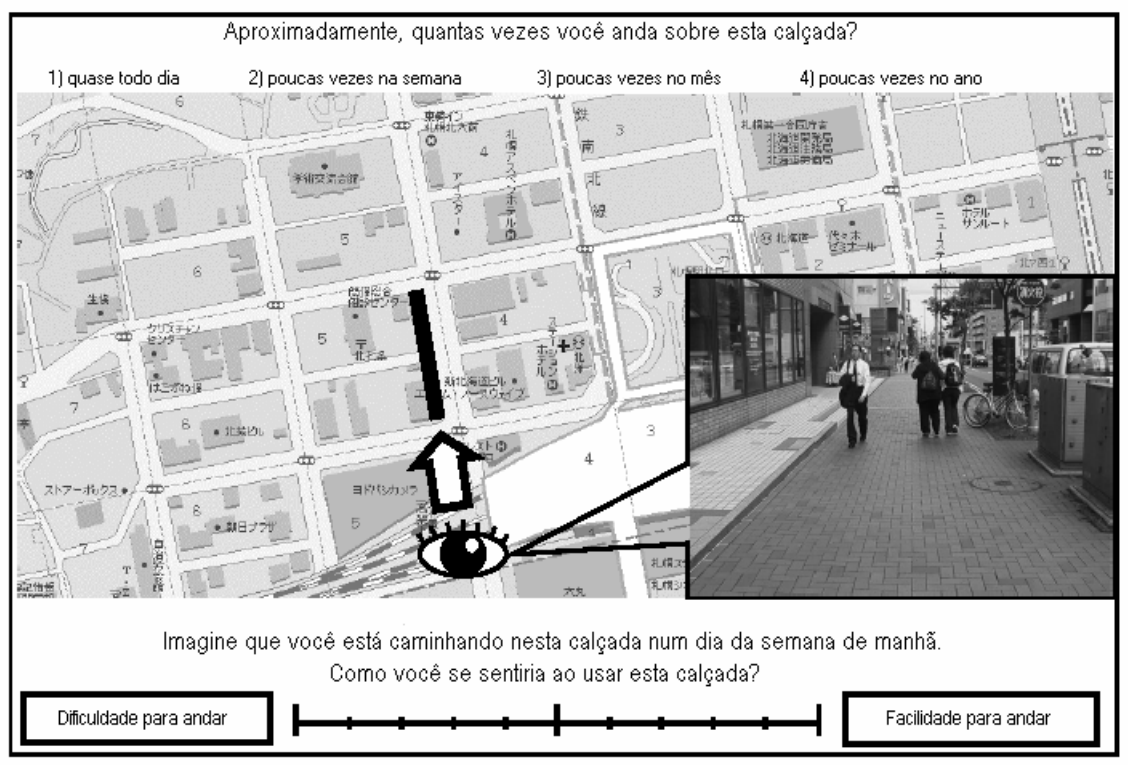

Figura 2.11 - Exemplo do questionário aplicado no estudo de Muraleetharan et all (2004). 


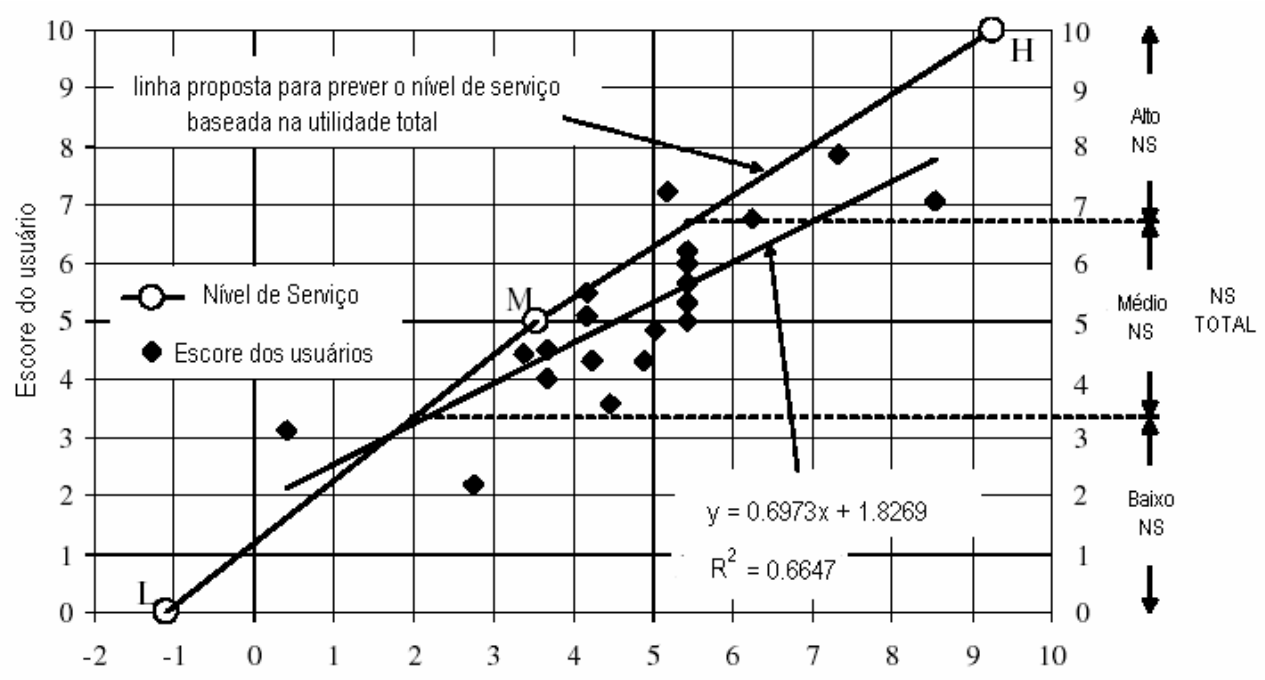

Figura 2.12 - Valores de Utilidade $X$ escores dos pedestres das calçadas de Muraleetharan et all (2004).

Sobre o método proposto por Muraleetharan et all (2004), pode-se dizer que é eficiente para identificar os atributos de maior influência na caminhada dos pedestres sobre as calçadas. Entretanto, a definição de uma hierarquia para tais parâmetros é algo questionável, e acredita-se que a técnica utilizada pelos autores não seja tão satisfatória em função do critério no qual o trabalho se baseia e a forma de como são obtidos os resultados.

O referido trabalho é baseado no HCM (2000), que utiliza o critério da capacidade para definir níveis de serviço distintos para calçadas. Desta forma, as fronteiras para cada nível de serviço são definidas, considerando a redução da velocidade dos pedestres, em função da diminuição do espaço destinado à caminhada. Assim, quanto maior for a ocupação de uma determinada área de calçada, menor será a velocidade dos pedestres e, conseqüentemente, menor será este fluxo na seção considerada.

Convém destacar que a velocidade dos pedestres pode variar de acordo com alguns parâmetros - idade, ocupação, hora do dia, etc - que dependem do perfil de cada um. Então, semelhantemente a uma via para veículos motorizados, pode haver em uma calçada uma concentração relativamente grande de pedestres, porém, todos podem estar desenvolvendo uma velocidade desejada, ou seja, o fluxo pode permanecer contínuo e estável. Desta maneira, como o HCM (2000) considera os aspectos mencionados acima, acredita-se que, ao declarar as suas preferências, sobre uma determinada figura, os 
entrevistados não consigam ter uma percepção condizente com a realidade, em termos de velocidade e concentração das calçadas.

Outro fator a destacar no referido trabalho, que abre margem a questionamentos, é que após a taxa de fluxo dos pedestres, em ordem decrescente de importância, como impedância ao deslocamento dos pedestres, foram apontados os seguintes parâmetros: largura e separação, eventos de bicicletas - esses dois obtiveram, praticamente, a mesma importância - e obstruções. Este último parâmetro, segundo os autores, não influencia muito os deslocamentos dos pedestres.

Porém, a obstrução de uma calçada, por um determinado equipamento urbano (lixeira, orelhão, etc.), reduz a largura efetiva desta reduzindo, consequentemente, o espaço para a passagem dos pedestres e diminuindo a velocidade e o fluxo de tais usuários na calçada considerada, e resultando em menores níveis de serviço para a circulação de pedestres. Assim, afirmar que a obstrução de uma calçada influencia pouco na circulação dos pedestres é algo questionável.

\subsection{COMENTÁRIOS SOBRE OS MÉTODOS UTILIZADOS PARA MEDIR NÍVEL DE SERVIÇO DE CALÇADAS}

Segundo Moretti (1993) os diferentes elementos (calçadas, pista de rolamento, ciclofaixas, etc.), que compõe uma via urbana, possuem funções distintas e interagem na circulação da mesma, gerando conflitos. Obviamente, que a solicitação de cada componente da via será função da condição operacional da mesma.

Até o presente momento, os estudos sobre o nível de serviço de calçadas não consideram esta interação que ocorre na via urbana. Alguns consideram apenas o fluxo, a velocidade e a densidade dos pedestres que passam por uma área pré-definida de calçada. Dentre esses estudos podem ser citados Fruin (1971), HCM (2000), CBTU (1979) e EBTU (1984). Tais estudos definem diferentes níveis de serviço utilizando o critério da capacidade. 
Porém, nenhum desses estudos levou em conta a satisfação dos pedestres em seus deslocamentos.

Outra consideração importante é que, o estudo realizado por Fruin (1971) foi desenvolvido com a intenção de resolver problemas de congestionamento de pedestres em áreas de terminais de transportes, ou seja, não foi realizada uma pesquisa em vias urbanas, considerando a interação dos pedestres com outros usuários das vias. Portanto, foi avaliada apenas a perda da velocidade de caminhada, à medida que aumentava a concentração de pedestres em uma área demarcada no piso dos terminais.

Sarkar (1993) e Khisty (1994) não se ativeram à análise dos aspectos operacionais da via, pois, a avaliação de aspectos como segurança e conflito era determinada independentemente dos fluxos dos transportes motorizados e não motorizados presentes na via. Portanto, o interesse dos referidos trabalhos ficou concentrado na avaliação do ambiente de caminhada dos pedestres, deixando inclusive de considerar o próprio fluxo desses usuários em uma calçada.

Outros estudos desenvolvidos por Dixon (1995) e Ferreira e Sanches (2001) utilizam o critério da condição do ambiente de caminhada dos pedestres para definir níveis de serviço de calçadas.

A partir dos comentários acima, acredita-se que a interação e os conflitos, sugeridos por Moretti (1993), ocorram em uma via urbana. Por este motivo, nota-se que a avaliação do nível de serviço de uma calçada jamais possa ser feita de forma isolada, ou seja, desconsiderando os outros componentes da via em questão e todas as características operacionais da mesma. 


\subsection{CONSIDERAÇÕES FINAIS}

A finalidade deste capítulo foi a de mostrar a preocupação atual de se construir nos meios urbanos, uma infra-estrutura adequada para a circulação de pedestres. Para tanto, há necessidade de avaliar o nível de conforto e segurança dos seus deslocamentos.

Percebe-se que os métodos sugeridos pelo HCM (2000) e por outros estudos citados neste capítulo, apesar de considerarem aspectos qualitativos e quantitativos, inclusive os relacionados à percepção dos pedestres com relação ao meio ambiente, não refletem algumas das condições encontradas em alguns dos municípios brasileiros, ou seja, desconsideram a insatisfação dos pedestres nas calçadas. Essa insatisfação pode ser atribuída aos conflitos com ciclistas, ao fluxo classificado de veículos na via, à pequena largura efetiva das calçadas, à quantidade de pedestres na via (que utilizam ou não as calçadas) e ainda, à quantidade de ciclistas na via (que utilizam ou não as calçadas). 


\section{Capítulo 3}

\section{A CIRCULAÇÃO DOS TRANSPORTES NÃO MOTORIZADOS NA CIDADE DE BOA VISTA X A NOVA POLÍTICA NACIONAL DE TRÂNSITO}

\subsection{INTRODUÇÃO}

Neste capítulo é feita uma breve descrição sobre a cidade de Boa Vista. É mostrado que o referido município apresenta algumas condições favoráveis às viagens realizadas por bicicletas. São mostradas as condições a que estão sujeitos os pedestres, quando realizam seus deslocamentos, na cidade em questão.

É demonstrado também, que a inexistência de uma infra-estrutura adequada aos deslocamentos dos ciclistas, nas vias urbanas (ciclofaixa, ciclovia, etc), obriga estes usuários a deixarem os bordos das vias, passando a ocupar suas calçadas, gerando conflitos com os pedestres e prejudicando o deslocamento desses últimos. Por fim, são apresentadas algumas das principais diretrizes da nova Política Nacional de Trânsito (PNT), e algumas considerações para que Boa Vista possa se enquadrar à mesma.

\subsection{LOCALIZAÇÃO E ASPECTOS GERAIS DA CIDADE DE BOA VISTA}

A cidade de Boa Vista localiza-se na latitude $02^{\circ} 49^{\prime} \mathrm{N}$ e longitude $60^{\circ} 39^{\prime} \mathrm{W}$, à margem direita do Rio Branco. A cidade é pouco mais alta que o Rio Branco que corre 
na cota aproximada de 60 metros (ou mais baixo, na época de seca) acima do nível do mar. Tem, na área urbana, altitudes típicas entre 70 e 85 metros. Isso significa que a cidade é bastante plana, e pouco mais alta que o nível dos rios, facilitando o deslocamento a pé ou de bicicleta, e dificultando a boa drenagem. O Rio Branco, na região do município e imediações, deixa várias praias fluviais apreciadas para o lazer.

É a capital do estado de Roraima e tem uma população de cerca de 210 mil habitantes, segundo a contagem populacional realizada pelo IBGE em 2000.

Com relação ao fator clima, pode-se dizer que existem dois períodos bem definidos. O período de chuvas (monções) vai de maio a setembro e o da seca de outubro a abril (tecnicamente, inverno, pois Boa Vista está no Hemisfério Norte), ambos, porém, com temperaturas elevadas. O clima pode ser descrito como tropical úmido, sem estação extremamente seca, mas com precipitação abaixo de $60 \mathrm{~mm}$ no mês mais seco e temperatura média mensal das mínimas diárias acima de $18^{\circ} \mathrm{C}$. Isso permite classificar o clima, segundo Koeppen, no tipo A, subtipo AW, ou seja, quente e úmido, com uma estação chuvosa no verão, e uma estação seca. A precipitação anual é de cerca de 1.780 milímetros de chuva.

Segundo dados fornecidos pela Delegacia Federal de Agricultura (DFA) referentes ao período de 1998 a 2002, a média, em 5 anos, das temperaturas máximas anuais é $36^{\circ} \mathrm{C}$ e a média das temperaturas mínimas anuais é $21^{\circ} \mathrm{C}$. A temperatura média diária representativa desses 5 anos é perto de $28^{\circ} \mathrm{C}$. A média da umidade relativa do ar é de $74 \%$.

Durante os mesmos 5 anos, registrou-se para o número de ocorrências de chuvas o valor de 123 chuvas/ano, com uma quantidade média de 14,5 mm/precipitação. Convém destacar que as precipitações locais são muito irregulares e apresentam grandes oscilações, em termos de quantidade de chuva (mm), para um mesmo mês, em anos consecutivos. O mês das maiores precipitações é o de junho, fim da primavera e início do verão. 
Apesar de todos os aspectos citados acima, percebe-se que existe um número relativamente alto de usuários não motorizados realizando suas viagens utilitárias, a pé ou de bicicletas, pelas vias e calçadas da cidade, contrariando alguns limites sugeridos pela bibliografia existente sobre o assunto.

De acordo com estudo realizado pela Federal Highway Administration (FHWA, 1992), a cidade considerada ideal para o ciclismo é aquela que tem a média das temperaturas máximas entre $18^{\circ} \mathrm{C}$ e $28^{\circ} \mathrm{C}$ e menos de 60 dias de precipitação mensurável durante 0 ano. Logo, constata-se que estes intervalos não estão enquadrados à realidade de Boa Vista.

Entretanto, existem dois fatores favoráveis aos deslocamentos dos usuários não motorizados: as distâncias curtas de viagens e a topografia plana do local. Tais fatores, aliados às condições sócio-econômicas da maior parte da população, tornamse com certeza os parâmetros condicionantes destas viagens, superando o clima nada ameno do local.

\subsection{AS CONDIÇÕES DE CAMINHADA DOS PEDESTRES EM BOA VISTA}

No capítulo 2 foram apresentados os principais parâmetros que devem ser considerados, em todo processo de implantação, desde o planejamento até a execução, de uma infra-estrutura destinada à circulação de pedestres. Portanto, aqui serão feitas apenas algumas descrições sobre a maneira com que se deslocam os pedestres nas vias urbanas de Boa Vista.

Percebe-se que em muitas vias, inclusive em algumas arteriais, não existem calçadas laterais destinadas aos deslocamentos de pedestres. Em alguns casos, quando elas existem, notam-se algumas irregularidades ao longo dessas, fazendo 
com que o pedestre acabe procurando o acostamento ou o meio-fio da pista de rolamento. Tal situação pode ser observada na figura a seguir.

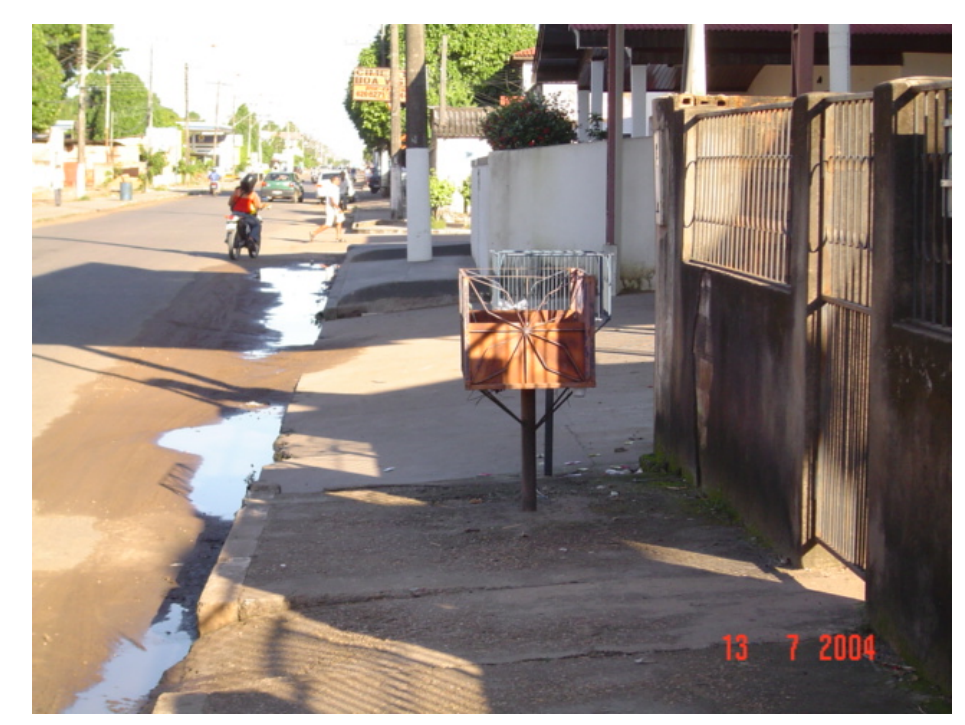

Figura 3.1- Exemplo de calçada prejudicial ao deslocamento dos pedestres

Outro aspecto prejudicial ao pedestre é a distância existente entre paradas de ônibus, distando umas das outras de até 400 metros, que representa um nível regular de acessibilidade, porém, esta distância em Boa Vista muitas vezes é percorrida sem qualquer infra-estrutura construída para o usuário caminhar.

Deve-se considerar também o elevado tempo de espera nas paradas de ônibus, que na maioria das vezes não possuem qualquer tipo de acomodação ou abrigo para o usuário. Assim, são provocados conflitos entre as pessoas que aguardam o ônibus e o fluxo de pedestres sobre a calçada.

Cabe ainda ressaltar que nos períodos de chuva mais intensos, entre os meses de maio a agosto, são verificados muitos alagamentos nas vias da cidade devido à falta de drenagem. Tal fato acaba prejudicando também a mobilidade dos usuários não motorizados, que procuram o ponto mais adequado para fazer uma travessia, aumentando o seu tempo e distância de caminhada. 


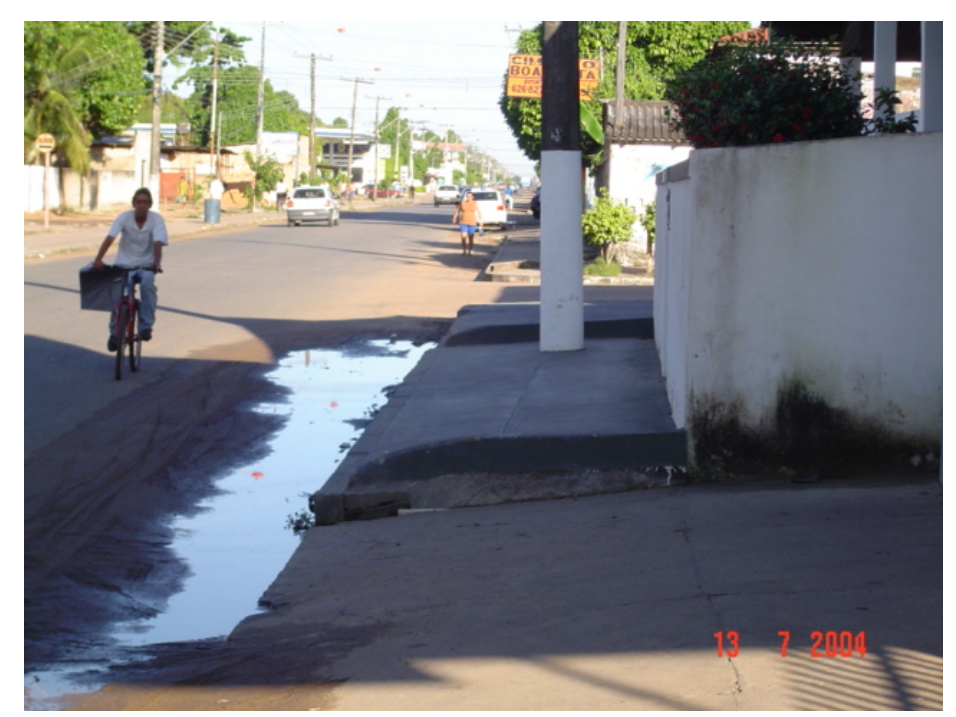

Figura 3.2- Falta de drenagem afastando o ciclista para o meio da rua

\subsection{A INFLUÊNCIA DOS CICLISTAS NA CIRCULAÇÃO URBANA DE BOA VISTA}

Segundo a Empresa Brasileira de Planejamento de Transportes (GEIPOT, 2001), pode-se afirmar com segurança que a bicicleta é o veículo individual mais utilizado nos pequenos e médios centros do país em função de duas razões: nesses locais, os transportes coletivos, com raras exceções, não se viabilizam e os automóveis só estão ao alcance de uma minoria da sociedade, devido a atual concentração de renda no Brasil.

Entretanto, como em boa parte dos municípios brasileiros, a cidade de Boa Vista não demonstra, no seu plano diretor, uma política voltada aos interesses dos transportes não motorizados, preterindo estes por aqueles que integram o fluxo de veículos automotores. Sendo assim, percebe-se que há pouca ou quase nenhuma infra-estrutura para que sejam realizados deslocamentos não motorizados no município, com qualidade e segurança. Tal fato contribui para que haja alguns acidentes em Boa Vista envolvendo ciclistas e pedestres. 
Davis (1997) afirmou que as características da via e seu dimensionamento vão ter influência sobre a velocidade a ser adotada para os veículos motorizados e, portanto, sobre a segurança dos transeuntes e bicicletas, já que a vulnerabilidade de pedestres e ciclistas é diretamente proporcional a esta velocidade. Segundo o autor, ciclistas e pedestres são feridos menos seriamente quando o veículo está se movimentando até $30 \mathrm{~km} / \mathrm{h}$ no momento do impacto. Se a velocidade está entre $30 \mathrm{~km}$ e $55 \mathrm{~km}$ os ferimentos são geralmente sérios e acima de $55 \mathrm{~km}$ o impacto põe em perigo a vida de ciclistas e pedestres.

Em outra pesquisa Davis (2001) mostrou a necessidade de avaliar a interação de pedestres e veículos que operam em uma via, e estabeleceu novamente relações entre a velocidade de impacto dos veículos e a severidade dos danos causados aos pedestres. Nesta pesquisa o autor argumenta que a velocidade de veículos, em vias residenciais, deveria ser de $40 \mathrm{Km} / \mathrm{h}$ e afirma que velocidades de veículos entre 70 e $75 \mathrm{Km} / \mathrm{h}$ podem provocar acidentes fatais aos pedestres.

De acordo com dados coletados pelo DETRAN-RR, em Boa Vista, no mês de setembro de 2004 houve 954 acidentes de trânsito com vítimas não fatais. Deste número total verificou-se que $6 \%$ dos acidentados pertenciam à classe dos pedestres e $13 \%$ à dos ciclistas. Para o mesmo período de contagem, computou-se um total de 43 acidentes com vítimas fatais onde $16 \%$ dos acidentados eram pedestres e $25 \%$ eram ciclistas. De janeiro a março de 2005 foram computados 256 acidentes de trânsito na cidade de Boa Vista, segundo o DETRAN-RR, deste total $5 \%$ das vítimas pertenciam à classe dos pedestres e $13 \%$ à classe dos ciclistas.

Obviamente, uma parcela dos resultados apresentados acima está diretamente ligada a pouca atenção dispensada aos transportes não motorizados, por parte dos planejadores urbanos, pois a falta de um espaço específico para ciclistas faz com que os eles tenham que circular pelos bordos das vias, deixando-os, portanto, expostos e vulneráveis à ação dos veículos motorizados, conforme demonstram as figuras abaixo. 


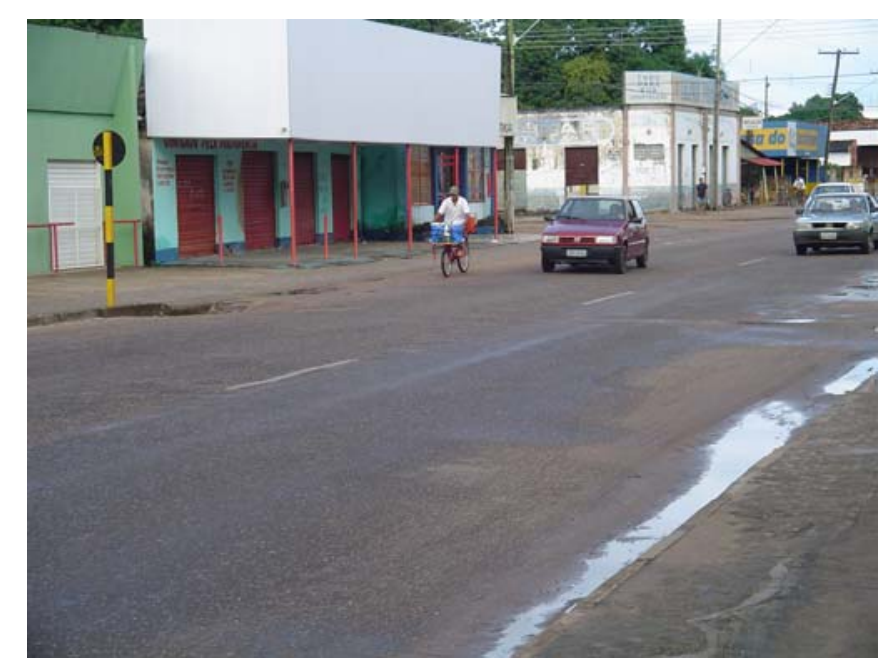

Figura 3.3- Deslocamento do ciclista pelo bordo da Av. General Atayde Teive

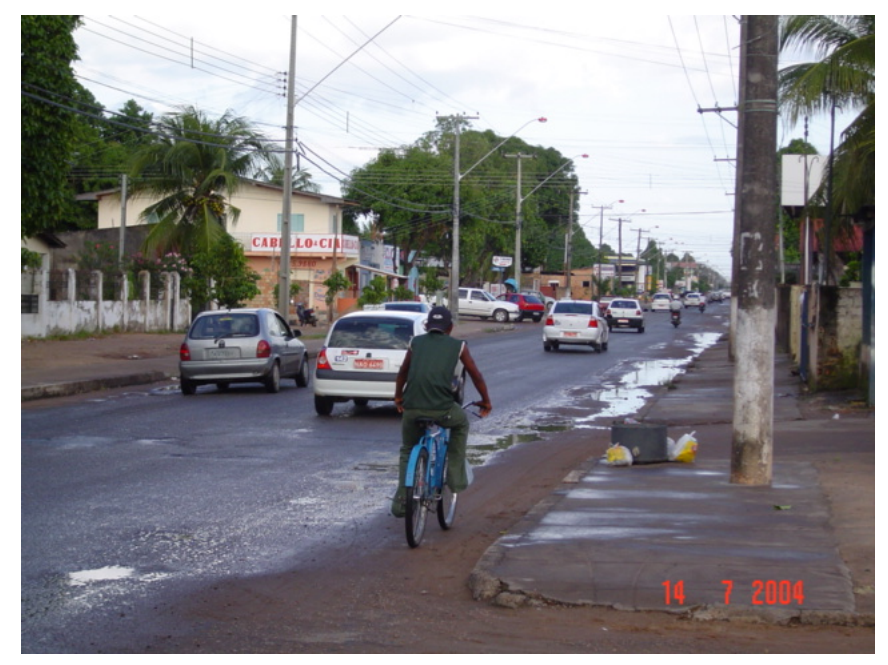

Figura 3.4- Deslocamento do ciclista pelo bordo da Av. General Mário Homem de Melo

A situação apresentada, nas figuras 3.3 e 3.4, não é apenas desfavorável para os ciclistas, pois à medida que o tráfego motorizado de uma via aumenta há uma tendência dos ciclistas em ocuparem as calçadas desta via, deixando os bordos da mesma. Tal fato pode ser constatado nos gráficos das figuras 3.5 e 3.6 a seguir, construídos a partir de contagens realizadas em algumas vias do município de Boa Vista.

Na figura 3.5 é apresentada uma comparação do tráfego médio de veículos motorizados, que circulam pelas vias, nos períodos de pico e entre-picos, para um 
número total de 24 observações, em termos de tempo, divididas em intervalos de 5 minutos cada. Assim, para o período de tempo que englobava o pico foram feitas contagens de 6:30 h até às 8:30 h, e para o período entre-picos as contagens foram de 8:35 h até às 10:35 h. Na legenda da figura 3.5, o termo "tráfego P" significa tráfego de veículos motorizados no período de pico e o termo "tráfego EP" é referente ao mesmo tráfego, porém, no período entre-picos.

\section{Com paração do tráfego motorizado nos períodos de contagem}

(Pico e entre-picos)

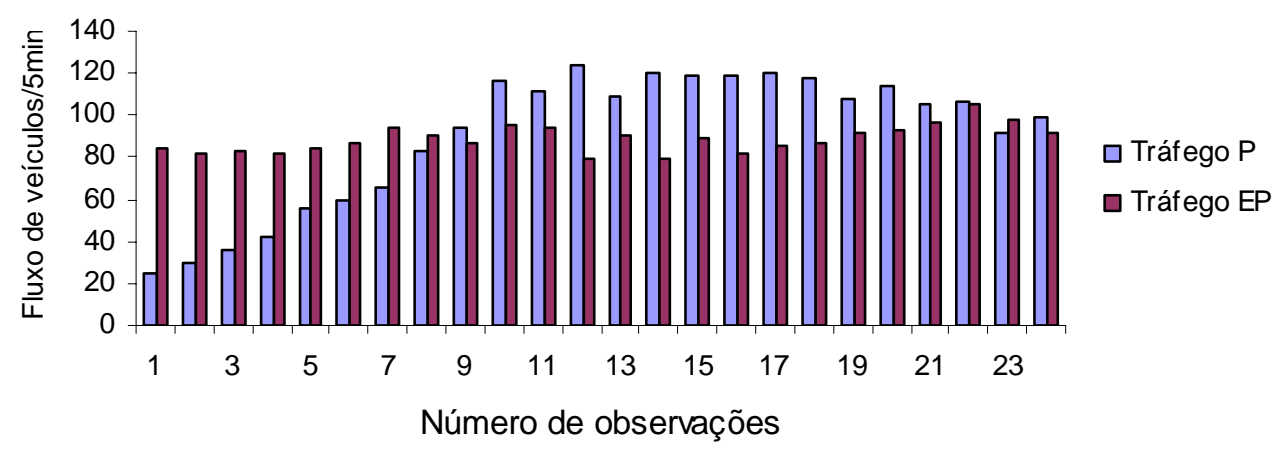

Figura 3.5- Gráfico que representa a média do tráfego de veículos motorizados no período de pico e entre-pico.

Na figura 3.6 é apresentada uma comparação do fluxo médio de ciclistas, que circulam pelas calçadas das vias, nos períodos de pico e entre-picos, conforme descrito anteriormente para a figura 3.5. Na legenda da figura 3.6, o termo "Ciclcal P" significa fluxo de ciclistas sobre a calçada da via no período de pico e o termo "Ciclcal EP" é referente ao mesmo fluxo, porém, no período entre-picos. 


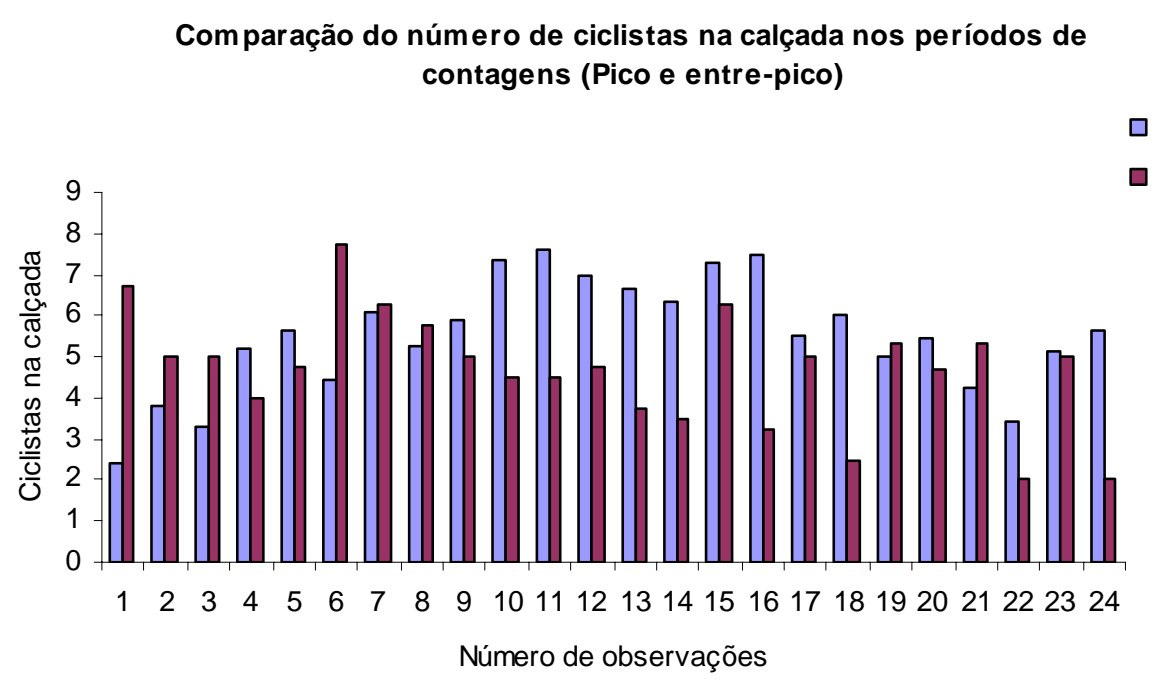

Figura 3.6- Gráfico que representa a média dos ciclistas nas calçadas no período de pico e entre-pico.

Comparando-se as figuras 3.5 e 3.6 percebe-se que há um sincronismo entre os gráficos, pois independentemente do período de análise (pico / entre-picos) em questão, bem como do fluxo, pode-se notar que havendo um aumento de tráfego motorizado na via, haverá também maiores números de ciclistas nas calçadas. A tabela abaixo reforça a situação descrita.

Tabela 3.1- Distribuição do número de ciclistas na via, considerando os dois períodos de contagem.

\begin{tabular}{ccc}
\hline Período & Pico & Entre-picos \\
\hline Ciclcal & 132 & 113 \\
\hline Ciclfora & 209 & 153 \\
\hline Cicltotal & 341 & 266 \\
\hline \% Ciclcal & 39 & 42 \\
\hline
\end{tabular}

Na tabela 3.1 são apresentados o número de ciclistas sobre as calçadas (Ciclcal), o número de ciclistas nos bordos da via - fora das calçadas - (Ciclfora), o número total de ciclistas na via (Cicltotal), e a porcentagem de ciclistas sobre as calçadas. Todos os dados foram apresentados considerando os períodos de pico e entre-picos. O tráfego médio de veículos motorizados para toda a extensão de tempo, 
que englobou o período de pico, foi de 2171 veículos, e para o período entre-picos foi de 2134 veículos.

Pela tabela 3.1 percebe-se que, em relação ao número total de ciclistas, há uma porcentagem significativa destes usuários que ocupa as calçadas da via. Em conseqüência disso, os pedestres se vêem obrigados a disputar os espaços, destinados aos seus deslocamentos, com os ciclistas. Tal situação encontra-se evidenciada nas figuras a seguir.

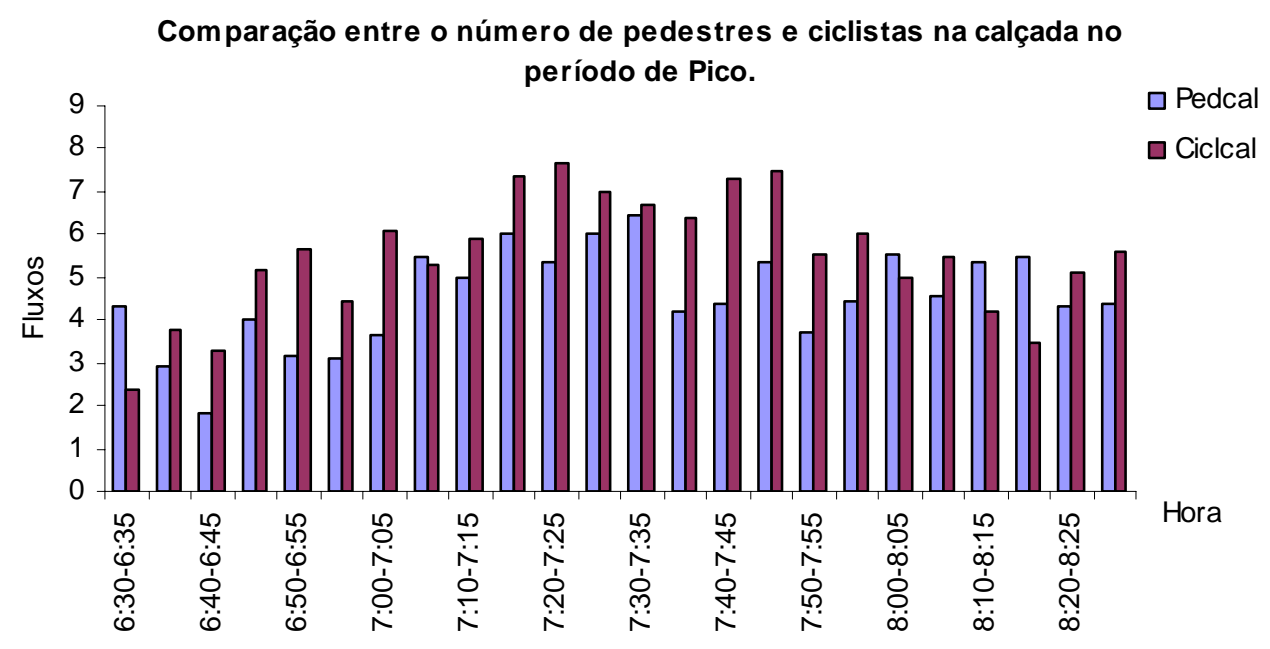

Figura 3.7- Gráfico que representa a média dos pedestres e ciclistas nas calçadas no período de pico.

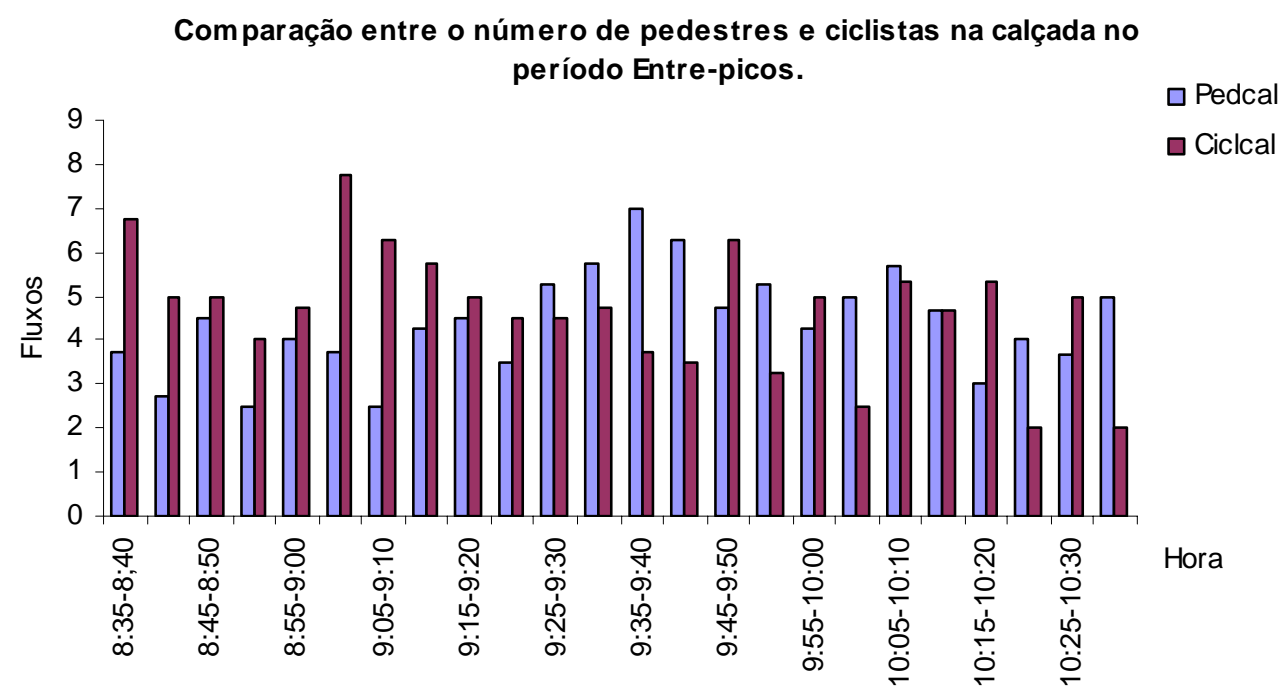

Figura 3.8 - Gráfico que representa a média dos pedestres e ciclistas nas calçadas no período de entre-picos. 
As figuras 3.7 e 3.8 mostram como é significante a ocupação das calçadas por parte dos ciclistas, para os períodos de pico e entre-picos. Ainda que seja considerado o fator segurança dos ciclistas, sabe-se que as calçadas não são destinadas à circulação desses usuários, pois, tal fato, além de contrariar o Código de Trânsito Brasileiro (CTB), causa uma impedância à caminhada dos pedestres. Em alguns casos os ciclistas provocam pequenos acidentes com os pedestres. A tabela abaixo mostra a porcentagem de ocupação das calçadas, por pedestres e ciclistas, para ambos os períodos de contagem.

Tabela 3.2 - Distribuição do número de ciclistas e pedestres na calçada da via, considerando os dois períodos de contagem.

\begin{tabular}{ccc}
\hline Período & Pico & Entre-picos \\
\hline Pedcal & 109 & 106 \\
\hline Ciclcal & 132 & 113 \\
\hline Pedcal + Ciclcal & 241 & 219 \\
\hline$\%$ Pedcal & 45 & 48 \\
\hline \% Ciclcal & 55 & 52 \\
\hline
\end{tabular}

Além de o tráfego motorizado causar o deslocamento dos ciclistas para as calçadas de uma via, pode-se dizer que quanto maior for o número total de ciclistas em uma via, maior será a tendência destes ocuparem as calçadas, conforme demonstram as figuras abaixo. 


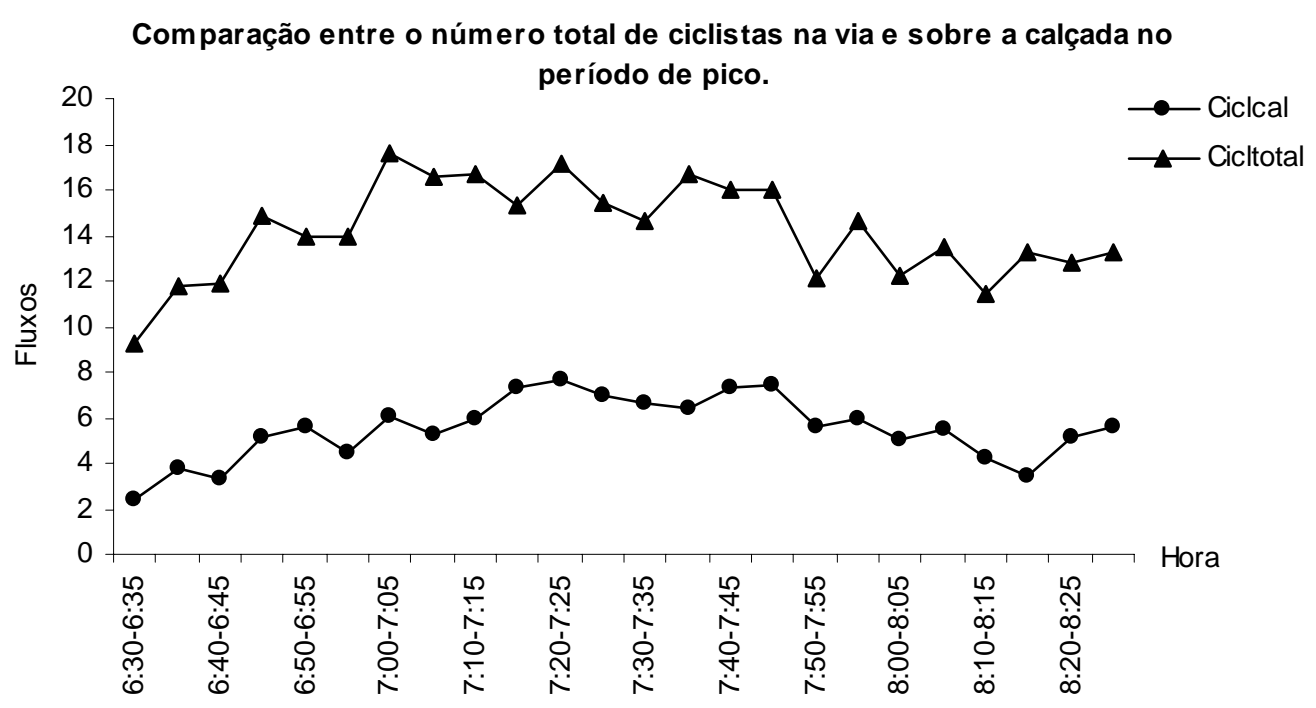

Figura 3.9 - Gráfico comparativo do número total de ciclistas na via com o número de ciclistas sobre as calçadas no período de pico.

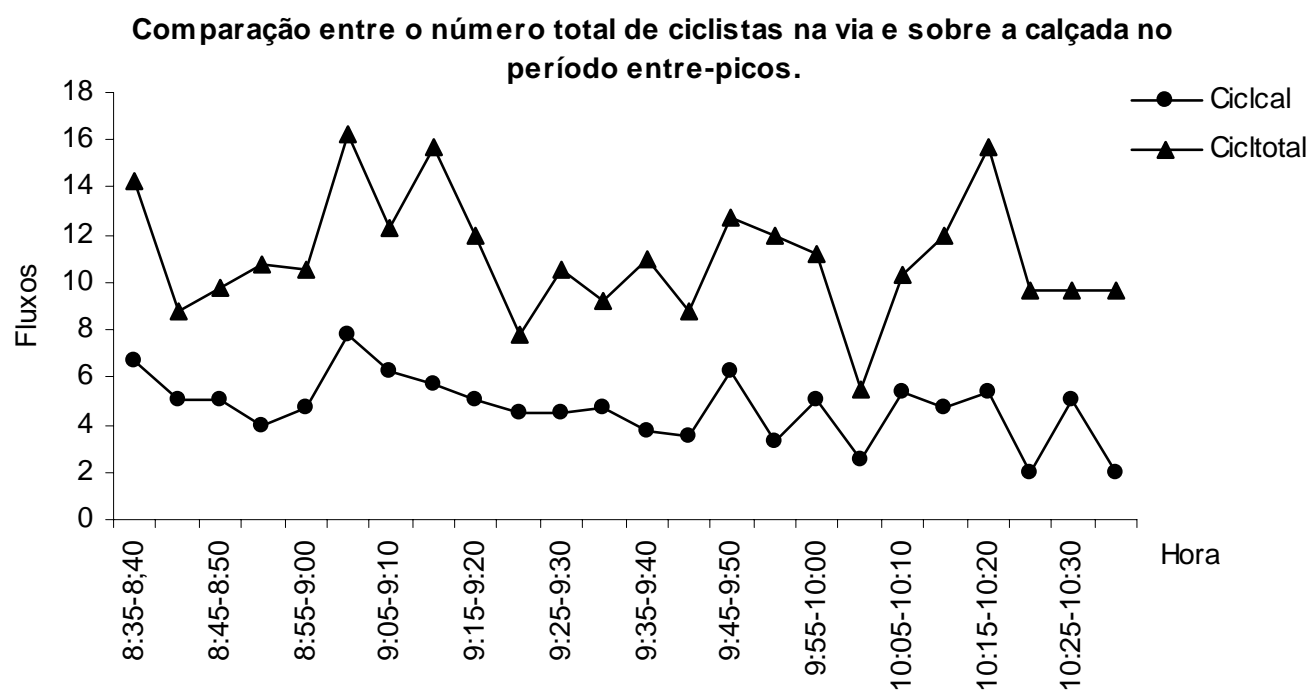

Figura 3.10 - Gráfico comparativo do número total de ciclistas na via com o número de ciclistas sobre as calçadas no período de pico.

Stinson e Bhat (2003) concluíram que os ciclistas preferem andar em vias com baixo volume de tráfego motorizado. Além disso, tais usuários preferem rotas parcialmente ou totalmente separadas dos veículos.

Dill e Carr (2003) realizaram uma pesquisa com o intuito de identificar as variáveis de maior importância para o incentivo do transporte por bicicleta. Dentre as variáveis estudadas estavam renda per capta, preço da gasolina e a avaliação do 
trânsito. Entretanto, os resultados da pesquisa apontam a presença de uma infraestrutura, destinada especificamente aos ciclistas, como fator mais importante para o surgimento dessa classe nas vias urbanas.

McDonald e Burns (2001) comparam três rotas diferentes escolhidas por ciclistas em seus deslocamentos diários de casa para o trabalho, e procuram correlacionar as escolhas destes usuários com as infra-estuturas destinadas a eles, em cada rota. Com isso, os autores perceberam que muitos ciclistas estão dispostos a percorrer grandes distâncias, a fim de encontrar vias com espaços específicos para os seus deslocamentos, e, que algumas pessoas já não optam por bicicletas se tiverem que fazer seus deslocamentos na mesma via que os automóveis.

Na mesma pesquisa McDonald e Burns (2001) comentam que profissionais de transportes envolvidos com a questão dos ciclistas, concluem que as infra-estruturas existentes para esses usuários são os locais mais seguros para os seus deslocamentos, diferentemente da idéia popular de que os ciclistas podem andar com segurança em calçadas ou em caminhos compartilhados. Os autores afirmam que apesar da importância de se planejar ciclovias ou ciclofaixas nas vias urbanas, cada cidade deve fazer um estudo particular de suas rotas e da sua população de ciclistas, a fim de que seus projetos possam definir a flexibilidade, a capacidade e a utilidade de tais facilidades.

Convém destacar que além do prejuízo causado à circulação dos pedestres, a presença de ciclistas sobre as calçadas provoca a evasão dos pedestres para os bordos da via, deixando-os expostos ao tráfego motorizado. As duas situações acontecem com muita freqüência em Boa Vista e são ilustradas a seguir. 


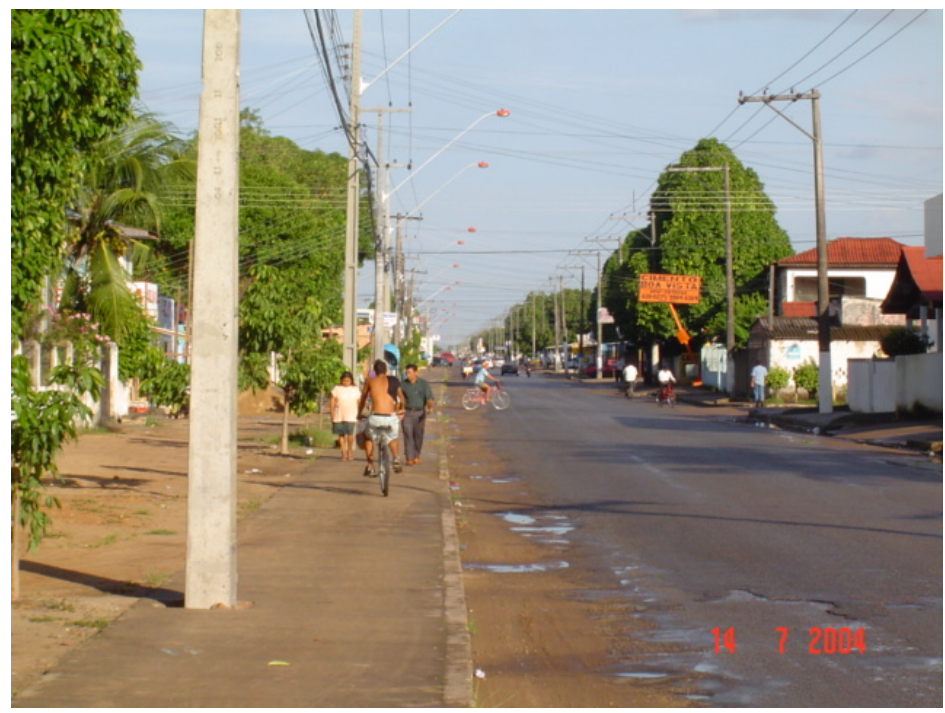

Figura 3.11 - Conflito entre ciclistas e pedestres sobre a calçada

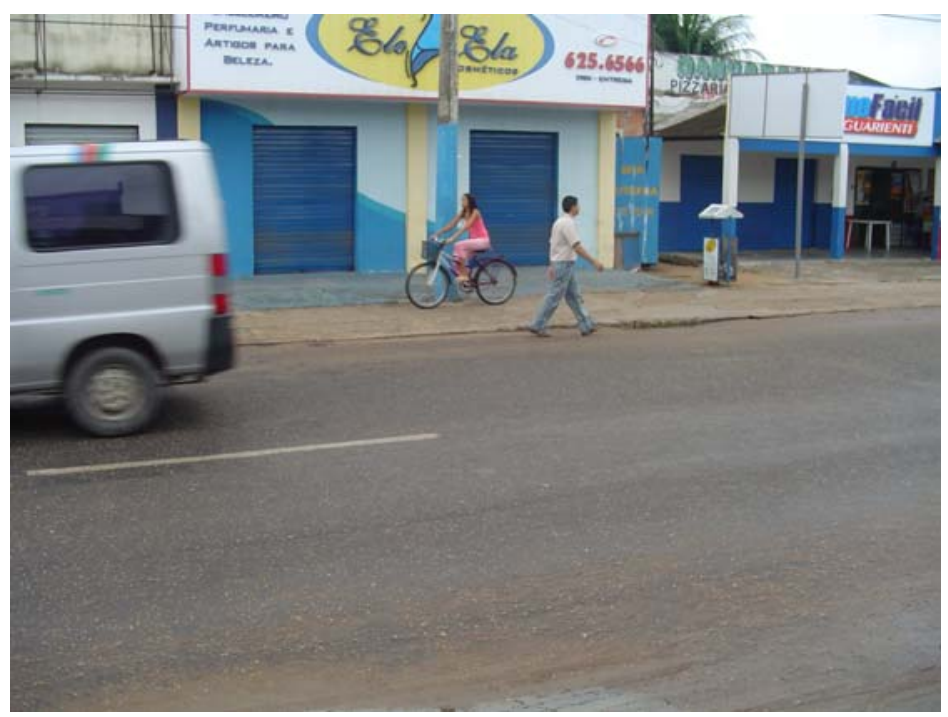

Figura 3.12 - Evasão do pedestre da calçada para o bordo da via

\subsection{A NOVA POLÍTICA NACIONAL DE TRÂNSITO}

A partir de 1997, com a introdução do novo Código de Trânsito Brasileiro (CTB), começou-se a implantar no Brasil uma nova Política Nacional de Trânsito (PNT). Tal ação tem como propósito resgatar a harmonia, em termos de circulação 
nas vias urbanas, entre os transportes motorizados e não motorizados, proporcionando a esses últimos maior segurança e comodidade em suas operações.

O caráter de urgência para a adoção de tal medida evidenciou-se principalmente pelos números elevados dos registros de violência no trânsito, bem como pela perda da qualidade de vida observada no meio urbano.

Tais situações corroboram tanto para o aumento dos custos sociais e ambientais como também, para o incremento na desigualdade entre as classes sociais existentes no país, devido à dificuldade de acesso ao trabalho das pessoas menos favorecidas, em termos econômicos.

Segundo um estudo desenvolvido pelo Instituto de Pesquisa Econômica Aplicada (IPEA, 2003), o custo social decorrente de acidentes de trânsito em aglomerados urbanos atinge um valor anual correspondente a 5,3 bilhões de reais.

A nova Política Nacional de Trânsito (PNT) procura exatamente minimizar os conflitos sociais, econômicos e ambientais, através da implantação de novos modelos de desenvolvimento urbano e de transporte, considerando ainda o conceito do desenvolvimento sustentável, procurando integrar o trânsito ao uso do solo, ao desenvolvimento urbano e regional, bem como ao transporte em suas diferentes modalidades.

Dentre as diretrizes gerais contidas na nova Política Nacional de Trânsito (PNT) podem-se citar as seguintes:

- Aumentar a segurança de trânsito

- Promover a educação para o trânsito

- Garantir a mobilidade e acessibilidade com segurança e qualidade ambiental a toda população

- Promover o exercício da cidadania, a participação e a comunicação com a sociedade - Fortalecer o Sistema Nacional de Trânsito 


\subsection{CONSIDERAÇÕES FINAIS}

A bicicleta tem um papel importante na produção industrial e como veículo de transporte e lazer na vida brasileira. Em estudo realizado pelo GEIPOT (2001) há informações de que as bicicletas utilizadas como meio de transporte (populares, tipo barra-forte) são as mais vendidas no país com cerca de $45 \%$ das vendas, vindo a seguir as infanto-juvenis com $30 \%$ e as esportivas, acima de uma marcha, com $25 \%$, segundo a Associação Brasileira dos Fabricantes de motocicletas, ciclomotores, motonetas e bicicletas (Abraciclo). No mesmo estudo, há informações que a Associação Brasileira dos Fabricantes, Distribuidores e Importadores de Bicicletas, Peças e Acessórios (Abradibi) afirma que as bicicletas de transportes detêm 55\% das vendas.

Na distribuição por região geográfica, segundo a Abraciclo, a região sudeste ocupa o primeiro lugar, com $40 \%$, seguindo-se a nordeste com $28 \%$, a sul com $22 \%$, a centro-oeste com $6 \%$ e, finalmente, a norte com $4 \%$ das vendas de bicicletas.

Segundo o GEIPOT (2001), ocorre um crescimento significativo do uso da bicicleta no país. Da frota estimada em 45 milhões de veículos, quase $2 / 3$ é utilizada como transporte, destacando-se o fato de que a classe operária hoje também utiliza para transporte, as mountain-bike, tipo esportivo desse veículo.

Estima-se que há no Brasil em torno de $350 \mathrm{Km}$ de ciclovias e ciclofaixas implantadas. Não obstante, esse é um número inexpressivo, considerando que uma cidade com apenas 20000 habitantes possui sistema viário pavimentado com essa extensão. Ou seja, o conjunto de infra-estrutura cicloviária de todas as cidades brasileiras poderia estar contido em uma cidade de pequeno porte.

Pelo panorama exposto, até o presente momento, torna-se evidente a necessidade dos municípios brasileiros planejarem melhor os seus espaços urbanos, considerando também as viagens realizadas pelos transportes não motorizados, a fim 
de que tais usuários possam transitar de forma segura e confortável nas vias, sem causar conflitos entre si mesmos e também com os transportes motorizados, evitando com isso a redução de capacidade das vias.

A falta de uma infra-estrutura adequada para ciclistas, na cidade de Boa Vista, causa um problema aos deslocamentos dos pedestres. Considerando-se a tendência crescente do número de bicicletas no país, a falta de vias específicas para ciclistas no referido município e as diretrizes da nova política nacional de trânsito, torna-se evidente a necessidade de um estudo, no sentido de avaliar o quanto os pedestres são prejudicados em suas caminhadas.

Conforme descrito no capítulo 2, alguns métodos, como o do HCM (2000) e os demais que consideram o critério da capacidade, procuram medir o nível de serviço para calçadas, considerando apenas o fluxo de pedestres que passa em um intervalo de tempo de 1 minuto, por metro de largura efetiva de calçada. Outros métodos como, por exemplo, o de Ferreira e Sanches (2001), Sarkar (1993) e Khisty (1994), procuram medir o nível de serviço para calçadas considerando a segurança, a manutenção, a seguridade e a atratividade.

Percebe-se que há duas correntes distintas, em termos de métodos, para medir o nível de serviço das calçadas. Uma delas utiliza como critério a capacidade da calçada e a outra, adota como critérios, os fatores relacionados à segurança, conforto e comodidade dos pedestres.

Entretanto, nenhuma das correntes, menciona a influência dos ciclistas nos deslocamentos dos pedestres, portanto, avaliar o nível de serviço das calçadas, na cidade de Boa Vista, por qualquer um dos métodos citados neste trabalho, pode não refletir a qualidade de caminhada dos pedestres.

Duncan, Khattak e Hughes (2002) comentam que para um melhor entendimento sobre os fatores que contribuem para a situação de risco dos pedestres, devem ser estudadas, em pesquisas futuras, as interações entre os volumes de 
pedestres, uso do solo, volume de veículos, velocidade dos veículos, geração de viagens para pedestres, etc.

Por este motivo, torna-se necessário a elaboração de um novo método para avaliar o nível de serviço das calçadas, e que reflita a realidade de Boa Vista, ou seja, deverão ser considerados todos os parâmetros que causam impedância aos deslocamentos dos pedestres na via urbana. Além disso, o método a ser elaborado deverá considerar, como critério, o nível de satisfação dos pedestres quando estes têm que dividir o espaço destinado aos seus deslocamentos, com os ciclistas.

A definição de um método, compatível com a realidade local, é de extrema importância para que os órgãos municipais possam utilizá-lo, no futuro, como subsídio a um futuro plano diretor da cidade, com o intuito de que sejam previstas e dimensionadas infra-estruturas adequadas para a circulação de pedestres. 


\section{Capítulo 4}

\section{MÉTODO UTILIZADO NA PESQUISA}

\subsection{INTRODUÇÃO}

Neste capítulo é apresentado o método utilizado na pesquisa a fim de alcançar os objetivos propostos. Primeiramente, é feito um comentário sobre a hipótese adotada na pesquisa. Em seguida, é descrita, de forma detalhada, a aplicação do método, que diz respeito à seleção das variáveis e a coleta de dados realizada em campo.

É mostrada a forma como os dados devem ser processados nesta pesquisa e, como são utilizadas as técnicas de árvore de decisão e classificação e da regressão robusta $\mathrm{mm}$, para que seja obtido o modelo de dimensionamento de calçadas. Por fim, é descrito o critério para verificar a consistência do modelo proposto nesta pesquisa.

\subsection{A HIPÓTESE CONSIDERADA NA PESQUISA}

Os principais trabalhos para definir o nível de serviço de calçadas podem ser enquadrados em duas correntes distintas. A primeira utiliza o critério da capacidade. Considera o fluxo de pedestres e desconsidera os demais fluxos existentes em uma via, bem como o ambiente de caminhada dos pedestres e os possíveis conflitos entre 
os transportes motorizados e não motorizados, nesta corrente destacam-se os trabalhos de Fruin (1971) e do HCM (2000).

A segunda corrente utiliza o critério da condição do ambiente de caminhada dos pedestres, e aborda aspectos físicos e geométricos das calçadas e das vias, porém, não considera nenhum tipo de fluxo (pedestres, ciclistas, veículos, etc.). Nesta corrente destacam-se os trabalhos de Sarkar (1993), Khisty (1994), Dixon (1996) e Ferreira e Sanches (2001).

Entretanto, ambas as correntes não avaliam o nível de serviço das calçadas considerando a interação dos pedestres com os demais usuários de uma via. Nesta pesquisa, pretende-se avaliar esta condição a partir da seguinte hipótese:

"À medida que o fluxo de veículos motorizados de uma via aumenta, há a tendência de parte dos ciclistas que circulam pelos bordos desta, incomodados pelos veículos, deslocarem-se para as calçadas da via, prejudicando o deslocamento dos pedestres".

Por este motivo, nesta pesquisa são consideradas, além do fluxo de pedestres, as seguintes variáveis: fluxo de veículos motorizados; número de faixas de rolamento; largura da faixa de rolamento; e largura efetiva da calçada. Concomitantemente a esses levantamentos foi realizada uma pesquisa de opinião com os pedestres.

Percebe-se que as variáveis citadas pertencem às duas correntes que estudam nível de serviço para calçadas. Porém, nesta pesquisa, com o intuito de verificar a percepção dos pedestres sob condições reais de caminhada, foi acrescentada a esse conjunto, a seguinte variável: fluxo de ciclistas na via. Tal variável não é mencionada em nenhuma das correntes citadas.

Com a inclusão do fluxo de ciclistas neste trabalho, e a partir da hipótese proposta nesta pesquisa, elabora-se um modelo para o dimensionamento de calçadas considerando o nível de satisfação dos pedestres. 
A verificação da aceitabilidade da hipótese assumida é feita, com base no princípio da verossimilhança, a partir da comparação do modelo proposto com outros estudos que definem nível de serviço para calçadas, encontrados na bibliografia.

São destacados, em ralação a outros estudos, a importância e a finalidade dos dados coletados nesta pesquisa, sendo descrita a forma de sua obtenção, confrontando-a com a forma de obtenção em outros estudos. A partir destas comparações, pretende-se verificar a consistência do modelo proposto.

Verifica-se a consistência prática do modelo proposto, comparando os resultados deste com os resultados de outros estudos encontrados na bibliografia.

Não se pretende aqui, após a verificação da hipótese proposta, afirmar que o modelo representa o nível de serviço de calçadas em geral nem afirmar que este é mais eficiente que os modelos já existentes. Mesmo porque a verificação é válida apenas para situações em que a calçada está livre de ciclistas.

O que se pretende é mostrar que, quando a variável fluxo de ciclistas é desconsiderada no modelo proposto, este pode ser utilizado em outros locais, pois ele é corroborado pelos modelos existentes, amplamente verificados. Mesmo para situações em que há presença de ciclistas na calçada, o modelo tenderia a apresentar credibilidade maior, uma vez que uma parte dele estaria corroborada por modelos utilizados em vários países do mundo. Seja como for, não se pode afirmar nada a respeito do desempenho do modelo para a situação em que a calçada é ocupada também por ciclistas.

A intenção do autor da tese não é, tampouco, de demonstrar que o modelo explica situações gerais, com e sem ciclistas, porque no tempo limitado para a conclusão desta tese não seria possível efetuar verificações abrangentes. Mesmo com resultado favorável ao modelo proposto, o resultado poderia ser contestado por conter apenas alguns casos que, por acaso, poderia estar favorecendo o modelo. Por ora pode-se afirmar que o modelo possui confiabilidade para ser aplicado à cidade de Boa Vista. 
A aceitação do modelo proposto para aplicação em outras localidades dependerá de sua verificação em várias calçadas de várias cidades. Quando houver um conjunto grande de casos favoráveis e desfavoráveis, poderá ser emitido um parecer quanto ao desempenho geral do modelo.

\subsection{COLETA DE DADOS}

Neste tópico é feita uma descrição das atividades que serão efetuadas nesta fase da pesquisa. São descritos os processos de escolha e caracterização das vias estudadas, bem como a abordagem feita sobre os aspectos geométricos e operacionais destas, incluindo a forma de como estes são obtidos.

\subsubsection{SELEÇÃO E CARACTERIZAÇÃO DAS VIAS}

Foram escolhidas algumas vias da cidade de Boa Vista que apresentam um fluxo considerável de ciclistas e pedestres. Tal escolha foi realizada a partir de observações preliminares, in loco, que definiram também os respectivos horários de pico das vias em questão, para o fluxo de veículos motorizados.

Após esta identificação, procurou-se caracterizar as vias de acordo com o seu aspecto funcional. Portanto, antes das contagens de campo foi apontado se a via em questão é do tipo arterial, coletora, local ou residencial.

Esta caracterização se faz necessária, pois, a velocidade regulamentada para os veículos motorizados nas vias locais e residenciais é menor do que a velocidade regulamentada para as vias arteriais e coletoras. Além disso, a freqüência de ônibus e caminhões nas duas últimas vias citadas é maior, e o volume de tráfego em geral é mais elevado. Tais fatos colaboram para que os ciclistas sintam-se menos seguros e 
mais incomodados com a presença dos veículos motorizados nestas vias, conforme comentam Davis (2001) e Stinson e Bhat (2003).

\subsubsection{CARACTERIZAÇÃO DOS ASPECTOS GEOMÉTRICOS DAS VIAS}

Após a seleção das vias, foram registrados "in loco" os aspectos geométricos das mesmas, dentre estes foram escolhidos alguns referentes à pista de rolamento e outros referentes às calçadas.

\subsubsection{ASPECTOS RELACIONADOS À PISTA DE ROLAMENTO}

Com relação à pista de rolamento foram anotadas as dimensões das seguintes variáveis: número de faixas de rolamento; largura das faixas de rolamento; largura de ciclofaixas (caso exista esse tipo de infra-estrutura) e a declividade (transversal e longitudinal) das vias.

A declividade longitudinal foi registrada apenas por uma questão formal, de caracterização geral da pista, pois sendo Boa Vista uma cidade plana, este fator não representa uma impedância ou desconforto aos deslocamentos dos pedestres ou ciclistas. Entretanto, pretendeu-se mostrar que com o aumento do tráfego motorizado, há uma tendência maior ou menor de os ciclistas se deslocarem para as calçadas, em função do maior ou menor número de faixas de rolamento da via, bem como da maior ou menor dimensão destas faixas. Portanto, a consideração destes fatores foi relevante para a verificação da hipótese proposta nesta pesquisa.

Landis et al (2001) consideraram estas variáveis em seu estudo, porém, a não consideração do fluxo de ciclistas na via, e portanto, a interação que existe entre todos 
os usuários pode não refletir a qualidade dos deslocamentos dos pedestres sobre a calçada.

\subsubsection{ASPECTOS RELACIONADOS À CALÇADA}

Nesta pesquisa foram definidas 6 seções distintas de calçadas nas vias estudadas. Em cada uma das seções foi considerada a presença de equipamentos urbanos (postes de iluminação, lixeiras, placas de sinalização, etc) que pudessem promover uma impedância aos deslocamentos dos pedestres. A partir das considerações feitas, foram definidas 6 larguras efetivas de calçada com as seguintes dimensões: 0,90 m; 1,50 m; 2,00 m; 2,20 m; 2,50; e 4,70 m.

Dixon (1995) definiu em seu estudo apenas uma largura efetiva que foi 1,53 m. Já Ferreira e Sanches (2001) definiram 3 valores para este fator: 0,70 m; 1,20 m e 2,00 m. Entretanto, ambos os trabalhos não consideraram o fluxo de pedestres que caminhavam sobre esses espaços e sim, a existência ou não de tais dimensões, livres para a circulação de pedestres, em uma calçada.

Sarkar (1993) considerou em seu estudo apenas a presença ou não de obstáculos na calçada, porém, semelhantemente a Dixon (1995) e Ferreira e Sanches (2001), não considerou o fluxo de pedestres sobre a calçada.

Desta forma, com 6 larguras adotadas nesta pesquisa, pode-se ter uma noção melhor sobre a percepção do pedestre, quando este se desloca em calçadas com larguras efetivas diferentes, sob as condições operacionais da via. Além disso, poderá ser verificada nesta pesquisa, a possibilidade de calçadas mais largas serem atrativas aos ciclistas, deslocando-os dos bordos da via para cima destas, prejudicando os deslocamentos dos pedestres. 


\subsubsection{CARACTERIZAÇÃO DOS ASPECTOS OPERACIONAIS DAS VIAS}

Com relação aos aspectos operacionais, deverão ser coletados nesta pesquisa os fluxos de veículos motorizados; ciclistas; e pedestres.

\subsubsection{CARACTERIZAÇÃO DO FLUXO DE VEÍCULOS MOTORIZADOS}

Será realizada uma contagem classificatória do fluxo de veículos motorizados, nas vias estudadas. Esta atividade será realizada em um período de 2 horas, e em intervalos de 5minutos. Serão feitos registros de contagem para dois períodos distintos da via: pico e entre picos.

Esta contagem será realizada concomitantemente com a contagem dos fluxos de pedestres e ciclistas, a fim de verificar a influência do tráfego motorizado no comportamento dos ciclistas quanto ao uso ou não das calçadas para transitar, causando uma impedância aos deslocamentos dos pedestres.

Nos trabalhos existentes para a determinação do nível de serviço para calçadas, apenas alguns consideram a presença de veículos motorizados na via, entretanto, nestes trabalhos não são definidos fluxos de veículos motorizados e sim, alguns aspectos da via que possam provocar conflitos entre veículos e pedestres (número de interseções, faixas segregadas para veículos nas interseções, etc.). Dentre esses trabalhos podem ser citados Sarkar (1993), Khisty (1994), Dixon (1995) e Ferreira e Sanches (2001).

Outro trabalho considerou o volume de tráfego médio, dos veículos motorizados de uma via, em intervalos de tempo de 15 minutos, porém, a contagem além de não considerar os períodos de pico e entre picos, não foi classificatória. Os 
autores não consideraram também o fluxo de ciclistas e pedestres (Landis et all, 2001).

Os trabalhos citados acima não definem nível de serviço para calçadas, considerando os aspectos operacionais das vias, ou seja, não avaliam a percepção do pedestre quando este interage com os demais usuários da via.

Considerando esta interação, a variação do fluxo de veículos que ocorre na via, inclusive em períodos diferentes do dia, torna-se fundamental para a percepção da qualidade de deslocamento do pedestre, pois, conforme a hipótese proposta neste trabalho, o aumento do fluxo de veículos motorizados tenderá a deslocar um maior número de ciclistas para a calçada.

A contagem classificatória de veículos se faz necessária, pois a presença de ônibus e veículos mais pesados, que tendem a se deslocar mais pelos bordos da via, poderá levar um maior número de ciclistas para a calçada, causando conflitos com os pedestres.

Considerando-se que, as condições operacionais de uma via variam muito ao longo do dia e a influência do fluxo de veículos motorizados sobre os ciclistas, acredita-se que, contagens realizadas em intervalos de 15 minutos poderão ser prejudiciais para a determinação da insatisfação média dos pedestres, pois alguns pedestres podem estar caminhando na calçada sob condições mais críticas do que outros. Por outro lado, num intervalo menor do que 5 minutos podem ocorrer poucos eventos, de maneira que o número de eventos seja insuficiente para assegurar a representatividade do fenômeno avaliado.

Com a utilização de intervalos menores de contagens (5 minutos), acredita-se que a satisfação dos pedestres sobre a calçada será melhor avaliada. 


\subsubsection{CARACTERIZAÇÃO DO FLUXO DE PEDESTRES E CICLISTAS}

Nesta pesquisa são contados dois fluxos de pedestres: o que utiliza a calçada da via e passa pela largura efetiva previamente estabelecida, conforme descrito no sub-ítem 4.3.2.2, e o que utiliza os bordos da via.

Os fluxos de ciclistas foram contados da mesma forma, ou seja, foi anotado o fluxo de ciclistas que utiliza os bordos da via, e o fluxo de ciclistas que utiliza a calçada da via e passa pela largura efetiva previamente estabelecida.

As contagens de campo, referentes aos fluxos de pedestres e ciclistas, foram realizadas de forma simultânea, de maneira bi-direcional, inicialmente, num período de 2 (duas) horas/dia, em sub-períodos de 5 (cinco) minutos, durante 4 (quatro) meses, para que se tivesse uma sensibilidade maior sobre as variações que ocorrem tanto no comportamento como no fluxo de pedestres e ciclistas ao longo do turno de avaliação que compreendeu os períodos de pico e entre picos das vias estudadas. A definição do período de 4 (quatro) meses de contagens deve-se à indisponibilidade de um grande número de pesquisadores de campo.

Conforme comentado anteriormente, apenas alguns métodos consideram o fluxo de pedestres para definir nível de serviço de calçadas. Dentre estes destacam-se Fruin (1971) e o HCM (2000). Entretanto, nenhum dos dois consideram as condições operacionais da via, e muito menos a opinião dos pedestres sobre seus deslocamentos.

Desta maneira, por mais que a calçada apresente um nível de serviço $A$, em termos de fluxo de pedestres, a presença de ciclistas sobre esta pode causar uma perda na qualidade dos deslocamentos dos pedestres. Portanto, a consideração do fluxo de ciclistas se faz relevante na definição de nível de serviço para calçadas, 
principalmente nos países onde isso não é considerado infração. A carência desta variável pode ser notada também no método de Mori e Tsukaguchi (1987).

\subsubsection{CONSIDERAÇÕES SOBRE A PESQUISA DE OPINIÃO COM PEDESTRES}

No mesmo período da contagem de fluxos, foi realizada uma pesquisa de opinião junto aos pedestres que transitavam nas seções de calçadas demarcadas para a pesquisa, no sentido de obter desses, informações sobre a qualidade dos seus deslocamentos nas calçadas. Assim, foi perguntado aos pedestres se naquele momento se sentiam satisfeitos ao se deslocarem na seção de calçada em que se encontravam. As respostas foram do tipo SIM/NÃO.

Com a utilização das questões dicotômicas pretende-se, nos sub-períodos de contagem, obter o maior número possível de informações, pois, sendo as entrevistas realizadas durante o período comercial, envolvendo inclusive os horários de pico, a aplicação de um questionário, por menor que este seja, deverá dificultar a obtenção das respostas devido à indisponibilidade de tempo por parte dos entrevistados. Dentre algumas vantagens das questões dicotômicas podem-se citar as seguintes:

- Rapidez e facilidade na aplicação, no processo de dados e análise;

- Obtenção mais rápida das respostas;

- Menor risco de parcialidade do entrevistador;

- Apresentam pouca possibilidade de erros;

- São altamente objetivas.

Dentre as desvantagens da utilização das variáveis dicotômicas podem-se citar as seguintes:

- O tamanho da amostra deve ser grande. 
- Variáveis explanatórias, não trazem gradação, o que acarreta geralmente erros padrões maiores.

Como forma de enriquecer as informações obtidas através da aplicação das variáveis dicotômicas, para cada intervalo de tempo de contagem será computada a média das respostas dos pedestres.

Com a pesquisa de opinião, procurou-se definir um índice de satisfação médio para os pedestres. Porém, como há uma variação muito grande nas condições operacionais de uma via, durante o dia, torna-se difícil a definição de um intervalo de tempo para contagem, pois, caso este seja muito espaçado, em torno de 10 minutos, haverá a possibilidade de alguns pedestres estarem trafegando na via sob condições mais críticas do que outros. Assim, a obtenção da satisfação média será dada por valores complementares a um.

Desta forma, com o intuito de procurar reduzir este efeito, optou-se por fazer as contagens de fluxo e as pesquisas de opinião em intervalos de tempo de 5 minutos, acreditando-se que nesse sub-período as variações nas condições da via seriam menores e proporcionariam respostas mais coerentes entre os pedestres. Convém destacar, que com intervalos muito pequenos, poucos pedestres passam por uma seção da calçada. Consequentemente, não seria obtida uma amostra representativa no intervalo.

Os trabalhos que consideram a opinião dos pedestres para definir nível de serviço para calçadas levam em conta apenas a percepção destes em relação ao ambiente de caminhada. Em tais trabalhos não se verifica a satisfação dos pedestres em relação ao seu próprio fluxo, e em relação aos demais fluxos existentes na via. Dentre estes trabalhos, pode-se citar Khisty (1994) e Ferreira e Sanches (2001).

Com a pesquisa de opinião nesta pesquisa, pretende-se definir parâmetros para projetos de calçadas que traduzam um melhor nível de satisfação aos pedestres, 
considerando os aspectos geométricos, físicos, operacionais e seções distintas de calçadas da via observada.

A obtenção desses parâmetros poderá auxiliar no planejamento de calçadas, levando em conta a perda de qualidade para deslocamentos dos pedestres provocada pelos ciclistas que invadem a calçada.

\subsection{PROCESSAMENTO DOS DADOS COLETADOS E OBTENÇÃO DE MODELOS}

Após o levantamento das variáveis em campo, estas devem ser organizadas em uma planilha formando assim um conjunto de dados. Os resultados da pesquisa de opinião feita com os pedestres sobre as calçadas serão adicionados também a este conjunto.

Conforme descrito no tópico 4.3.4, o resultado da pesquisa de opinião foi a média das respostas dos pedestres. Com o intuito de evidenciar o desconforto sentido pelos pedestres, quando estes estão expostos às condições operacionais de uma via, será adotada a porcentagem média da "insatisfação" dos pedestres como resultado desta pesquisa.

A fim de avaliar possíveis mudanças no comportamento dos ciclistas, em termos destes utilizarem ou não as calçadas, bem como verificar a variação da satisfação dos pedestres, ao conjunto de dados foi acrescentada uma coluna, com o intuito de considerar o efeito do pico nas observações, pois, foram realizadas contagens neste período e no período entre picos. Atribuiu-se o valor 0 (zero) para o período de pico e 1 (um) para o de entre picos.

As variáveis que compuseram o conjunto de dados foram as seguintes: horário, pico/entre-picos, fluxo de pedestres sobre a calçada, fluxo de pedestres fora da 
calçada, fluxo de ciclistas sobre a calçada, fluxo de ciclistas fora da calçada, fluxo de automóveis na via, fluxo de motos na via, fluxo de ônibus na via, fluxo de caminhões grandes na via, fluxo de caminhões pequenos na via, \% da insatisfação dos pedestres, largura efetiva da calçada, número de faixas de rolamento da via e a largura das faixas de rolamento.

Desta forma, as diferentes variáveis, escolhidas para esta pesquisa incluindo a pesquisa de opinião, foram colocadas em colunas de uma planilha. A primeira coluna conterá o horário de contagem. Assim, cada linha da mesma planilha corresponde a uma resposta de pedestre, contida em um intervalo de 5 minutos e, mostra o resultado da contagem de cada variável e a porcentagem do nível médio da insatisfação dos pedestres para aquele período de coleta, individualmente.

Assim, observando em cada linha da planilha da esquerda para direita, pode-se ter uma noção sobre a insatisfação dos pedestres com os aspectos quantitativos de cada variável considerada, em um determinado intervalo de 5 minutos. Com relação à opinião dos pedestres, considerou-se nessa pesquisa, os valores 0 (zero) para pedestre satisfeito e 1 (um) para pedestre insatisfeito. No apêndice A desta pesquisa é apresentado um exemplo da referida planilha.

Os níveis médios de insatisfação, obtidos através da pesquisa de opinião realizada junto aos pedestres, foram considerados valores da variável dependente. As demais variáveis foram consideradas independentes. A fim de obter os principais fatores que interferem na insatisfação dos pedestres, quando estes caminham sobre a calçada da via, procurar-se-á fazer uma análise de todas as variáveis dependentes e independentes.

Nota-se que o conjunto de dados contém um volume considerável de informações (variáveis independentes) e que estas deverão apontar uma tendência de resposta de pedestres (variável dependente), em termos de insatisfação, quando estes 
utilizam uma dada seção de calçada sob determinadas condições operacionais das vias.

Considerando os fatores envolvidos na pesquisa e o seu escopo, optou-se por utilizar a Árvore de Decisão e Classificação, pois esta técnica permitirá a visualização, de forma hierarquizada, dos fatores acima mencionados.

\subsection{1 ÁRVORE DE DECISÃO}

A árvore de decisão é um diagrama ou gráfico de fluxo que representa um sistema de classificação ou um modelo preditivo, sendo estruturada como uma seqüência de questões simples, onde as respostas para tais questões traçam o caminho da árvore. Assim, o processo se caracteriza por dividir um problema complexo em subproblemas mais simples, oferecendo a vantagem de o pesquisador poder acompanhar o procedimento de classificação através dos nós da árvore.

A Figura 4.2 mostra um exemplo esquemático de Árvore de Decisão, aplicado à escolha modal. A variável dependente possui três categorias / modos de transporte (a pé, automóvel, ônibus). No exemplo, as variáveis independentes são: distância, idade, renda, sexo e número de automóveis no domicílio. O nó raiz é representado pelo retângulo cinza enquanto que os nós filhos por retângulos azuis. Nas folhas aparecem as figuras do modo de viagem escolhido. 


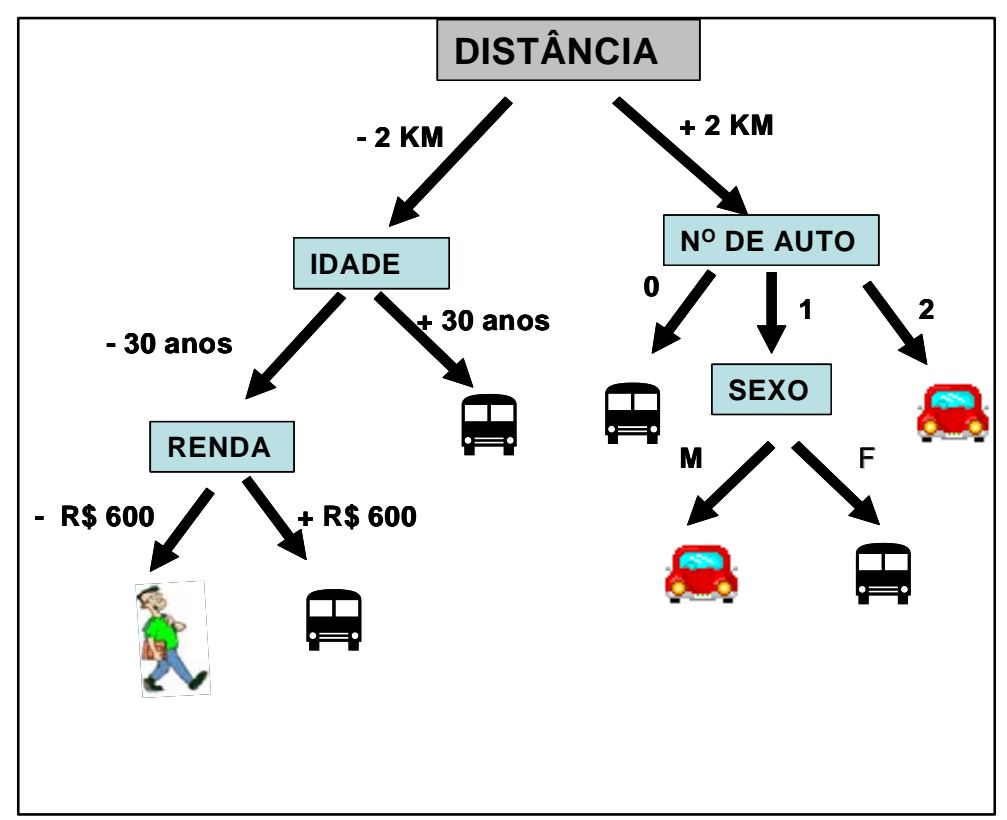

Figura 4.2: Diagrama sintético das principais características da Árvore de Classificação para um problema com três valores de variável resposta (a pé, automóvel e ônibus) e cinco preditoras (distância, idade, renda, sexo e número de automóveis no domicílio) Fonte: Pitombo e Kawamoto (2004).

As vantagens principais das árvores de decisão são: elas consideram as variáveis de maior relevância para segmentação dos dados e são compreensíveis para a maioria das pessoas. Ao escolher e apresentar as variáveis em ordem de importância, as árvores de decisão permitem aos usuários visualizar imediatamente quais fatores mais influenciam as suas classificações ou previsões. Portanto, oferecem uma estrutura clara e maior facilidade de compreensão dos resultados.

Nesta pesquisa será utilizado o Software S-Plus 6.1, em função dos seguintes aspectos: o programa apresenta uma interface mais acessível ao usuário; está disponível no Departamento de Transporte da EESC/USP; os relatórios emitidos pelo programa indicam a probabilidade de ocorrer uma determinada resposta (como no exemplo da figura 4.2), além de indicar a resposta predominante para cada nó da árvore.

A árvore contida no S-Plus 6.1 é uma variante do algoritmo do CART (do inglês, Classification And Regression Tree), que estabelece uma relação entre 
variáveis preditoras (ou explicativas) e variável resposta. O algoritmo é ajustado mediante sucessivas divisões binárias no conjunto de dados, de modo a tornar os subconjuntos resultantes cada vez mais homogêneos em relação à variável resposta. Essas divisões são representadas por estrutura de árvore binária, sendo que cada nó corresponde a uma divisão (BREIMAN et al., 1984).

Tanto as variáveis respostas quanto as preditoras podem assumir valores contínuos ou categóricos. Se a variável resposta for numérica, o modelo é conhecido como árvore de regressão e o modelo assume uma distribuição normal (gaussiana), e caso seja categórica, o modelo é denominado árvore de classificação e segue uma distribuição multinomial.

As componentes básicas de uma CART são os nós e as regras de divisão. Os nós estão associados aos subconjuntos resultantes da aplicação de uma regra de divisão a determinado conjunto de dados. As regras de divisão podem ser do tipo:

$>$ Idade < 14.5, no caso variável explicativa numérica, ou;

$>\mathrm{X} \in\{\mathrm{A}, \mathrm{B}\}$, para variável explicativa categórica.

As respostas às regras de divisão podem ser positivas ou negativas, dividindose nos ramos da árvore.

A função contida no S-Plus 6.1 permite até 128 valores de variáveis respostas categóricas e 32 para variáveis preditoras, pois se há $K$ níveis de variáveis preditoras, então ocorrerão " $\mathbf{2}^{(\mathbf{k}-1)}-1$ " divisões, que serão examinadas, impondo alta demanda de processamento computacional.

Para o término das divisões, S-Plus utiliza dois critérios:

I. Se a homogeneidade é menor do que um dado índice; e,

II. O número de observações no nó é menor do que um valor mínimo absoluto. 
O S-Plus 6.1 trata a árvore como modelo de probabilidade, empregando o desvio como critério de divisão. Para as árvores de classificação, a heterogeneidade é medida pelo desvio global (D):

$$
D=-2 \sum_{t} \sum_{j \in t} n(j \mid t) \log p(j \mid t)
$$

Em que: $n(j \mid t)$ é o número de casos no nó t com a resposta categórica j;

$p(j \mid t)$ denota a proporção dos casos na categoria j do nó t.

Significa que na árvore do S-Plus 6.1 o desvio foi definido como recíproco da função verossimilhança elevada ao quadrado. Portanto, o desvio é utilizado como uma medida da heterogeneidade dos grupos resultantes.

Na Tabela 4.1 apresenta-se um resumo das principais características da CART contida no S-Plus 6.1.

Tabela 4.1: Características Gerais do S-Plus 6.1. Fonte: baseada em Mesa et. al. (2000)

\begin{tabular}{ll}
\hline Tipo de variáveis de entrada & Categóricas ou Contínuas \\
\hline Tipo de variáveis Explicativas & Categóricas ou Contínuas \\
\hline Tipo de Resposta & $\begin{array}{l}\text { Variável Categórica (árvores de classificação) } \\
\text { Variável Numérica (árvores de regressão) }\end{array}$ \\
\hline Capacidade para controlar grande número de casos Sim \\
\hline Capacidade para controlar falta de dados & Não \\
\hline Segmentação & Binária \\
\hline Regras de Divisão & Árvores de Classificação- desvio \\
& Árvores de Regressão - Mínimo Quadrado \\
\hline Fornecimento de Árvore ótima & Não \\
\hline Limitação Variáveis Resposta & Até 128 valores \\
\hline Limitação Variáveis Explicativas & Até 32 variáveis \\
\hline Apresentação dos Resultados & Gráfico / Relatório \\
\hline Natureza dos Resultados & Gráfico - Determinístico \\
& Relatório - Probabilístico \\
\hline
\end{tabular}




\subsubsection{DEFINIÇÃO DAS VARIÁVEIS DE MAIOR INFLUÊNCIA NA SATISFAÇÃO DOS PEDESTRES}

Com a utilização da árvore de decisão, pretende-se nesta pesquisa identificar as variáveis que apresentam maior influência na insatisfação do pedestre, prejudicando o seu deslocamento sobre a calçada de uma via urbana. Serão considerados vários aspectos além dos relacionados à calçada, tais como a geometria, a funcionalidade e operação da via analisada.

Portanto, com a utilização do programa S-Plus 6.1 foram geradas árvores de decisão com características diferentes, em termos de número de observações mínimas nos nós, números mínimos de nós e desvio. Será adotada nesta pesquisa, a árvore que apresentar os melhores resultados, considerando as características mencionadas acima e a coerência com o fenômeno avaliado.

O resultado da árvore de decisão indicará, de forma hierarquizada, as principais variáveis que deverão ser utilizadas para gerar um modelo de dimensionamento de calçadas, em vias urbanas, considerando o nível de insatisfação dos pedestres, quando estes interagem com todos os aspectos (geométrico, físico e operacional) de uma via. As condicionantes de projeto deverão ser obtidas pela definição de um modelo estatístico.

Conforme descrito anteriormente, procurou-se obter, em cada intervalo de tempo de 5 minutos, o comportamento médio dos pedestres. Ou seja, procurou-se estimar o nível médio de insatisfação, em termos de porcentagem, quando estes realizam seus deslocamentos sobre as calçadas, levando-se em conta as variáveis de caráter geométrico e operacional das vias em questão. Portanto, para se alcançar o modelo estatístico, será considerada como variável dependente o nível médio de insatisfação dos pedestres. 
O nível de insatisfação 0 (zero) significa que num dado intervalo de 5 minutos todos os pedestres estavam satisfeitos. Contrariamente, o nível de insatisfação 1 (um) indica que todos os pedestres abordados num intervalo de 5 minutos estavam insatisfeitos.

Percebe-se então, que uma amostra da variável dependente terá uma variação não simétrica, portanto, os erros residuais desta não possuirão uma distribuição normal em relação a sua média, e apresentarão valores maiores, concentrados próximos aos valores extremos da amostra. Sendo assim, não se pode utilizar para modelagem os fundamentos da estatística paramétrica. Logo, a ferramenta a ser utilizada para a obtenção do modelo de dimensionamento de calçadas será a regressão robusta $\mathrm{MM}$, contida no software S-Plus 6.1 , que utiliza os conceitos da estatística não-paramétrica.

De acordo com Cunha et al (2002), as técnicas de regressão robusta são um importante complemento às técnicas clássicas dos mínimos quadrados, pois, fornecem respostas similares a estas, quando existe relação linear entre variáveis com os erros normalmente distribuídos, porém, diferem significantemente dos ajustes dos mínimos quadrados quando os erros não satisfazem as condições de normalidade, ou quando a amostra contém outliers significantes.

\subsubsection{TÉCNICAS DE REGRESSÃO ROBUSTA}

O estudo da estatística gira em torno de dois conceitos básicos; a tendência central e a dispersão de uma amostra. O estimador da tendência central mais simples e mais conhecido é a média aritmética. No âmbito da Estatística Básica, estuda-se também a média geométrica, a média harmônica, a mediana, a moda e a média 
ponderada. Todos estes estimadores têm o mesmo objetivo: identificar em torno de onde se distribuem os dados.

Após determinar a tendência central, é importante saber o quão dispersos estão os dados em torno desse ponto. Para isso usa-se o conceito de desvio-padrão ou variância. Assim, conhecendo a média e o desvio-padrão, pode-se calcular a probabilidade de atingir um valor situado à determinada distância da média.

O principal objetivo da Estatística Robusta é atenuar o efeito de outliers, que são pontos observados, com comportamento distinto em relação aos demais pontos de uma amostra, devido ao seu maior afastamento da média, parecendo assim inconsistentes.

Entretanto, a simples rejeição dos outliers não é um procedimento correto, pois existem regras para tal e essas devem incluir a re-análise de uma amostra, sem as observações inconsistentes que, dependendo das circunstâncias, podem ser portadoras de informações relevantes dos indivíduos da amostra. Assim, deve-se ter o cuidado para que não sejam eliminados pontos importantes de uma amostra, que acarretaria a omissão de algum valor da variável influente em um determinado modelo.

Desta forma, a regressão robusta além de ser utilizada para detectar esses pontos e minimizar o efeito dessas possíveis inconsistências, proporcionando resultados estáveis aos modelos estatísticos, possui outros papéis como preservar a forma, a dispersão e a simetria dos dados reais.

As técnicas mais comuns de regressão robusta utilizam as seguintes estimativas: a estimativa M proposta por Huber (1973); a estimativa LTS (Least Trimmed Squares) proposta por Rousseeuw (1984); a estimativa S proposta por Rousseeuw e Yohai (1984) e por fim, a estimativa MM proposta por Yohai (1987).

Pode-se dizer que um ajuste robusto MM sofre uma influência mínima dos outliers no espaço das variáveis independentes, no espaço da resposta (variável dependente), ou em ambos. 
Nos resíduos dos mínimos quadrados (LS), os outliers não são revelados claramente, já na estatística robusta eles são perfeitamente identificados. A distribuição normal cabida aos resíduos robustos, ignorando os outliers, tem um desvio padrão substancialmente menor do que a distribuição normal pertencente aos resíduos dos mínimos quadrados (LS). Neste sentido, o método robusto fornece um ajuste melhor ao volume dos dados.

Um modelo robusto MM tem a seguinte forma:

$$
y_{i}=x_{i} \beta+\varepsilon_{i} \quad i=1, \ldots, n
$$

Onde $y_{i}$ é a resposta escalar associada para o i-ésima observação, $x_{i}$ é um vetor $\mathrm{p}$-dimensional de valores das variáveis preditoras independentes, $\beta$ representa os coeficientes das variáveis e $\varepsilon_{i}$ são os erros ou resíduos.

A regressão robusta MM é uma combinação das técnicas M e LTS.

O LTS é um estimador que serve para definir o ponto de corte dos outliers. Tal estimador utiliza como referência para o cálculo do ponto de corte, o valor da mediana da mínima soma dos quadrados dos resíduos de uma amostra. Com isso, os valores dos maus pontos só poderão ter uma variação em torno de $50 \%$ do valor estipulado pelo LTS para que o modelo seja robusto. O estimador M procura minimizar ainda mais a influência dos resíduos de uma amostra aplicando a estes uma função peso.

O Método dos Mínimos Quadrados pondera cada observação igualmente na estimativa dos parâmetros do modelo $\left(\begin{array}{lll}\beta & \text { e } & \varepsilon\end{array}\right)$. A técnica robusta MM pondera as observações desigualmente na estimativa dos parâmetros do modelo $\left(\begin{array}{lll}\beta & e & \varepsilon\end{array}\right)$, colocando menos peso às observações que produzem maiores resíduos (outliers).

Essas técnicas de regressão são muito utilizadas para resolver, principalmente, os seguintes problemas:

- problemas com outliers na variável resposta (direção y); 
- problemas com outliers na direção do espaço x, que é o caso particular desta pesquisa e;

- problemas com outliers em ambas as direções, na direção y e no espaço x.

As técnicas da estatística não paramétrica são particularmente adaptáveis aos dados das ciências do comportamento. A aplicação dessas técnicas não exige suposições quanto à distribuição da população da qual se tenha retirado amostras para análises. Podem ser aplicadas a dados que se disponham simplesmente em ordem, ou mesmo para estudo de variáveis nominais. Diferentemente do que acontece na estatística paramétrica onde as variáveis são, na maioria das vezes, intervalares, os testes não-paramétricos são interessantes para análise de dados qualitativos.

\subsubsection{OBTENÇÃO DO MODELO PARA DIMENSIONAMENTO DE CALÇADAS}

A fim de gerar o modelo de dimensionamento de calçada, proposto nesta pesquisa, foi utilizada a Regressão Robusta MM contida no programa S-Plus 6.1. Com esta técnica deverão ser feitos vários tipos de combinações entre as variáveis obtidas, a partir do resultado da árvore de decisão. Com esse procedimento vários modelos foram gerados. Entretanto, deve-se fazer a verificação da representatividade destes em relação ao fenômeno estudado e, avaliar também se os coeficientes dos modelos são significativos.

Tal cuidado se faz necessário, pois com a utilização do programa S-Plus 6.1, na geração do modelo, o próprio usuário tenta sucessivamente as diferentes combinações das variáveis do modelo, para então escolher dos expoentes o conjunto que otimiza os resultado. Ademais, nem todos os conjuntos de expoentes traduzem coerentemente o comportamento dos pedestres, ou seja, são as mudanças que 
ocorrem na satisfação dos pedestres em deslocamento sobre as calçadas. Assim, o modelo mais coerente e representativo foi escolhido para dimensionamento de calçadas.

\subsection{VERIFICAÇÃO DO MODELO}

Pretende-se avaliar a consistência do modelo obtido nesta pesquisa, comparando os valores obtidos por este, com os resultados de outros estudos encontrados na bibliografia como, por exemplo, os estudos de Fruin (1971), CBTU (1979), EBTU (1984), e do HCM (2000). Tais estudos são relevantes no meio técnico e o último, principalmente, é muito utilizado no projeto de calçadas.

Deverá ser comparada a coerência, em termos de níveis de insatisfação dos pedestres, obtidos pelo modelo proposto, com a variação dos níveis de serviço propostos pelos referidos estudos. Caso esta comparação seja satisfatória, far-se-á uma equivalência entre os valores de insatisfação dos pedestres, obtidos pelo modelo proposto nesta pesquisa, e os níveis de serviço pregados pelo HCM (2000), respeitando-se as fronteiras estipuladas pelo método.

Para efeito de avaliação de projetos, o nível de serviço C é considerado aceitável pelo meio técnico. Os valores da insatisfação dos pedestres, obtidos pelo modelo proposto, serão dados em porcentagem. Assim, o modelo será considerado satisfatório e coerente com os demais estudos, quando os valores de insatisfação, referentes ao nível $\mathrm{C}$ em outros estudos, tiverem resultados abaixo de $50 \%$. Portanto, valores menores que $50 \%$ deverão representar os níveis de serviço $A, B$ e C e, valores maiores que $50 \%$ representarão níveis de serviço $\mathrm{D}, \mathrm{E}$ e $\mathrm{F}$, dependendo do nível de insatisfação. 
Uma vez verificada a consistência do modelo, ele será utilizado para avaliar o nível de serviço de calçadas em vias urbanas, agora considerando também a presença de ciclistas na calçada. Com isso, pretende-se estabelecer novas fronteiras, em termos do fluxo de pedestres por metro por minuto (pedestres $/ \mathrm{m} / \mathrm{min}$ ), semelhantemente ao HCM (2000), porém, considerando-se ainda, as variáveis destacadas nesta pesquisa, que mais afetam a satisfação dos pedestres quando estes se deslocam em uma via urbana, sujeitos a todas as condições operacionais da mesma. 


\section{Capítulo 5}

\section{CARACTERIZAÇÃO DAS VIAS ONDE FORAM REALIZADAS AS CONTAGENS}

\subsection{INTRODUÇÃO}

Neste capítulo são apresentadas as vias, e os respectivos locais, onde foram realizadas as coletas de dados. É feita uma caracterização geral, em termos da funcionalidade, geometria e dos aspectos físicos, pertencentes a cada um dos referidos pontos de coleta. Por fim, é apresentado um perfil geral, sobre os aspectos operacionais das vias estudadas, identificando a influência que o comportamento dos ciclistas, em termos de ocupação das calçadas, provoca na qualidade de deslocamento dos pedestres, refletida na porcentagem de usuários satisfeitos.

\subsection{SELEÇÃO DAS VIAS ESTUDADAS}

As vias selecionadas para as observações e contagens de campo foram as seguintes: Av. Mário Homem de Mello; Av. general Athayde Teive e Av. brigadeiro Eduardo Gomes. A escolha se deu em conformidade com o método proposto nessa tese, ou seja, tais vias apresentam fluxos bastante variável de pedestres, ciclistas e veículos ao longo do dia. Convém destacar que, além dos critérios apontados acima, as vias em questão aparecem nas estatísticas do Departamento Estadual de Trânsito 
de Roraima (DETRAN-RR) devido ao número de acidentes com graus de gravidade variando de leve a médio.

\subsection{CARACTERÍSTICAS FUNCIONAIS, GEOMÉTRICAS E FÍSICAS DAS VIAS ESTUDADAS}

As vias selecionadas para as contagens de campo, quanto à funcionalidade, são classificadas como arteriais, pois, além das características de tráfego, em termos de volume e velocidade, ligam diferentes regiões da cidade e ainda permitem a acessibilidade aos lotes lindeiros e às vias coletoras e locais. Convém destacar que das três vias selecionadas, apenas a Av. Brigadeiro Eduardo Gomes não faz a ligação centro-bairros. A seguir serão apresentadas algumas características, de forma individualizada, dos locais de contagem.

\subsubsection{Av. General Athayde Teive}

A avenida General Athayde Teive é uma via que possui duas faixas de rolamento, cada uma medindo $4,80 \mathrm{~m}$ de largura e uma rampa de $2 \%$. A extensão total da via é de, aproximadamente, $10 \mathrm{Km}$. A referida via possui um único sentido de tráfego (Bairro-Centro), onde pode ser observado o tráfego de caminhões e ônibus. Porém, nesta via existem poucos abrigos destinados aos usuários do transporte coletivo. Ao longo do meio fio da via não há estacionamentos regulamentados. 
Deve-se destacar que o sistema de drenagem e as condições de rolamento da referida via e suas calçadas encontram-se em razoável estado de conservação. Excetuando-se o período das chuvas mais intensas, quando há a formação de poças d'água nas laterais da via, tais fatores não causam prejuízos à operação dos transportes motorizados e não motorizados ao longo da mesma.

$\mathrm{Na}$ avenida Gen. Athayde Teive foram definidos dois pontos de contagem, ou seja, foram estabelecidas duas seções de calçadas com larguras efetivas de 2,20 m e 2,50 m. Ambas as seções podem ser identificadas nas Figuras 5.1 e 5.2 abaixo.

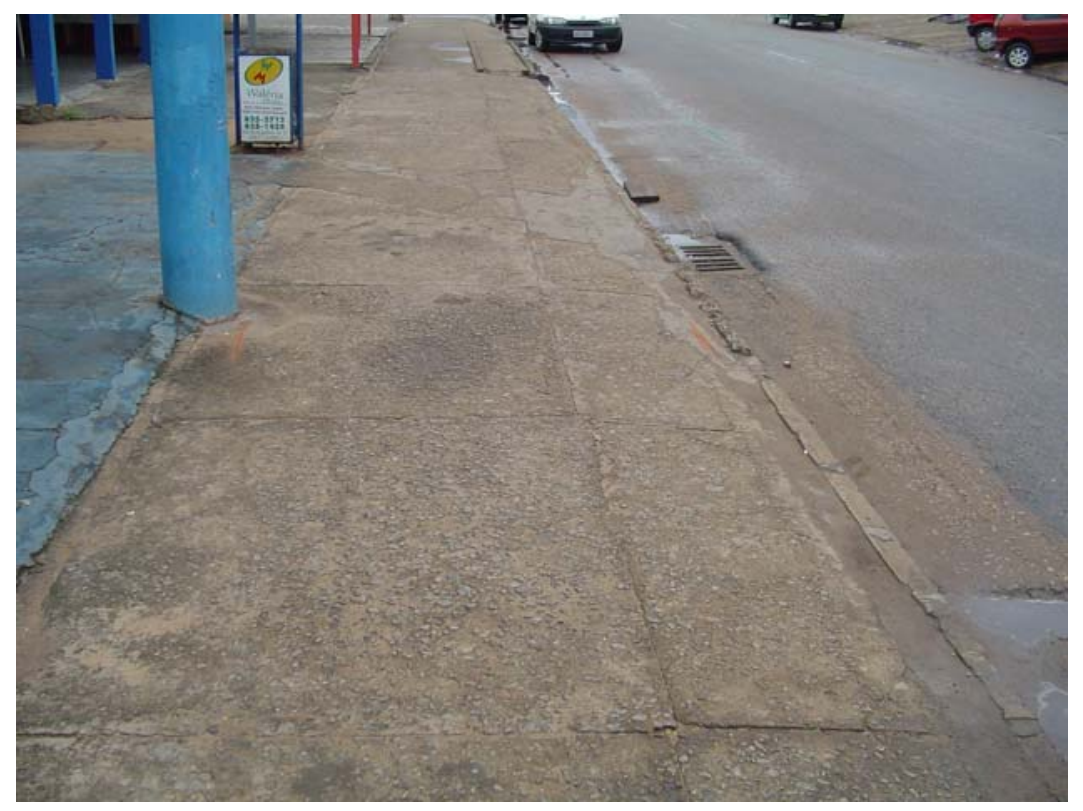

Figura 5.1- Calçada na avenida Gen. Athayde Teive com 2,20 m de largura efetiva. 


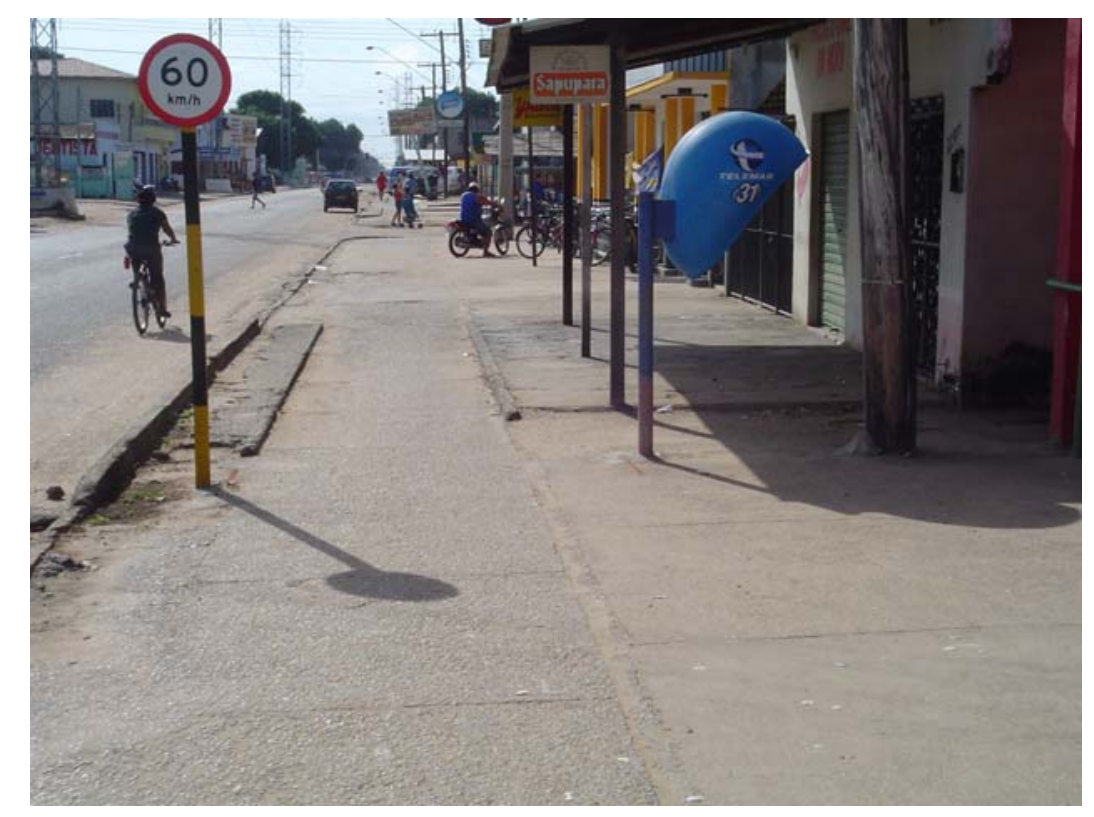

Figura 5.2- Calçada na avenida Gen. Athayde Teive com 2,50 m de largura efetiva.

\subsubsection{Av. Mário Homem de Mello}

A Av. Mário Homem de Mello é paralela à Gen. Athayde Teive, e juntamente com aquela forma um sistema binário, com o tráfego direcionado no sentido CentroBairro. É uma via que possui duas faixas de rolamento, com larguras variáveis em alguns trechos, e possui uma rampa de $2 \%$. A extensão total da via é de, aproximadamente, $8 \mathrm{Km}$. Ao longo do seu percurso trafegam caminhões e ônibus, porém poucos são os abrigos existentes destinados aos usuários do transporte coletivo nesta via. Constata-se também a inexistência de estacionamentos regulamentados, em qualquer posição, ao longo do seu meio-fio. As condições de drenagem, de rolamento e das calçadas dessa via encontram-se em razoável estado de conservação. Excetuando-se o período das chuvas mais intensas, quando há a formação de poças d'água nas laterais da via, tais fatores não causam prejuízos à operação dos transportes motorizados e não motorizados ao longo da mesma. 
Na Avenida Mário Homem de Mello foram definidos três pontos de contagem, pois existem três diferentes larguras efetivas de calçadas, e no local de cada uma dessas seções, há variação nas larguras das faixas de rolamento. As referidas dimensões para as observações dessa via podem ser vistas na tabela abaixo:

Tabela 5.1- Características dos pontos de contagem da av. Mário Homem de Mello

\begin{tabular}{|c|c|c|}
\hline Largura efetiva $(\mathrm{m})$ & Número de faixas de rolamento & Largura das faixas de rolamento $(\mathrm{m})$ \\
\hline 2,00 & 2 & 4,20 \\
\hline 1,50 & 2 & 4,55 \\
\hline 0,90 & 2 & 4,05 \\
\hline
\end{tabular}

Cada ponto de contagem da Av. Mário Homem de Mello pode ser identificado a partir das Figuras 5.3 a 5.5 abaixo.

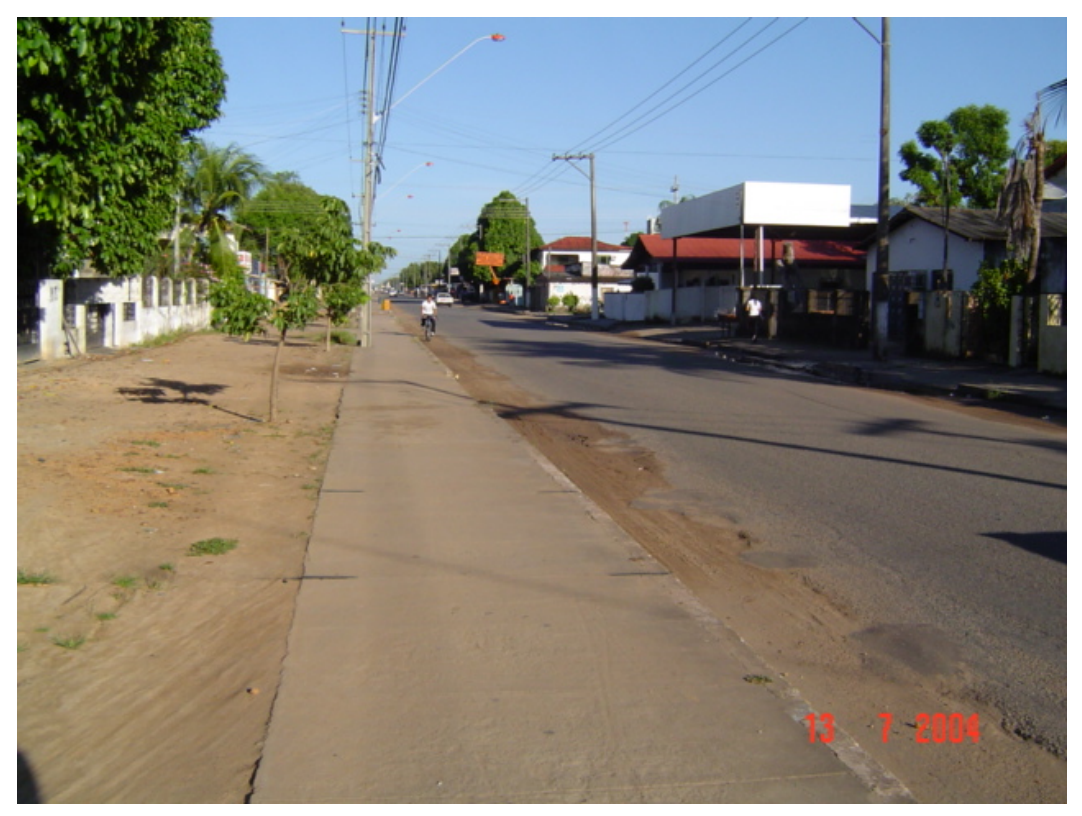

Figura 5.3 - Calçada na avenida Mário Homem de Mello com 2,00 m de largura efetiva. 


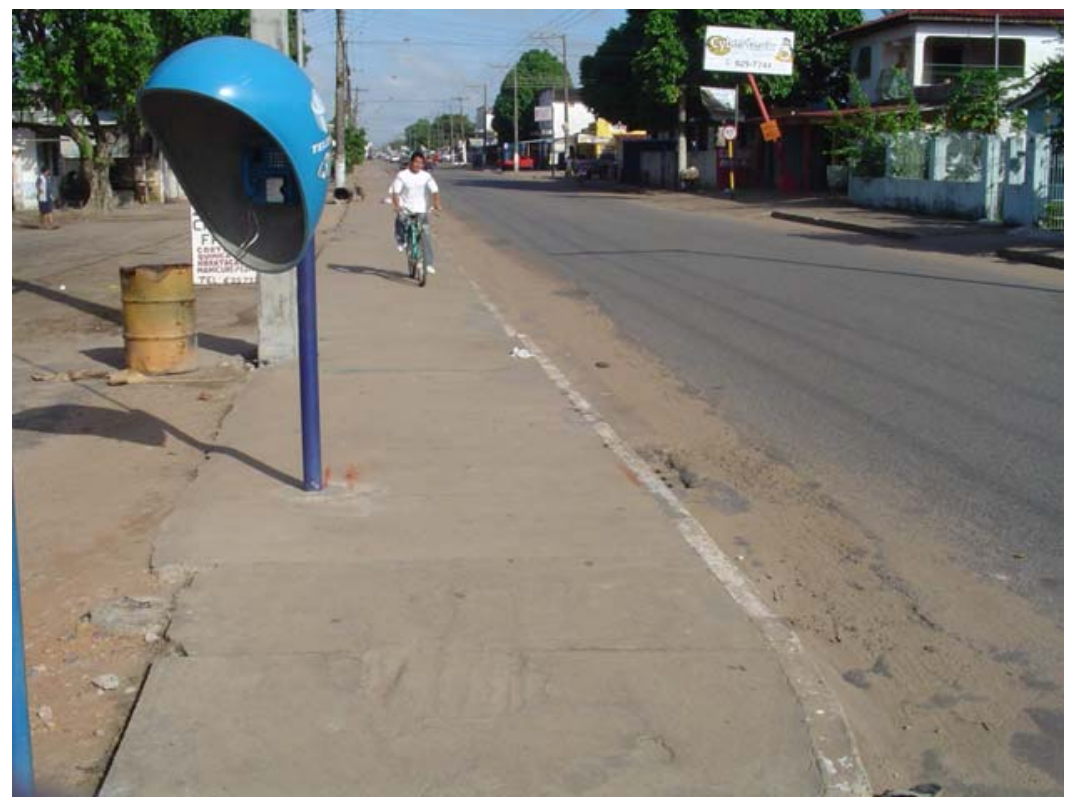

Figura 5.4 - Calçada na avenida Mário Homem de Mello com 1,55 m de largura efetiva.

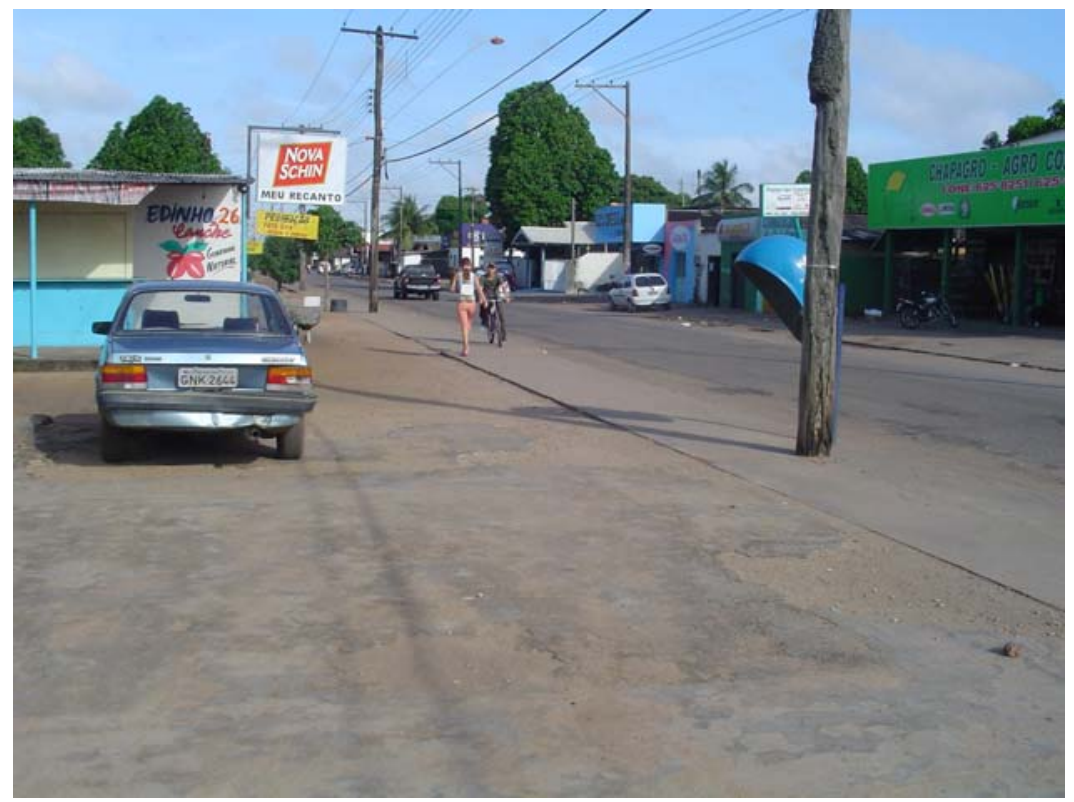

Figura 5.5 - Calçada na avenida Mário Homem de Mello com 0,90 m de largura efetiva. 


\subsubsection{Av. Brigadeiro Eduardo Gomes}

A Av. brigadeiro Eduardo Gomes possui três faixas de rolamento, cada uma medindo 4,50 m de largura. A extensão total dessa via é de, aproximadamente, $5 \mathrm{Km}$ e a mesma possui $2 \%$ de rampa. Ao longo do seu percurso trafegam caminhões e ônibus, porém poucos são os abrigos existentes destinados aos usuários do transporte coletivo nesta via. Semelhantemente às duas avenidas anteriormente descritas não existem estacionamentos regulamentados, em qualquer posição, ao longo do seu meio-fio. As condições de drenagem e rolamento dessa via encontram-se em razoável estado de conservação. Excetuando-se o período das chuvas mais intensas, quando há a formação de poças d'água nas laterais da via, tais fatores não causam prejuízos à operação dos transportes motorizados e não motorizados ao longo da mesma.

Essa via apresenta calçadas com superfícies mais regulares do que as outras duas vias citadas. A seguir apresenta-se uma foto do ponto de contagem da via em questão.

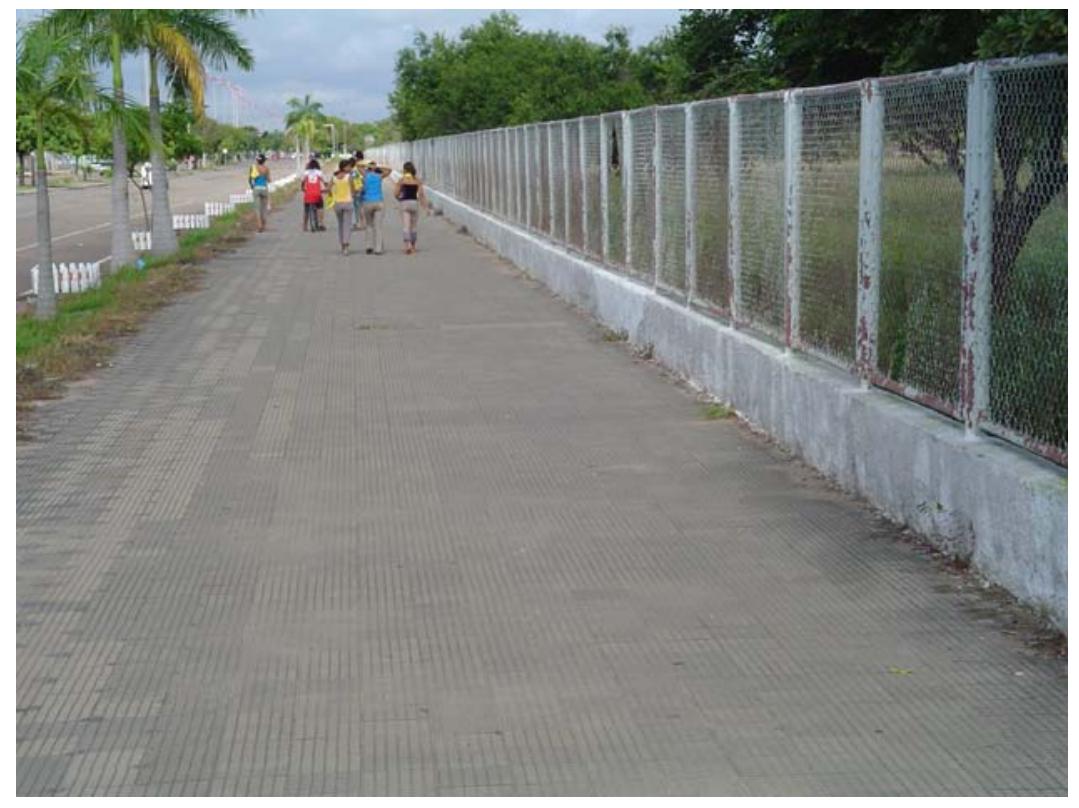

Figura 5.6 - Calçada na avenida brigadeiro Eduardo Gomes com 4,70 m de largura efetiva. 
A partir das Figuras apresentadas acima, pode-se detectar os aspectos físicos das seções de calçadas onde foi desenvolvida esta pesquisa, ou seja, são facilmente identificados os equipamentos urbanos como placas de sinalização, telefones públicos, lixeiras, postes de iluminação, etc, que proporcionam a redução da largura efetiva de uma calçada.

\subsection{CARACTERÍSTICAS OPERACIONAIS DAS VIAS ESTUDADAS}

As características operacionais das vias estudadas nesta pesquisa já foram apresentadas no item 3.4. Portanto, já são conhecidos os fluxos de veículos motorizados, ciclistas e pedestres, para ambos os períodos de contagens (pico / entrepicos), adotados nesta pesquisa. Sabe-se também que há uma tendência dos ciclistas utilizarem as calçadas da via para os seus deslocamentos, à medida que ocorre um aumento tanto do tráfego de veículos motorizados quanto de ciclistas nas vias.

Essa ocupação indevida das calçadas, por parte dos ciclistas, gera muitos conflitos desses usuários com os pedestres. Conforme foi demonstrado na tabela 3.2, os ciclistas apresentam uma ocupação significativa nas calçadas: 55 \% no período de pico e $50 \%$ no período entre-picos. Tal situação causa uma impedância aos deslocamentos dos pedestres.

As distinções de períodos serviram para definir melhor as variações dos comportamentos dos ciclistas e o nível de satisfação dos pedestres, além de definir melhor os parâmetros de maior influência na qualidade dos deslocamentos desses últimos sob condições diferenciadas de fluxos de veículos motorizados. 
Percebe-se que o comportamento dos ciclistas na via não é o mesmo quando são comparados os dois períodos de contagem. Ainda que haja no período entre-picos uma ocupação significativa de ciclistas sobre as calçadas, este chega a ter uma tendência decrescente no período entre-picos, diferentemente do que ocorre no período de pico. Nas Figuras abaixo são mostrados a distribuição do tráfego motorizado e as variações da tendência de ocupação das calçadas pelos ciclistas e pedestres, para cada uma das vias avaliadas nesta pesquisa.

\section{Av. Mário Homem de mello}

Distribuição dos veículos motorizados na

Av. Mário Homem de Mello (Pico)

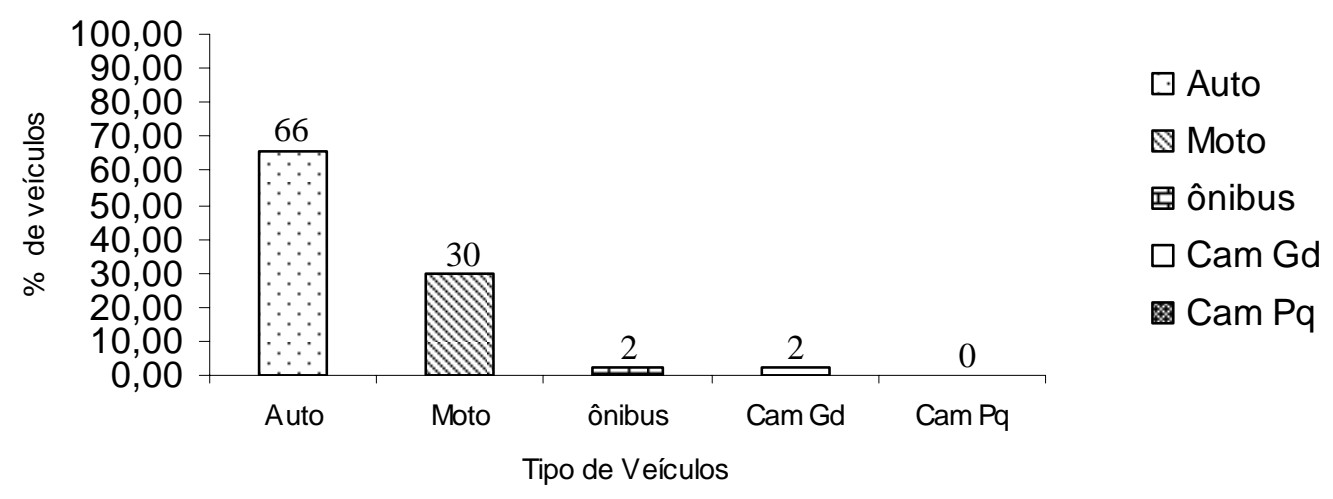

Figura 5.7 - Gráfico da distribuição dos veículos motorizados na Av. Mário Homem de Mello no período de pico. 


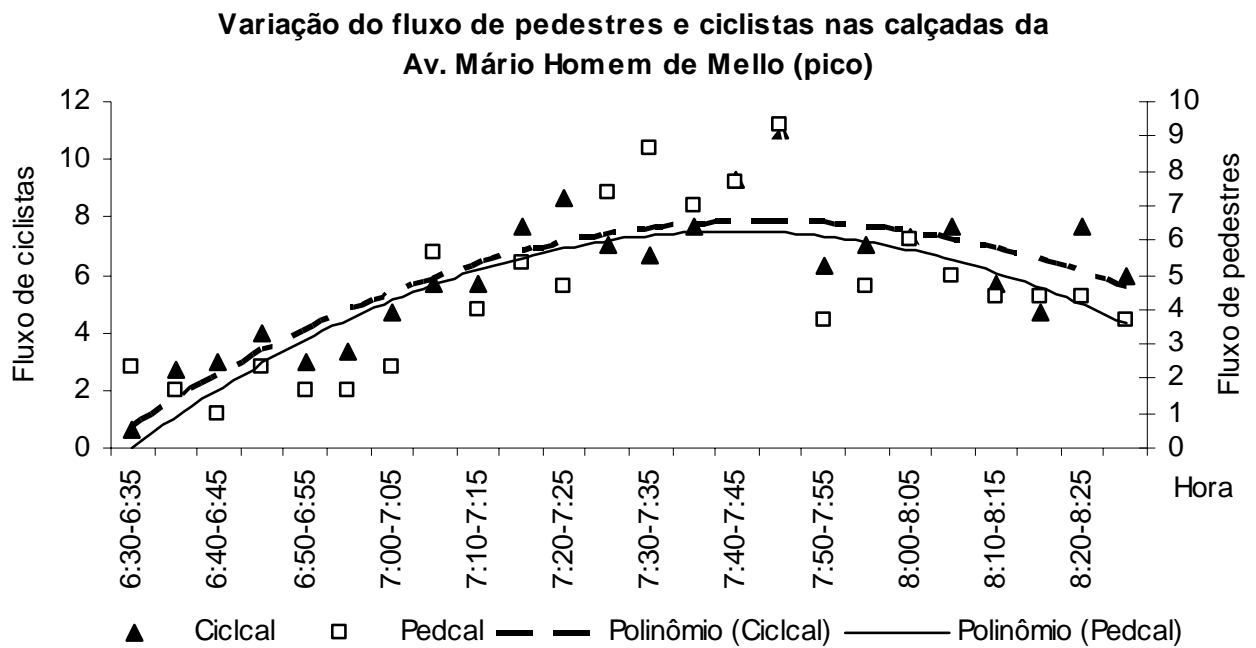

Figura 5.8 - Gráfico da comparação do fluxo de Pedestres e ciclistas sobre as calçadas na Av. Mário Homem de Mello no período de pico.

Distribuição dos veículos motorizados na

Av. Mário Homem de Mello (Entre-picos)

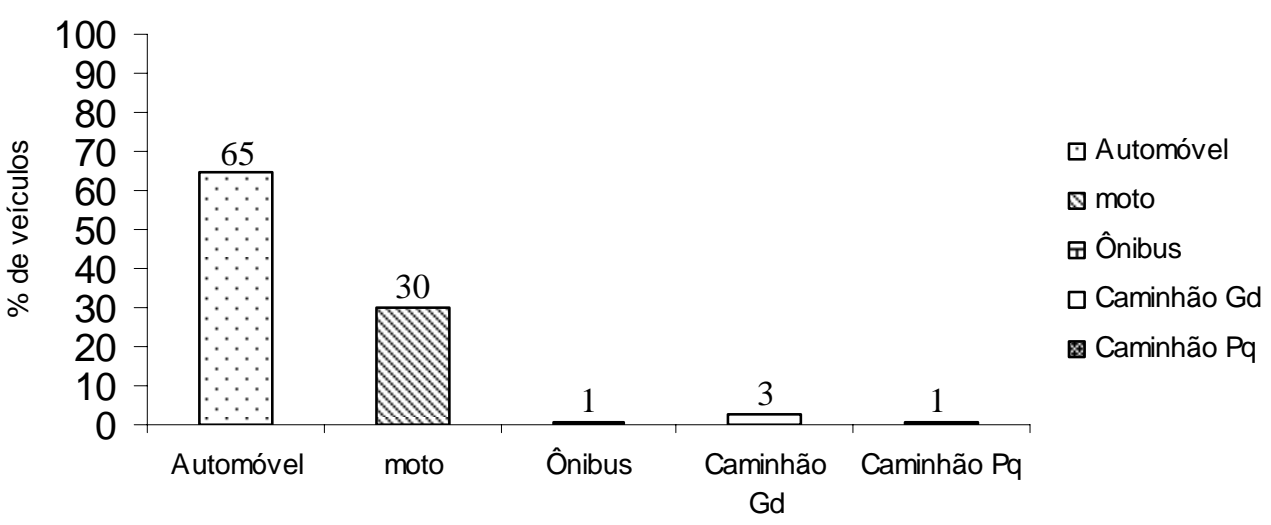

Tipo de veículos

Figura 5.9 - Gráfico da distribuição dos veículos motorizados na Av. Mário Homem de Mello no período entre-picos. 


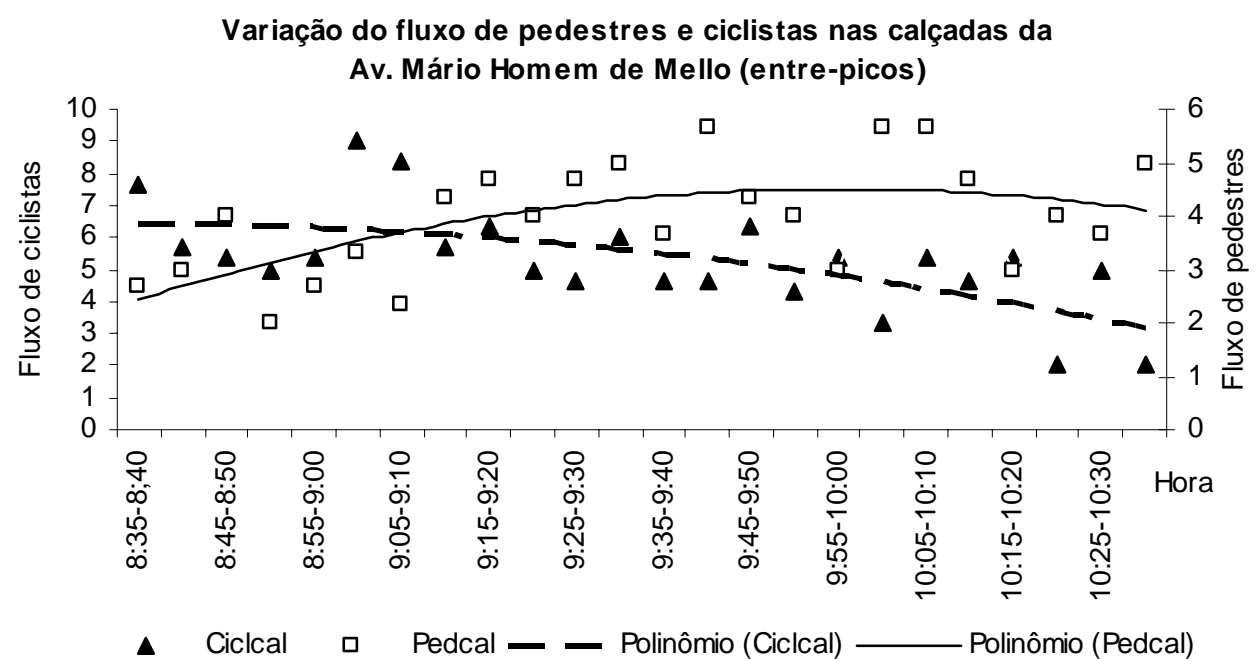

Figura 5.10 - Gráfico da comparação do fluxo de Pedestres e ciclistas sobre as calçadas na Av. Mário Homem de Mello no período entre-picos.

\section{Av. General Athayde Teive}

\section{Distribuição dos veículos motorizados na \\ Av. General Athayde Teive (Pico)}

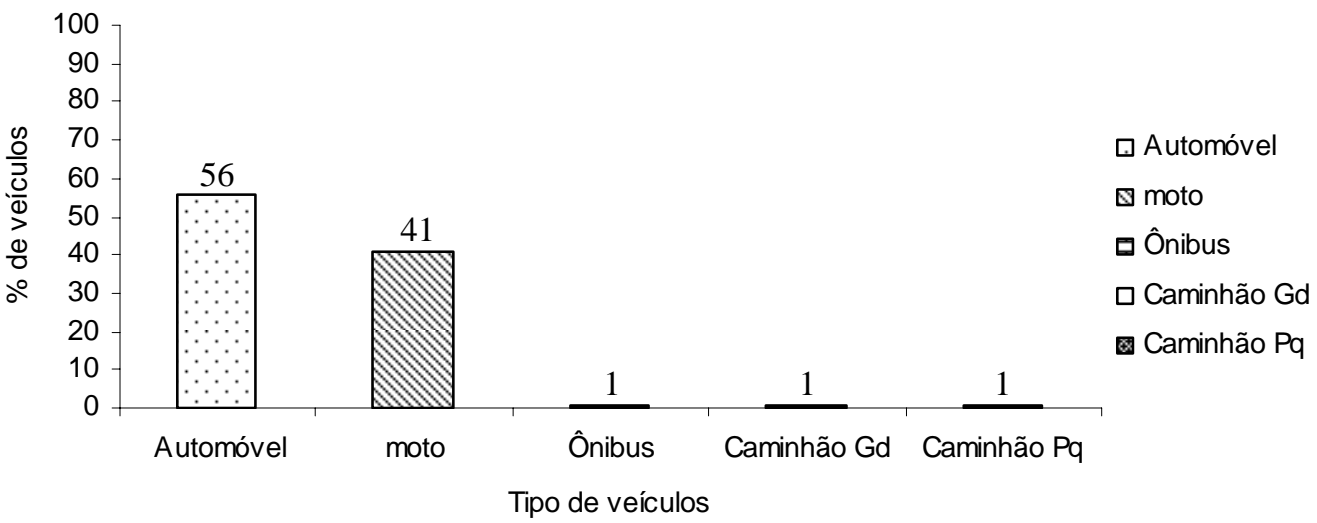

Figura 5.11 - Gráfico da distribuição dos veículos motorizados na Av. General Athayde Teive no período de pico. 


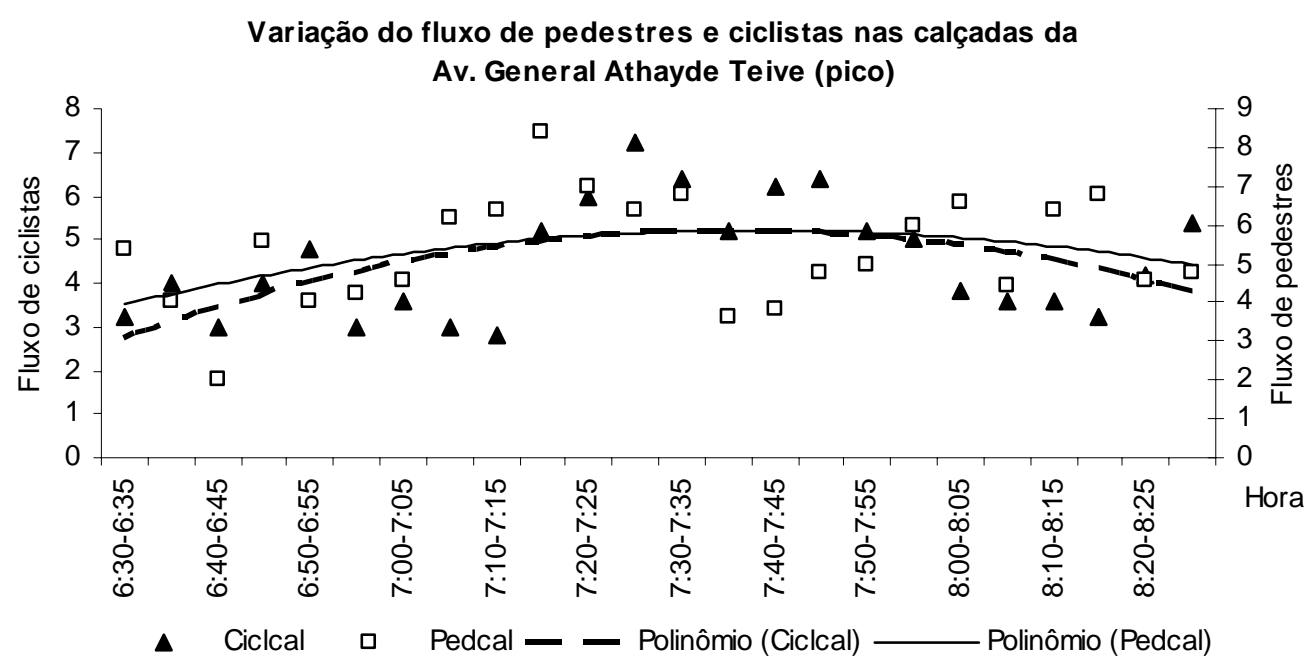

Figura 5.12 - Gráfico da comparação do fluxo de Pedestres e ciclistas sobre as calçadas na Av. General Athayde Teive no período de pico.

Distribuição dos veículos motorizados na

Av. General Athayde Teive (entre-picos)

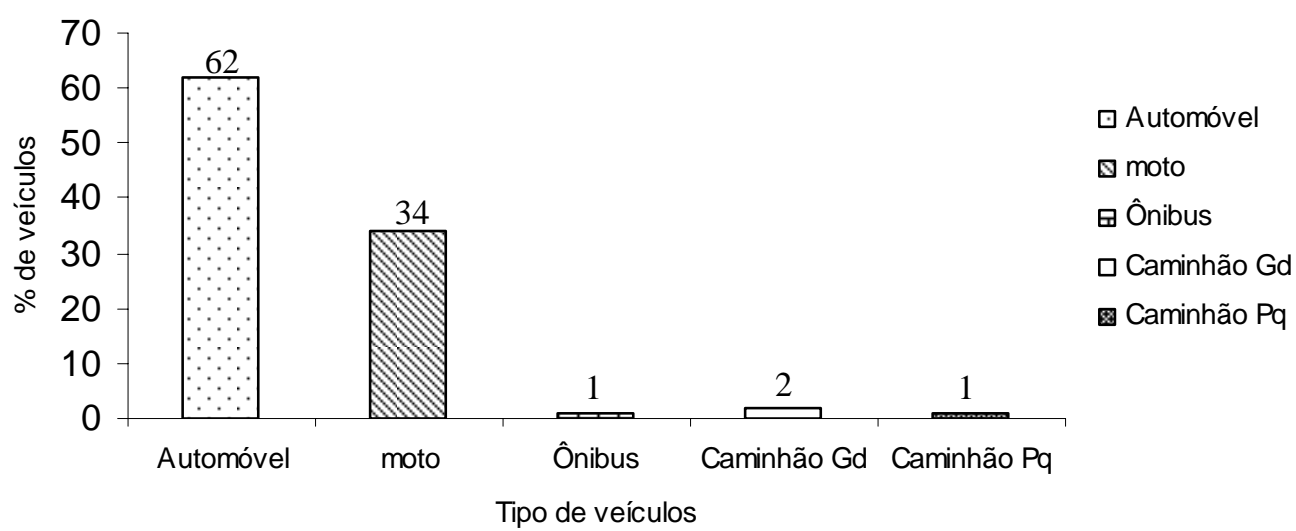

Figura 5.13 - Gráfico da distribuição dos veículos motorizados na Av. General Athayde Teive no período entre-picos. 


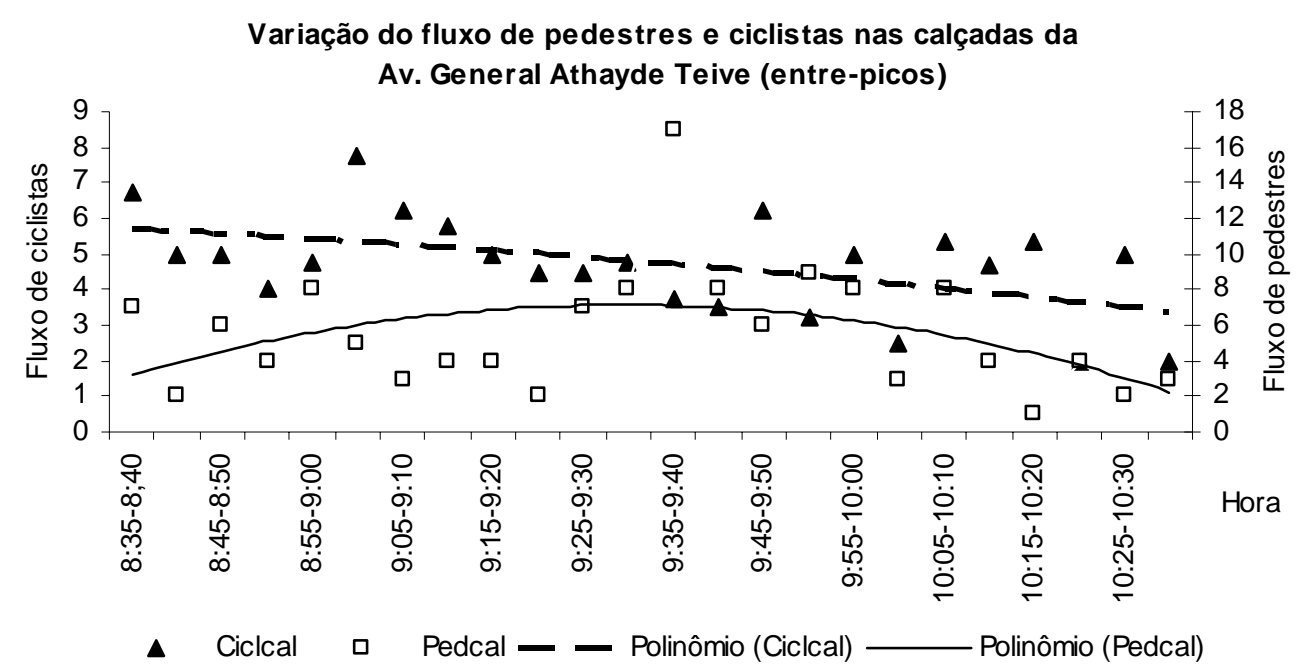

Figura 5.14 - Gráfico da comparação do fluxo de Pedestres e ciclistas sobre as calçadas na Av. General Athayde Teive no período entre-picos.

\section{Av. Brigadeiro Eduardo Gomes}

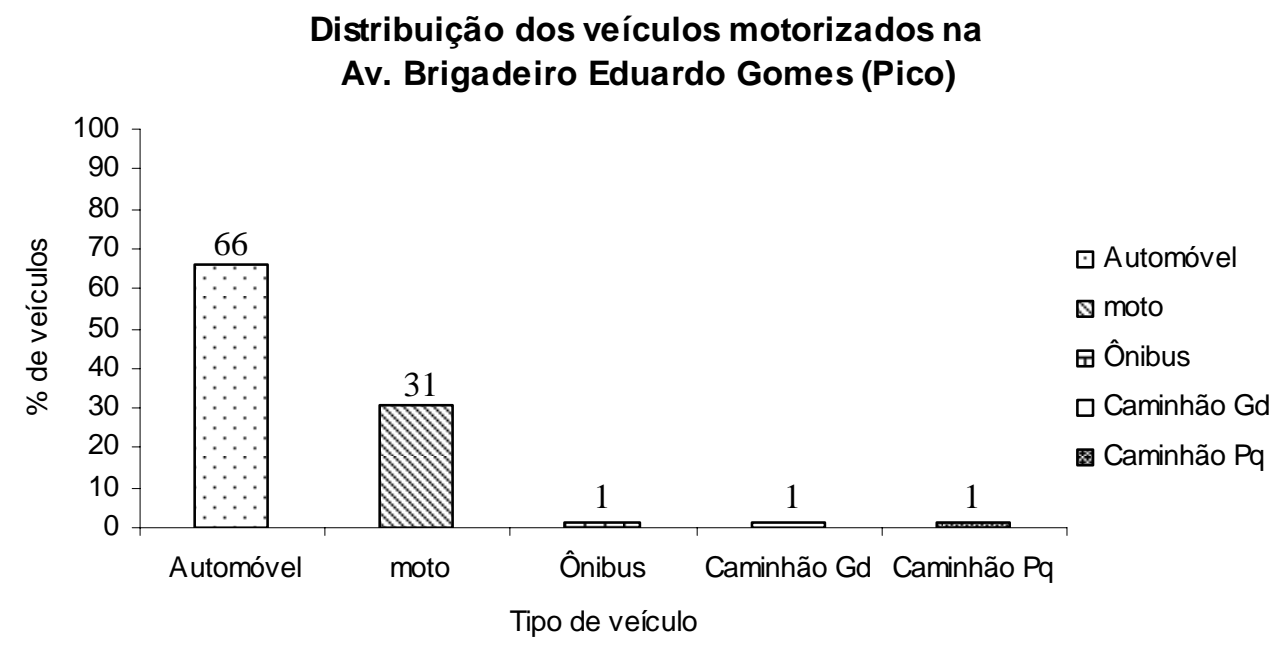

Figura 5.15 - Gráfico da distribuição dos veículos motorizados na Av. Brigadeiro Eduardo Gomes no período de pico. 


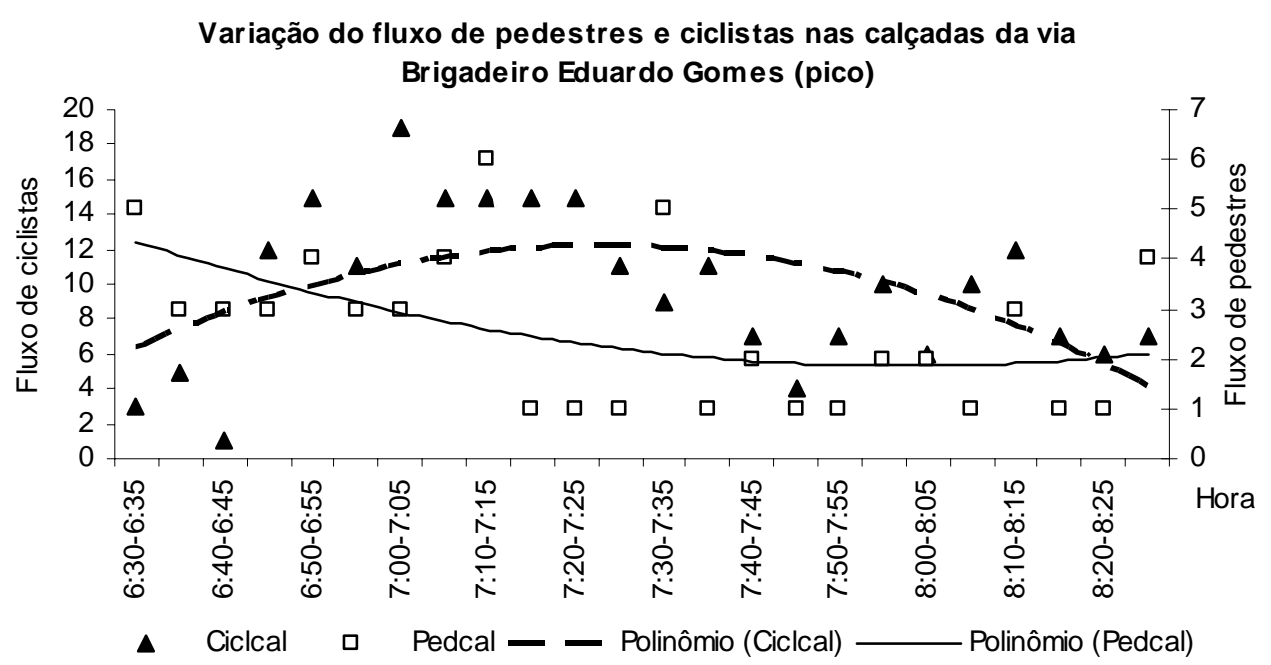

Figura 5.16 - Gráfico da comparação do fluxo de Pedestres e ciclistas sobre as calçadas na Av. Brigadeiro Eduardo Gomes no período de pico.

Nota-se que as variações de comportamento dos ciclistas compromete a qualidade de deslocamento dos pedestres que é refletida pela maior ou menor satisfação desses últimos. Com isso, pode-se dizer que a satisfação dos pedestres foi maior no período entre-picos, onde se verifica uma menor tendência dos ciclistas ocuparem as calçadas. Nas figuras abaixo são mostradas as variações da tendência de satisfação dos pedestres em função da ocupação das calçadas pelos ciclistas, para cada uma das vias avaliadas nesta pesquisa. 


\section{Av. Mário Homem de Mello}

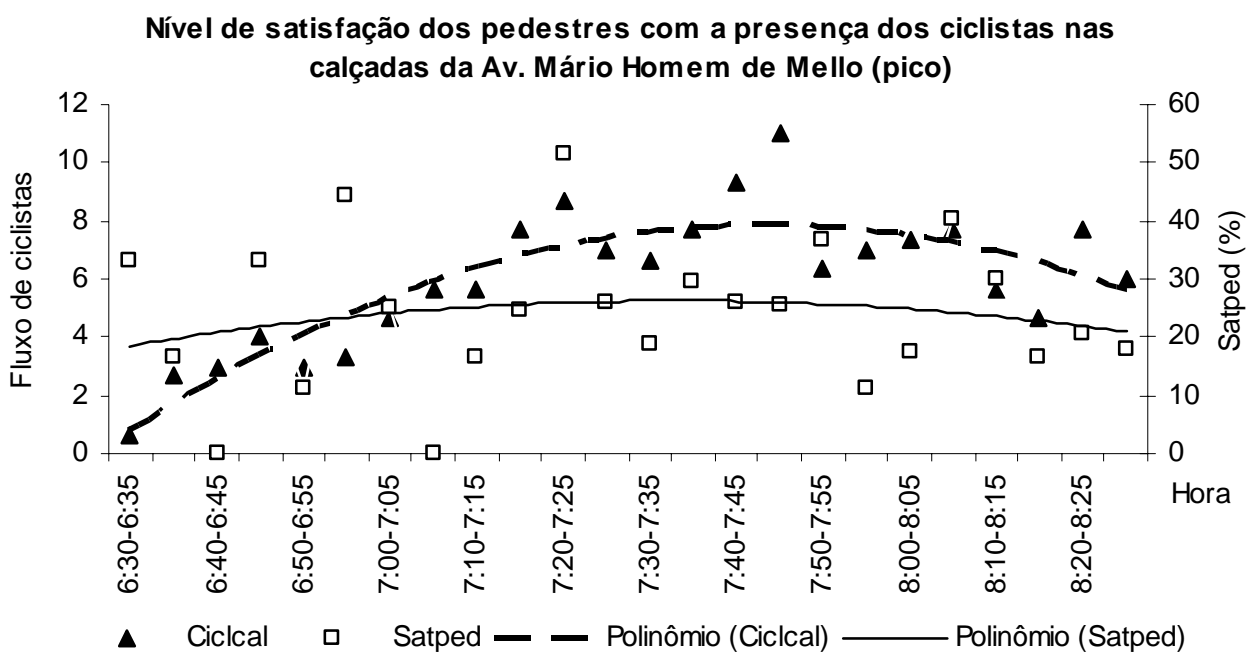

Figura 5.17 - Gráfico do nível de satisfação dos pedstres em função da ocupação das calçadas pelos ciclistas no período de pico.

Nível de satisfação dos pedestres com a presença dos ciclistas nas calçadas da Av. Mário Homem de Mello (entre-picos)

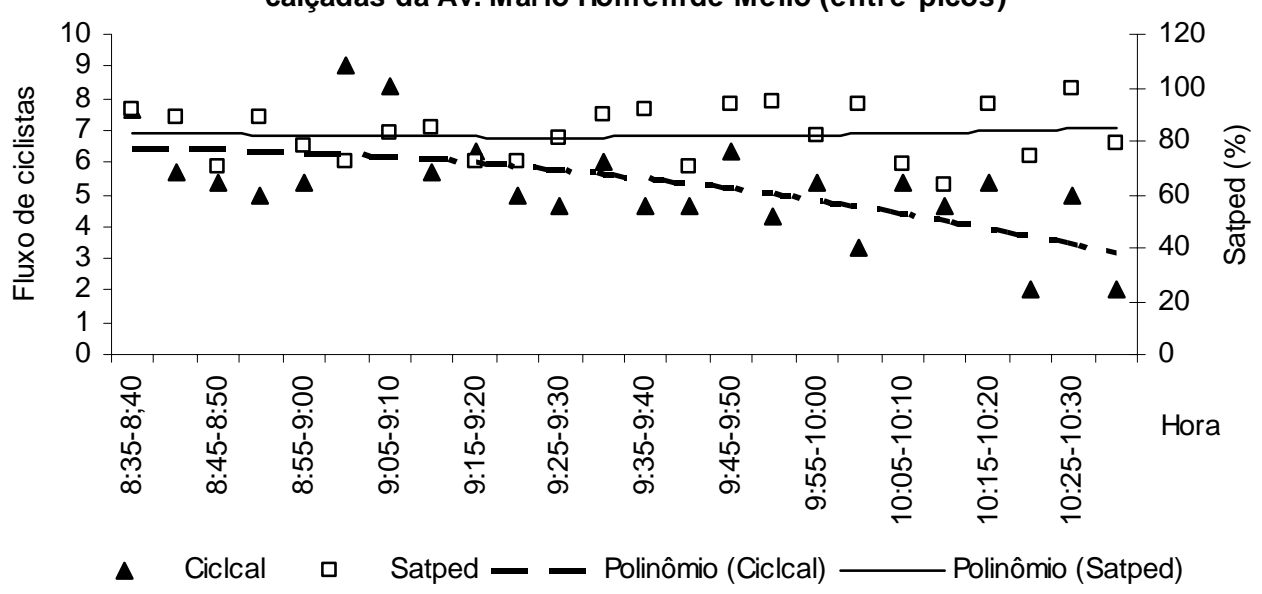

Figura 5.18 - Gráfico do nível de satisfação dos pedstres em função da ocupação das calçadas pelos ciclistas no período entre-picos. 


\section{Av. General Athayde Teive}

Nível de satisfação dos pedestres com a presença dos ciclistas nas calçadas da Av. General Athayde Teive (pico)

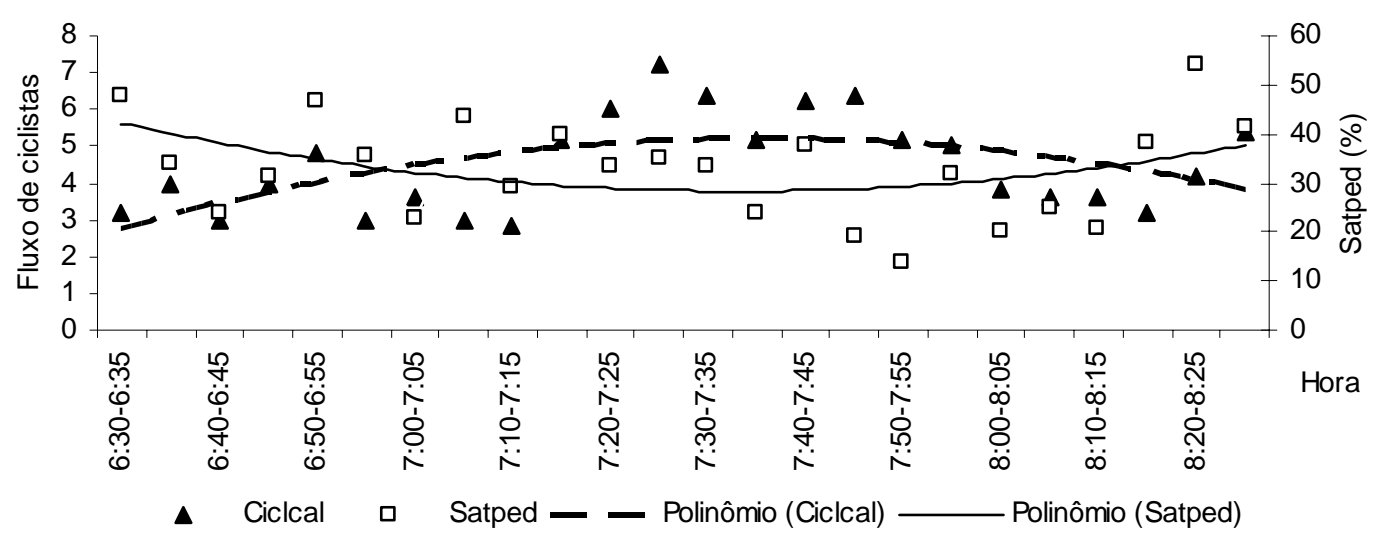

Figura 5.19 - Gráfico do nível de satisfação dos pedstres em função da ocupação das calçadas pelos ciclistas no período de pico.

Nível de satisfação dos pedestres com a presença dos ciclistas nas calçadas da Av. General Athayde Teive (entre-picos)

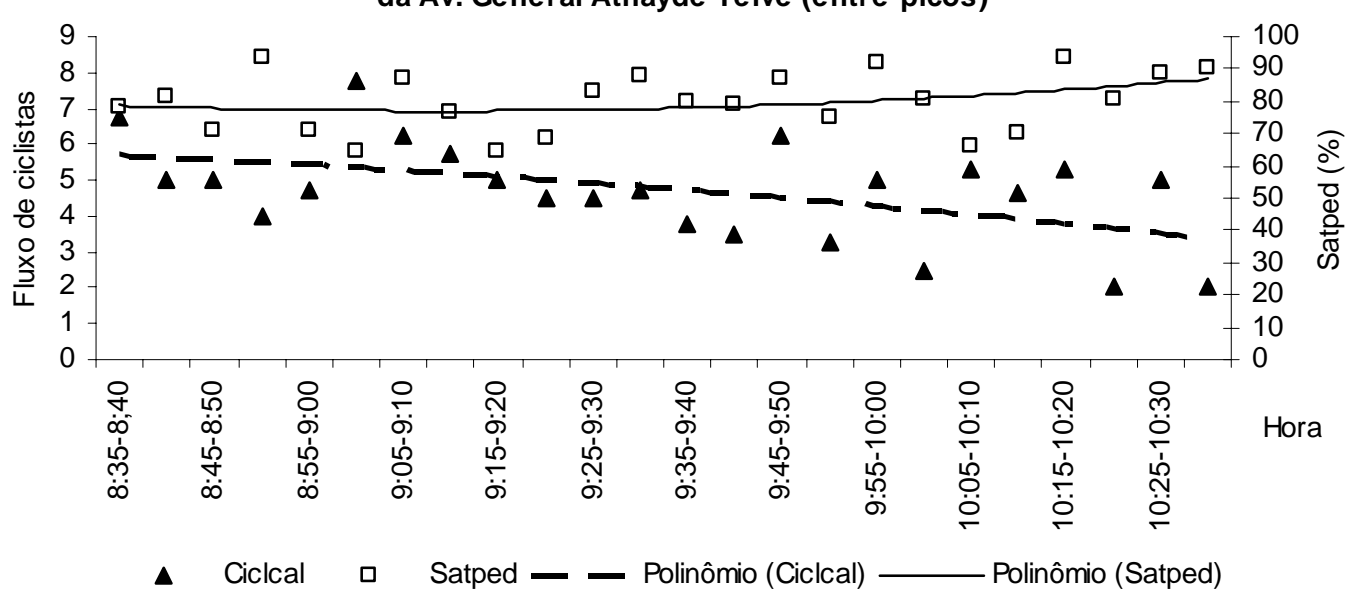

Figura 5.20 - Gráfico do nível de satisfação dos pedstres em função da ocupação das calçadas pelos ciclistas no período entre-picos. 


\section{Av. Brigadeiro Eduardo Gomes}

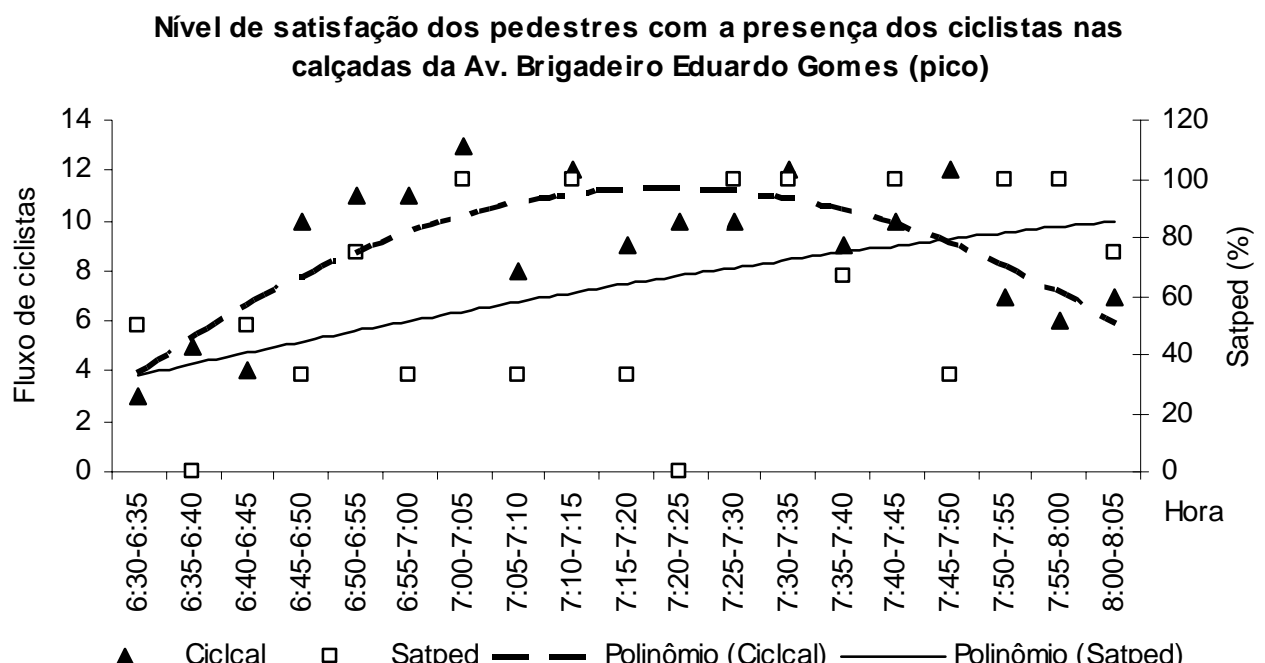

Figura 5.21 - Gráfico do nível de satisfação dos pedstres em função da ocupação das calçadas pelos ciclistas no período de pico.

Convém destacar, que as contagens na Av. Brigadeiro Eduardo Gomes foram realizadas apenas no período de pico, devido ao número bastante reduzido de pedestres e ciclistas na calçada dessa via, no período entre-picos. Tal fato pode ser explicado por ser a Av. Brigadeiro Eduardo Gomes a única via, das três observadas, que não faz a ligação bairro-centro.

A partir dos gráficos apresentados neste capítulo, pode-se ter uma idéia do perfil das vias estudadas. Fica aparente que à medida que ocorre um aumento no fluxo de veículos motorizados nas vias, há também um acréscimo no número de ciclistas que utilizam as calçadas, e conseqüentemente, uma redução do nível de satisfação dos pedestres.

Entretanto, a perda de qualidade nos deslocamentos realizados pelos pedestres pode estar relacionada também com os aspectos físicos e geométricos de 
uma determinada via e não apenas com os operacionais. Por este motivo, a fim de identificar melhor quais os parâmetros que têm maior importância no comportamento dos pedestres, quando estes se deslocam sobre as calçadas de uma via, decidiu-se avaliar o nível de satisfação destes usuários, combinando todos os aspectos acima mencionados (operacional, físico e geométrico) de uma via. Para este propósito utilizou-se a técnica da árvore de decisão. 


\section{Capítulo 6}

\section{DADOS E PROCESSAMENTO}

\subsection{INTRODUÇÃO}

Neste capítulo são, inicialmente, apresentadas e comentadas as variáveis utilizadas para caracterizar as condições operacionais, físicas e geométricas das vias avaliadas nesta pesquisa. É descrito o processo para a elaboração do conjunto de dados, bem como as adaptações feitas ao mesmo, a partir da inclusão de novas variáveis.

A partir do conjunto de dados, são apresentados os resultados obtidos pela técnica da árvore de decisão, ou seja, são definidas as variáveis que têm maior influência no nível de satisfação dos pedestres. Por fim, é elaborado um modelo para dimensionar calçadas, considerando o nível de satisfação dos pedestres, aplicando a técnica de regressão robusta $\mathrm{mm}$. Ambas as técnicas citadas estão contidas no programa S-Plus 6.1.

\subsection{PROCESSAMENTO DOS DADOS}

Conforme descrito no Capítulo 5, desta pesquisa, a perda de qualidade nos deslocamentos realizados pelos pedestres, sobre as calçadas, pode estar relacionada 
também com os aspectos físicos e geométricos de uma determinada via e não apenas com os operacionais. Por este motivo, nesta pesquisa foi gerado um conjunto de dados contendo variáveis que pudessem refletir as três condições (operacional, física e geométrica) de uma via.

Para refletir a parte operacional da via, foram definidos os seguintes fluxos: pedestres (sobre a calçada e fora da calçada), ciclistas (nos bordos da via e sobre a calçada), automóveis, motocicletas, ônibus, caminhão grande e caminhão pequeno. O tráfego foi avaliado de forma classificada, a fim de investigar se algum veículo, como por exemplo, o ônibus (por transitar mais próximo aos bordos da via), tem maior influência em deslocar os ciclistas para as calçadas de uma via.

As condições geométricas da via foram definidas pelas seguintes variáveis: número de faixas de rolamento, largura das faixas de rolamento e largura efetiva das calçadas. As duas primeiras variáveis foram utilizadas para verificar a influência na decisão dos ciclistas, sujeitos ao tráfego, utilizarem ou não as calçadas de uma via. Utilizando-se diferentes larguras efetivas de calçadas, procurou-se avaliar a influência desta variável no deslocamento de pedestres, sujeitos às condições operacionais, físicas e geométricas de uma via.

Convém destacar, que a consideração dos aspectos físicos da via - como postes de iluminação, orelhões, lixeiras, etc. - foi feita a partir da definição de cada uma das larguras efetivas utilizadas nesta pesquisa, uma vez que, o posicionamento de tais equipamentos urbanos em uma calçada causa a redução da seção destinada à circulação dos pedestres.

Após a definição das variáveis, foi realizada a coleta e o agrupamento das mesmas em um conjunto de dados. Com isso, elaborou-se uma planilha onde foram apresentadas todas as informações citadas anteriormente, mais aquelas provenientes das pesquisas de opinião, realizadas com os pedestres nas calçadas, conforme descrito no Capítulo 4. 
Como adaptações feitas no conjunto de dados original, foram acrescentadas colunas referentes às seguintes variáveis: número total de ciclistas na via (Cicltot), número total de caminhões (sem distinção entre grandes e pequenos) (Cam), somatória de caminhões e ônibus (Cambus), número total de pedestres na via (Pedtot), número de pedestres na calçada por metro de calçada (Pedcal/m), número total de pedestres na via por metro de calçada (Pedtot $/ \mathrm{m})$, número de ciclistas na calçada por metro de calçada (Ciclcal/m), número total de ciclistas na via por metro de calçada (Cicltot $/ \mathrm{m})$, número de pedestres fora da calçada por metro de calçada (Pedfora/m), número total de ciclistas na via por número total de pedestres na via (Cicltot/pedt) e o número de ciclistas na calçada por número total de pedestres na via (Ciclcal/pedt). Um exemplo do novo conjunto de dados com suas respectivas adaptações pode ser observado no apêndice $A$ desta pesquisa.

\subsection{OBTENÇÃO DOS RESULTADADOS DA ÁRVORE DE DECISÃO}

A partir do conjunto de dados elaborado, utilizou-se o programa S-Plus 6.1 para gerar várias árvores de decisão, objetivando a definição dos parâmetros que têm maior influência no comportamento do pedestre e prejudicam o seu deslocamento sobre a calçada, considerando todos os aspectos geométricos, funcionais e operacionais de uma via urbana.

A árvore de decisão, que apresentou o melhor resultado, indicou como parâmetros mais relevantes e que devem influenciar no comportamento dos pedestres nas calçadas: o fator pico, a largura efetiva da calçada (Lef), o número total de ciclistas na calçada da via dividido pelo número total de pedestres na via (Ciclcal/pedt), o número total de ciclistas na calçada por metro de calçada (Ciclical/m), o número total 
de ciclistas na via (Ciclitot), o número total de pedestres na calçada por metro de calçada (Pedcal $/ \mathrm{m}$ ) e o número total de pedestres na calçada (Pedcal).

A Figura 6.1 apresenta o gráfico da árvore em questão. Para um melhor entendimento dos resultados obtidos, além da representação gráfica, é apresentado na tabela 6.1 um resumo do relatório da árvore de decisão, emitido pelo programa SPlus 6.1. Nesta tabela podem ser visualizadas de uma forma mais simples as variáveis descritas no parágrafo anterior, o número de observações contidas em cada nó, a porcentagem de pedestres satisfeitos em cada nó e a porcentagem de pedestres insatisfeitos em cada nó. As linhas sombreadas da tabela 6.1 representam os nós terminais da árvore de decisão. Outras características da árvore de decisão são as seguintes:

- Número mínimo de observações na folha = 20

- Número mínimo de observações para cada divisão de nó = 40

- desvio mínimo = 0,01 


\section{LEGENDA}

Lef $=$ largura efetiva da calçada, em metros

Ciclcal $/ m=$ no ciclistas na calçada metro (largura) de calçada

Ciclcal/pedt $=\frac{\text { no ciclistas na calçada }}{\text { no pedestres na via }}$
Pedcal $=$ no de pedestres na calçada

Pedcal $/ m=\frac{\text { no de pedestres na calçada }}{\text { metro (largura) de calçada }}$

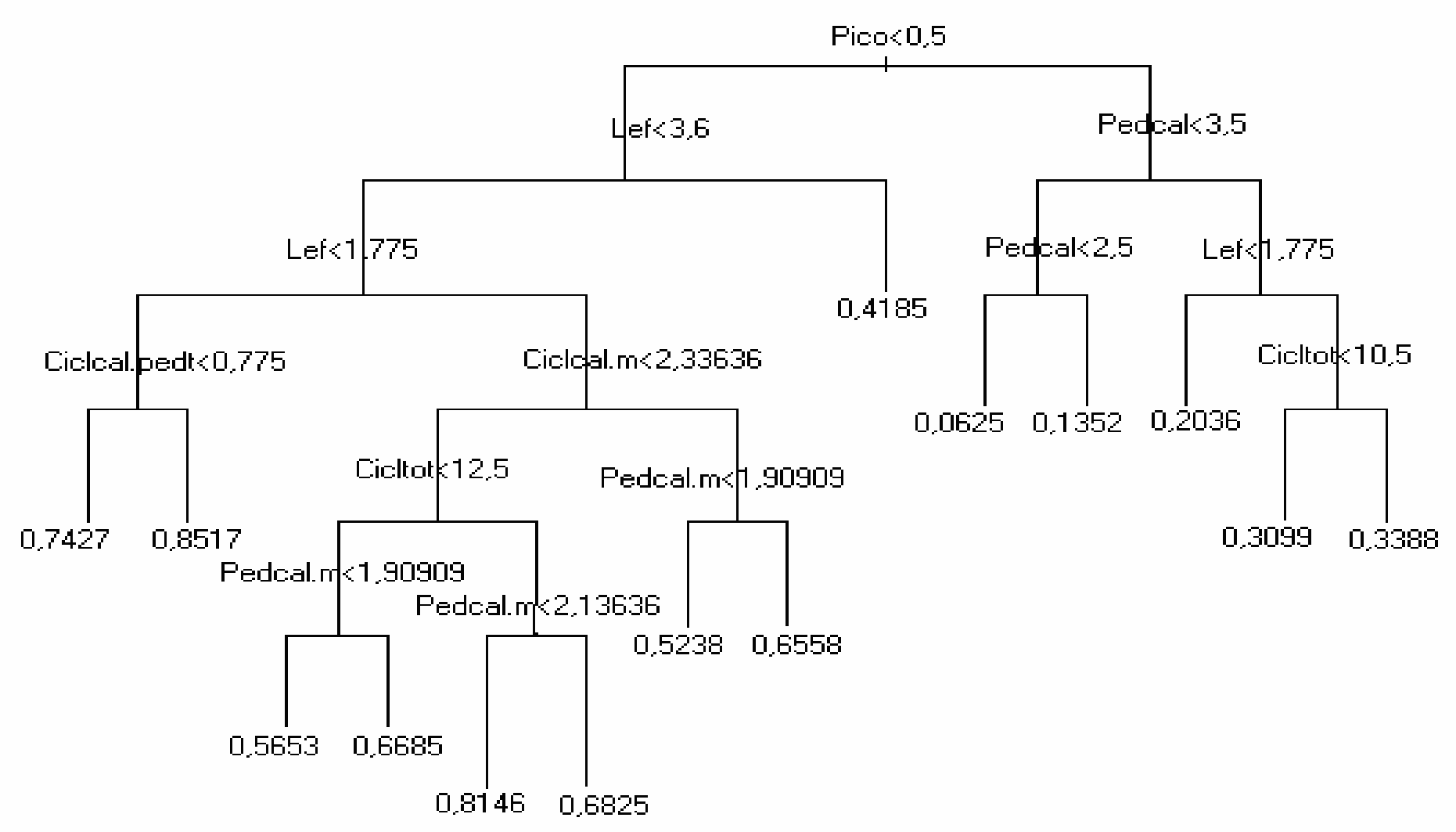

Figura 6.1 - Representaçấo gráfica da árvore de decisấo 


\begin{tabular}{|c|c|c|c|c|c|c|c|c|c|c|}
\hline & & & & & & Nó & & Pessoas & $\begin{array}{c}(\%) \\
\text { Satisfeito }\end{array}$ & $\begin{array}{c}(\%) \\
\text { Insatisfeito } \\
\end{array}$ \\
\hline & & & & & & 1 & Nó raiz & 375 & 46 & 54 \\
\hline \multirow{17}{*}{ Pico<0.5 } & & & & & & 2 & Pico $<0.5$ & 265 & 33 & 67 \\
\hline & \multirow{15}{*}{ Lef $<3.6$} & & & & & 4 & Lef $<3.6$ & 227 & 31 & 69 \\
\hline & & \multirow{3}{*}{ Lef $<1.775$} & & & & 8 & Lef $<1.775$ & 71 & 23 & 77 \\
\hline & & & Ciclcal/pedt $<0.775$ & & & 16 & Ciclcal/pedt $<0.775$ & 36 & 26 & 74 \\
\hline & & & Ciclcal/pedt $>0.775$ & & & 17 & Ciclcal/pedt $>0.775$ & 35 & 15 & 85 \\
\hline & & \multirow{11}{*}{ Lef $>1.775$} & & & & 9 & Lef $>1.775$ & 156 & 35 & 65 \\
\hline & & & \multirow{7}{*}{ Ciclcal $/ \mathrm{m}<2.33636$} & & & 18 & Ciclcal/m<2.33636 & 102 & 32 & 68 \\
\hline & & & & \multirow{3}{*}{ Cicltot $<12.5$} & & 36 & Cicltot $<12.5$ & 54 & 37 & 63 \\
\hline & & & & & Pedcal/m<1.90909 & 72 & Pedcal/m<1.90909 & 28 & 44 & 56 \\
\hline & & & & & Pedcal/m>1.90909 & 73 & Pedcal/m>1.90909 & 26 & 34 & 66 \\
\hline & & & & \multirow{3}{*}{ Cicltot $>12.5$} & & 37 & Cicltot $>12.5$ & 48 & 28 & 72 \\
\hline & & & & & Pedcal $/ \mathrm{m}<2.13636$ & 74 & Pedcal/m<2.13636 & 24 & 19 & 81 \\
\hline & & & & & Pedcal $/ m>2.13636$ & 75 & Pedcal/m>2.13636 & 24 & 32 & 68 \\
\hline & & & \multirow{3}{*}{ Ciclcal $/ m>2.33636$} & & & 19 & Ciclcal/m>2.33636 & 54 & 39 & 61 \\
\hline & & & & Pedcal/m<1.90909 & & 38 & Pedcal/m<1.90909 & 23 & 48 & 52 \\
\hline & & & & Pedcal/m>1.90909 & & 39 & Pedcal/m>1.90909 & 31 & 35 & 65 \\
\hline & Lef $>3.6$ & & & & & 5 & Lef $>3.6$ & 38 & 59 & 41 \\
\hline \multirow{9}{*}{ Pico $>0.5$} & & & & & & 3 & Pico $>0.5$ & 110 & 77 & 23 \\
\hline & \multirow{3}{*}{ PedCal<3.5 } & & & & & 6 & PedCal<3.5 & 47 & 91 & 9 \\
\hline & & PedCal $<2.5$ & & & & 12 & PedCal<2.5 & 24 & 94 & 6 \\
\hline & & PedCal $>2.5$ & & & & 13 & PedCal>2.5 & 23 & 87 & 13 \\
\hline & \multirow{5}{*}{ PedCal $>3.5$} & & & & & 7 & PedCal>3.5 & 63 & 72 & 28 \\
\hline & & Lef $<1.775$ & & & & 14 & Lef $<1.775$ & 23 & 80 & 20 \\
\hline & & \multirow{3}{*}{ Lef $>1.775$} & & & & 15 & Lef $>1.775$ & 40 & 68 & 32 \\
\hline & & & Cicltot $<10.5$ & & & 30 & Cicltot $<10.5$ & 20 & 70 & 30 \\
\hline & & & Cicltot $>10.5$ & & & 31 & Cicltot $>10.5$ & 20 & 67 & 33 \\
\hline
\end{tabular}


É razoável que nos resultados obtidos pela árvore apresentada acima apareçam variáveis relacionadas aos ciclistas, pois, conforme demonstrado nesta pesquisa, há um considerável número de conflitos sobre as calçadas envolvendo ciclistas e pedestres. Tal fato deve influenciar na qualidade dos deslocamentos desses últimos, ou seja, quanto maior for a presença de ciclistas nas calçadas mais afetado será o nível de satisfação dos pedestres.

Com base nas respostas da árvore, acredita-se ainda que, havendo um incremento de ciclistas na via, haverá também mais ciclistas que tenderão a ocupar a calçada da mesma. Esta tendência, além de observada com o auxílio do minerador de dados pode ser visualizada também nas Figuras 6.2 e 6.3 abaixo.

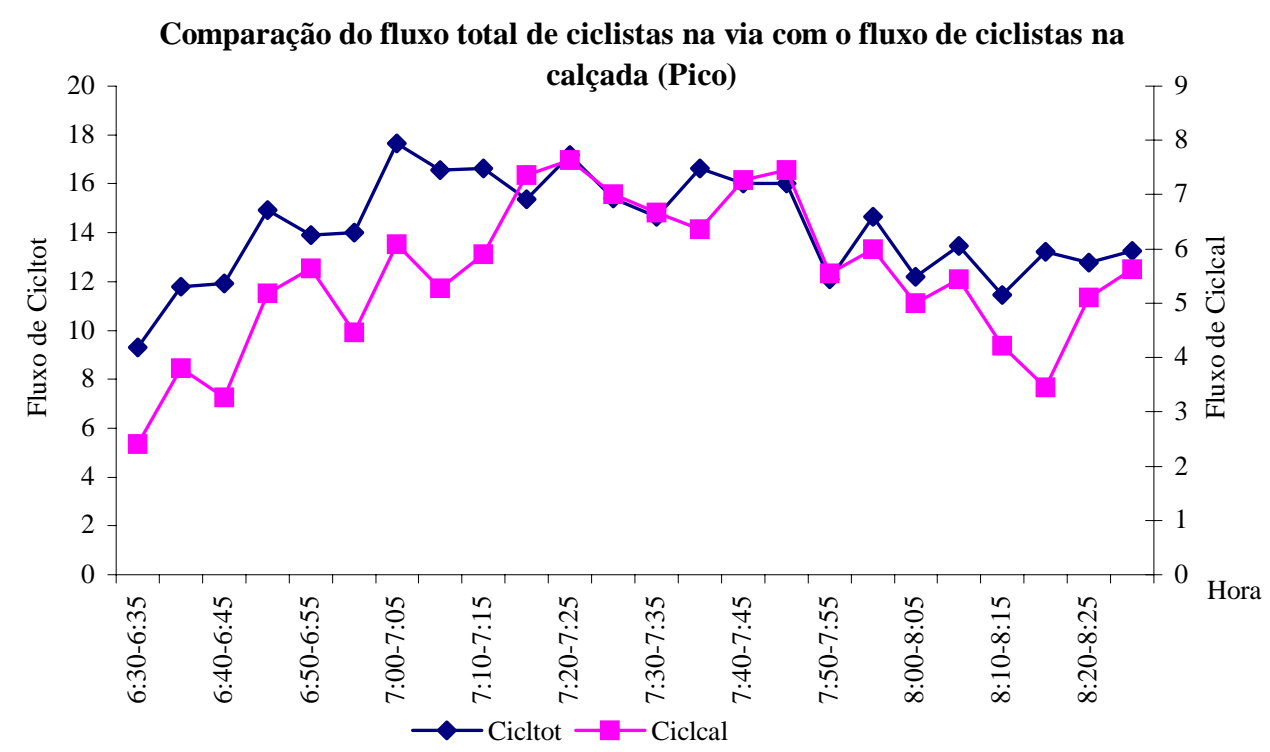

Figura 6.2 - Comparação do fluxo total de ciclistas na via com o fluxo de ciclistas na calçada da mesma no período de pico. 


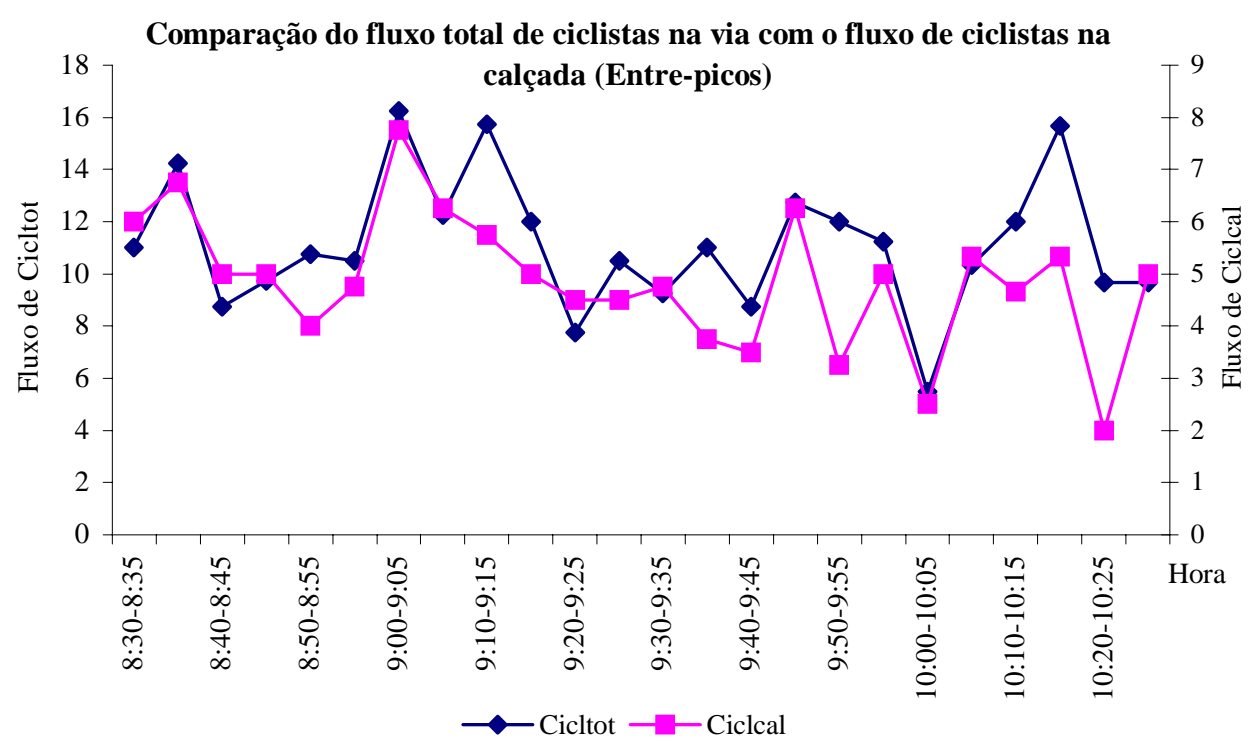

Figura 6.3 - Comparação do fluxo total de ciclistas na via com o fluxo de ciclistas na calçada da mesma no período entre-picos.

Verificando-se os nós 16 e 17; 36 e 37; 30 e 31 da árvore apresentada, observa-se a influência dos ciclistas no nível de satisfação dos pedestres. Convém destacar que ao analisar os nós 18 e 19 a mesma tendência de comportamento não foi encontrada.

Entretanto, deve-se considerar que a tomada de decisão, feita por um usuário, a partir da técnica da árvore de decisão, deve considerar a hierarquia das variáveis apresentadas pela árvore, bem como, a tendência do comportamento de grupos, sujeitos a essas variáveis. Portanto, torna-se mais importante o comportamento geral da árvore do que o comportamento em nós isolados.

As outras variáveis, destacadas pela árvore em questão com o propósito de evidenciar a satisfação dos pedestres, confirmam a proposta de outros estudos passados, como o do HCM (2000), por exemplo, em que a largura efetiva e o fluxo de pedestres na calçada têm uma influência considerável no nível de serviço de tal infraestrutura. 
Assim, observando-se os pares de nós 72 e 73; 38 e 39; 6 e 7 e 12 e 13, percebe-se que quanto maior o fluxo de pedestres na calçada maior será a insatisfação destes. Entretanto, o par de nós 74 e 75 não reflete o exposto acima, porém, conforme descrito anteriormente, deve-se considerar o comportamento geral da árvore e não apenas nós isolados.

Com relação à largura efetiva da calçada, nota-se pelos pares de nós 4 e 5, e 8 e 9, que quanto maior for o valor da largura efetiva de calçada, menor será a insatisfação dos pedestres. Porém, no par de nós 14 e 15 esta relação não se verifica. Pode-se atribuir isto não só ao fato do maior número de pedestres entrevistados estarem contidos no nó 15 (quase o dobro do nó 14), como também à maior freqüência de ciclistas na calçada encontrada no referido nó. Assim, percebe-se que calçadas com larguras efetivas maiores, tornam-se mais atrativas para a circulação dos ciclistas, conseqüentemente, prejudicando os deslocamentos dos pedestres. Nas tabelas abaixo são apresentadas as freqüências dos pedestres e ciclistas na calçada presentes nos nós em questão.

Tabela 6.2 - Comparação do número de pedestres na calçada entre os nós 14 e 15.

\begin{tabular}{|c|c|c|c|}
\hline \multicolumn{2}{|c|}{ Pedestres na calçada nó 14 } & \multicolumn{2}{c|}{ Pedestres na calçada nó 15 } \\
\hline $\begin{array}{c}\text { Quantidade de } \\
\text { pedestres }\end{array}$ & $\begin{array}{c}\text { Número de } \\
\text { observações }\end{array}$ & $\begin{array}{c}\text { Quantidade de } \\
\text { pedestres }\end{array}$ & $\begin{array}{c}\text { Número de } \\
\text { observações }\end{array}$ \\
\hline 4 & 7 & 4 & 8 \\
\hline 5 & 10 & 5 & 5 \\
\hline 6 & 3 & 6 & 4 \\
\hline 7 & 1 & 7 & 11 \\
\hline 10 & 2 & 8 & 2 \\
\hline & & 9 & 2 \\
\hline & & 10 & 1 \\
\hline
\end{tabular}


Tabela 6.3 - Comparação do número de ciclistas na calçada entre os nós 14 e 15.

\begin{tabular}{|c|c|c|c|}
\hline \multicolumn{2}{|c|}{ Ciclistas na calçada nó 14 } & \multicolumn{2}{c|}{ Ciclistas na calçada nó 15 } \\
\hline $\begin{array}{c}\text { Quantidade de } \\
\text { ciclistas }\end{array}$ & $\begin{array}{c}\text { Número de } \\
\text { observações }\end{array}$ & $\begin{array}{c}\text { Quantidade de } \\
\text { ciclistas }\end{array}$ & $\begin{array}{c}\text { Número de } \\
\text { observações }\end{array}$ \\
\hline 1 & 3 & 0 & 2 \\
\hline 2 & 1 & 1 & 7 \\
\hline 3 & 3 & 2 & 2 \\
\hline 4 & 5 & 3 & 9 \\
\hline 5 & 6 & 4 & 3 \\
\hline 6 & 1 & 5 & 3 \\
\hline 7 & 3 & 6 & 4 \\
\hline 8 & 1 & 7 & 1 \\
\hline & & 9 & 1 \\
\hline
\end{tabular}

Pelo exposto até o presente momento, e considerando os resultados apresentados pela árvore de decisão, percebe-se que a qualidade dos deslocamentos realizados pelos pedestres sobre as calçadas de uma via urbana que não possui uma infra-estrutura destinada à circulação de bicicletas é influenciada pelo fluxo de ciclistas, pelo fluxo de pedestres que atravessa uma determinada seção de calçada e pela respectiva largura efetiva da mesma.

Com o intuito de atingir o objetivo principal desta pesquisa, após definidas as variáveis que têm maior influência na qualidade dos deslocamentos dos pedestres; será desenvolvido um modelo para dimensionar calçadas em vias urbanas. O modelo deverá levar em conta o nível de satisfação dos pedestres e as variáveis indicadas pela árvore de decisão, que representam as características geométricas e operacionais das vias estudadas. 


\subsection{MODELO PARA DIMENSIONAMENTO DE CALÇADAS EM VIAS URBANAS}

Como ferramenta auxiliar para o desenvolvimento do modelo proposto nesta pesquisa utilizou-se a regressão robusta $\mathrm{mm}$, contida no programa S-Plus 6.1. Para a obtenção de um modelo coerente e representativo, foram realizados vários tipos de combinações das variáveis apontadas pela árvore de decisão como sendo as mais relevantes para explicar o nível de satisfação dos pedestres.

Usando esse procedimento, vários modelos foram gerados. Entretanto, e como precaução, teve-se o cuidado de verificar não só os resultados estatísticos de cada um, no tocante à sua representatividade com relação ao fenômeno estudado, mas também, procurou-se observar o quão significativos são os coeficientes dos modelos obtidos.

Tal cuidado se faz necessário, pois com a utilização do programa S-Plus 6.1, o próprio usuário define valores para os coeficientes e expoentes de cada variável. Desta forma, podem ser obtidas variáveis que são estatisticamente significantes, porém, não traduzem o que realmente ocorre em uma via, ou seja, não são adequadas para traduzir as mudanças que ocorrem na satisfação dos pedestres em deslocamento sobre as calçadas.

O melhor modelo obtido, para traduzir a satisfação dos pedestres, é o modelo I, abaixo apresentado.

\section{Modelo I}

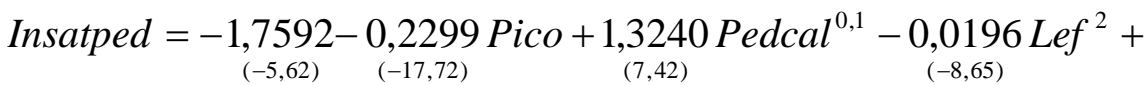

$$
\begin{aligned}
& +0,5447 \text { Cicltot }^{0,1}
\end{aligned}
$$


onde:

Insatped $\rightarrow$ nível de insatisfação dos pedestres (\%);

Pico $\rightarrow$ período da observação, nesta pesquisa considerou-se os seguintes valores: 0 para o período de pico e 1 para o entre-picos;

Pedcal $\rightarrow$ número total de pedestres sobre a calçada observada (ped/5 min);

Lef $\rightarrow$ largura efetiva da calçada observada $(m)$;

Cicltot $\rightarrow$ número total de ciclistas na via em questão (Cicltot/5 min)

Observa-se que no modelo I, a insatisfação do pedestre é traduzida pelo intercepto do modelo e pelas seguintes variáveis: a variável categórica Pico/Entrepicos (dependendo do valor adotado; 0 e 1, respectivamente); o número total de pedestres sobre a calçada observada (Pedcal); a largura efetiva da calçada observada (Lef) e o número total de ciclistas na via em questão (Cicltot).

Percebe-se que o modelo I proposto é coerente, pois, tanto as variáveis que influenciam a satisfação do pedestre como os respectivos sinais dessas estão em consonância com os resultados obtidos por estudos passados, como por exemplo, o HCM (2000). Assim, pode ser verificado no modelo que quanto maior for o número de pedestres na calçada, maior será a insatisfação dos pedestres e quanto maior for a largura efetiva da calçada, menor será a insatisfação dos pedestres.

Observa-se também, no modelo, que no período de pico há uma tendência de a insatisfação dos pedestres ser maior do que no período entre-picos. Conforme comentado anteriormente, e demonstrado nas Figuras 6.2 e 6.3, quanto maior for o número total de ciclistas na via, maior será o número de ciclistas na calçada, causando a redução da satisfação dos pedestres. Pode-se afirmar também que a passagem de 1 ciclistas/minuto na via provoca um incremento de 50\% na insatisfação dos pedestres. 
Abaixo de cada coeficiente do modelo é destacado o valor da estatística t, convém ressaltar que o valor "Pr" para todos os valores da estatística t, considerando um intervalo de confiança de $10 \%$, foi igual a 0 (zero), indicando que todos os coeficientes pertencentes ao modelo são significativos. O valor de $\mathrm{R}^{2}$ para o modelo I foi de $70 \%$.

Portanto, a partir do valor da estatística t, pode-se afirmar que as variáveis que mais influenciam na satisfação do pedestre são as seguintes, em ordem decrescente: período pico/entre-picos; largura efetiva da calçada; número total de pedestres sobre a calçada observada e número total de ciclistas na via em questão. Convém destacar que esta ordem de importância é compatível com aquela apresentada pela árvore de decisão. 


\section{Capítulo 7}

\section{ANÁLISE DOS RESULTADOS}

\subsection{INTRODUÇÃO}

Neste capítulo é mostrada a compatibilidade dos resultados, obtidos pelo modelo proposto nesta pesquisa, com os do HCM (2000), e todas as considerações sob as quais foi efetuada a comparação entre ambos os estudos. Após a verificação da consistência do modelo proposto, é apresentada uma comparação dos resultados deste com os de outros estudos encontrados na bibliografia.

Posteriormente, são apresentadas as fronteiras para os níveis de serviço do modelo proposto, considerando o período de pico/entre picos, o fluxo de pedestres na calçada, a largura efetiva da calçada e o número total de ciclistas na via.

É mostrada uma adaptação do modelo, com o intuito de utilizá-lo para dimensionamento de calçadas em locais onde não existam tais infra-estruturas. Por fim, apresenta-se um nomograma, referente ao modelo proposto, para determinações expeditas em campo. 


\subsection{COMPATIBILIDADE DO MODELO PROPOSTO COM O HCM (2000)}

\subsubsection{CONSIDERAÇÕES SOBRE O MODELO PROPOSTO}

A fim de avaliar a consistência do modelo I proposto nesta pesquisa, procurou-se comparar a coerência existente do nível de insatisfação dos pedestres fornecido pelo modelo, com os níveis de serviço para calçadas sugeridos por outros estudos e encontrados na bibliografia corrente. A primeira comparação feita foi com os níveis de serviço propostos pelo HCM (2000), por se tratar de uma referência muito utilizada para projetos.

Um parâmetro utilizado pelo manual acima citado, para a definição das fronteiras dos seus diferentes níveis de serviço, é o fluxo de pedestres por minuto por metro de largura de calçada (ped/min/m). Na tabela 7.1 podem ser identificados os níveis de serviço sugeridos pelo HCM (2000), com os seus respectivos valores de fronteiras.

Tabela 7.1 - Níveis de serviço propostos pelo HCM (2000).

\begin{tabular}{cc}
\hline Nível de serviço & Pedestre/minuto/metro \\
\hline$A$ & Até 16 \\
\hline$B$ & $16-23$ \\
\hline C & $23-33$ \\
\hline$D$ & $33-49$ \\
\hline$E$ & $49-75$ \\
\hline$F$ & Fluxo congestionado \\
\hline
\end{tabular}

Conforme mostrado neste trabalho, o número total de ciclistas na via interfere no nível de satisfação dos pedestres. Porém, em momento algum o manual do HCM (2000) menciona, na definição dos seus níveis de serviço para calçadas, a influência 
dos ciclistas sobre os deslocamentos dos pedestres. Outro aspecto não mencionado pelo manual citado é a largura efetiva de calçadas, uma vez que a taxa de fluxo, utilizada como fronteira para nível de serviço, considera apenas a unidade metro de largura efetiva da calçada.

Entretanto, supõe-se que a satisfação de cada pessoa que compõe um fluxo de 20 pedestres, e atravessa a seção de uma calçada com 1 metro de largura efetiva, no intervalo de tempo de 1 minuto, não deve ser a mesma caso 60 pedestres tenham que atravessar, no mesmo período de tempo, uma seção de calçada com 3 metros de largura efetiva.

Por este motivo, utilizando o modelo proposto nesta pesquisa, definiu-se o nível de insatisfação média para os pedestres, fazendo-se as seguintes considerações:

\section{a) Largura efetiva da calçada}

Para este atributo foram identificadas na pesquisa de campo 6 diferentes larguras: $0,90 \mathrm{~m}, 1,50 \mathrm{~m}, 2,00 \mathrm{~m}, 2,20 \mathrm{~m}, 2,50 \mathrm{~m}$ e $4,70 \mathrm{~m}$. Entretanto, os resultados da árvore de decisão indicaram como parâmetros para a satisfação dos pedestres, as larguras de $1,77 \mathrm{~m}$ e 3,60m, conforme mostrado na Figura 6.1 .

Portanto, para a definição da insatisfação média dos pedestres, foram considerados os seguintes valores: $1 \mathrm{~m}, 2 \mathrm{~m}, 3 \mathrm{~m}$ e $4 \mathrm{~m}$. Com isso, foram utilizadas larguras efetivas de calçadas de acordo com os parâmetros obtidos pela árvore de decisão, uma vez que os resultados desta consideraram valores abaixo de $1,77 \mathrm{~m}$, entre $1,77 \mathrm{~m}$ e $3,60 \mathrm{~m}$ e acima de $3,60 \mathrm{~m}$. 


\section{b) Pedestres na calçada}

Os valores atribuídos a esta variável, para a determinação da insatisfação média, tiveram como base os fluxos limites de pedestres, sugeridos pelo HCM (2000), porém, como o intervalo das contagens realizadas nesta pesquisa teve a duração de 5 minutos, então, o número de pedestres na calçada utilizado no modelo ora proposto, foi sempre igual ao número de pedestres do HCM (2000) multiplicado por 5 , e este produto, foi multiplicado pela medida da respectiva largura efetiva da calçada em questão, a fim de considerar o fluxo de pedestres por metro de calçada. A tabela abaixo exemplifica o cálculo descrito.

Tabela 7.2 - Exemplo da determinação do $n^{\circ}$ de pedestres na calçada para o modelo proposto, visando a definição da insatisfação média dos pedestres.

\begin{tabular}{cccc}
\hline Nível de Serviço & Largura Efetiva $(\mathrm{m})$ & Fluxo HCM $(2000)$ & Fluxo para o modelo proposto \\
\hline $\mathrm{A}$ & 1 & 16 & $80=(16 \times 5 \times 1)$ \\
\hline $\mathrm{A}$ & 2 & 16 & $160=(16 \times 5 \times 2)$ \\
\hline $\mathrm{A}$ & 3 & 16 & $240=(16 \times 5 \times 3)$ \\
\hline $\mathrm{A}$ & 4 & 16 & $320=(16 \times 5 \times 4)$ \\
\hline
\end{tabular}

\section{c) Número total de ciclistas na via}

Como o HCM (2000) não menciona o parâmetro ciclista para definir as fronteiras dos seus níveis de serviço para calçadas, no modelo proposto foi adotado o valor 0 (zero) para esta variável. 


\subsubsection{COMPARAÇÃO DOS RESULTADOS DO MODELO PROPOSTO COM O HCM (2000)}

A partir das considerações feitas foram calculados, utilizando o modelo proposto nesta pesquisa, valores para a insatisfação dos pedestres tomando como base o fluxo de pedestres sugerido pelo HCM (2000), para cada nível de serviço definido pelo referido manual. Neste cálculo foram consideradas também as variações da largura efetiva da calçada, conforme descrito anteriormente.

As colunas das tabelas a seguir, apresentam da esquerda para a direita, as seguintes informações: os fluxos de pedestres sugeridos como fronteiras para os níveis de serviço propostos pelo HCM (2000); os níveis de serviço correspondentes aos fluxos da coluna anterior; os fluxos de pedestres adaptados ao modelo proposto nesta pesquisa; a largura efetiva considerada; o número total de ciclistas na via (equivalente a zero) e a insatisfação dos pedestres definida pelo modelo proposto.

Tabela 7.3 - Insatisfação dos pedestres para largura efetiva de calçadas de $1 \mathrm{~m}$.

\begin{tabular}{cccccc}
\hline $\begin{array}{c}\text { Ped/m/min } \\
\text { HCM (2000) }\end{array}$ & $\begin{array}{c}\text { Nível de Serviço } \\
\text { HCM (2000) }\end{array}$ & $\begin{array}{c}\text { Ped/5min/m } \\
\text { Modelo }\end{array}$ & $\begin{array}{c}\text { Lef } \\
(\mathrm{m})\end{array}$ & $\begin{array}{c}\text { Cicltot } \\
\text { Insatisfação } \\
(\%)\end{array}$ \\
\hline 16 & A & 80 & 1 & 0 & 27 \\
\hline 23 & B & 115 & 1 & 0 & 35 \\
\hline 33 & C & 165 & 1 & 0 & 43 \\
\hline 49 & D & 245 & 1 & 0 & 52 \\
\hline 75 & E & 375 & 1 & 0 & 62 \\
\hline
\end{tabular}

Tabela 7.4 - Insatisfação dos pedestres para largura efetiva de calçadas de $2 \mathrm{~m}$.

\begin{tabular}{cccccc}
\hline $\begin{array}{c}\text { Ped/m/min } \\
\text { HCM (2000) }\end{array}$ & $\begin{array}{c}\text { Nível de Serviço } \\
\text { HCM (2000) }\end{array}$ & $\begin{array}{c}\text { Ped/5min/m } \\
\text { Modelo }\end{array}$ & $\begin{array}{c}\text { Lef } \\
(\mathrm{m})\end{array}$ & $\begin{array}{c}\text { Cicltot } \\
\text { Insatisfação } \\
(\%)\end{array}$ \\
\hline 16 & A & 160 & 2 & 0 & 36 \\
\hline 23 & B & 230 & 2 & 0 & 44 \\
\hline 33 & C & 330 & 2 & 0 & 53 \\
\hline 49 & D & 490 & 2 & 0 & 62 \\
\hline 75 & E & 750 & 2 & 0 & 73 \\
\hline
\end{tabular}


Tabela 7.5 - Insatisfação dos pedestres para largura efetiva de calçadas de $3 \mathrm{~m}$.

\begin{tabular}{|c|c|c|c|c|c|}
\hline $\begin{array}{l}\mathrm{Ped} / \mathrm{m} / \mathrm{min} \\
\mathrm{HCM}(2000)\end{array}$ & $\begin{array}{l}\text { Nível de Serviço } \\
\text { HCM (2000) }\end{array}$ & $\begin{array}{l}\mathrm{Ped} / 5 \mathrm{~min} / \mathrm{m} \\
\text { Modelo }\end{array}$ & $\begin{array}{l}\text { Lef } \\
(\mathrm{m})\end{array}$ & Cicltot & $\begin{array}{c}\text { Insatisfação } \\
(\%)\end{array}$ \\
\hline 16 & A & 240 & 3 & 0 & 35 \\
\hline 23 & B & 345 & 3 & 0 & 44 \\
\hline 33 & C & 495 & 3 & 0 & 53 \\
\hline 49 & D & 735 & 3 & 0 & 63 \\
\hline 75 & $E$ & 1125 & 3 & 0 & 74 \\
\hline
\end{tabular}

Tabela 7.6 - Insatisfação dos pedestres para largura efetiva de calçadas de $4 \mathrm{~m}$.

\begin{tabular}{|c|c|c|c|c|c|}
\hline $\begin{array}{l}\mathrm{Ped} / \mathrm{min} / \mathrm{m} \\
\mathrm{HCM}(2000)\end{array}$ & $\begin{array}{c}\text { Nível de Serviço } \\
\text { HCM (2000) }\end{array}$ & $\begin{array}{l}\mathrm{Ped} / 5 \mathrm{~min} / \mathrm{m} \\
\text { Modelo }\end{array}$ & $\begin{array}{l}\text { Lef } \\
(\mathrm{m})\end{array}$ & Cicltot & $\begin{array}{c}\text { Insatisfação } \\
(\%)\end{array}$ \\
\hline 16 & $\bar{A}$ & 320 & 4 & 0 & 28 \\
\hline 23 & $B$ & 460 & 4 & 0 & 37 \\
\hline 33 & C & 660 & 4 & 0 & 46 \\
\hline 49 & $\mathrm{D}$ & 980 & 4 & 0 & 56 \\
\hline 75 & $E$ & 1500 & 4 & 0 & 68 \\
\hline
\end{tabular}

Pode-se perceber que os valores da insatisfação dos pedestres, encontrados pelo modelo proposto, para um mesmo nível de serviço, segundo o HCM (2000), são diferentes quando há variação no fluxo de pedestres e na largura efetiva de calçada. A fim de se obter um valor para a insatisfação dos pedestres, considerando o efeito de diferentes larguras efetivas, foi calculado um valor médio para tal parâmetro, correspondente a cada um dos respectivos níveis de serviço em questão.

A insatisfação média dos pedestres, obtida pelo modelo proposto, e a equivalência dos seus valores com os respectivos níveis de serviço sugeridos pelo HCM (2000), podem ser observados na tabela abaixo. 
Tabela 7.7 - Valores médios da insatisfação dos pedestres para largura efetiva de 1,2,3 e 4m X Níveis de Serviço HCM (2000).

\begin{tabular}{ccc}
\hline $\begin{array}{c}\text { Fluxo de pedestres } \\
(\text { Ped/5min/m })\end{array}$ & $\begin{array}{c}\text { Insatisfação Média } \\
(\%)\end{array}$ & $\begin{array}{c}\text { Nível de Serviço } \\
\text { HCM }(2000)\end{array}$ \\
\hline 80 & 32 & $\mathrm{~A}$ \\
\hline 115 & 40 & $\mathrm{~B}$ \\
\hline 165 & 49 & $\mathrm{C}$ \\
\hline 245 & 58 & $\mathrm{D}$ \\
\hline 375 & 69 & $\mathrm{E}$ \\
\hline Fluxo congestionado & $\mathrm{A}$ partir de 70 & $\mathrm{~F}$ \\
\hline
\end{tabular}

A comparação entre os intervalos da insatisfação média dos pedestres, a partir do modelo proposto nesta pesquisa, com os resultados do HCM (2000), pode ser observada na tabela 7.8 .

Tabela 7.8 - Comparação entre os resultados do modelo proposto com os resultados do HCM (2000).

\begin{tabular}{cccc}
\hline $\begin{array}{c}\text { Fluxo de pedestres } \\
\text { (ped/min/m) } \\
\text { HCM }(2000)\end{array}$ & $\begin{array}{c}\text { Fluxo de pedestres } \\
\text { (ped/min/m) } \\
\text { Modelo proposto }\end{array}$ & $\begin{array}{c}\text { Nível de Serviço } \\
\text { HCM }(2000)\end{array}$ & $\begin{array}{c}\text { Insatisfação média } \\
(\%) \\
\text { Modelo proposto }\end{array}$ \\
\hline 16 & 80 & $\mathrm{~A}$ & Até 32 \\
\hline 23 & 115 & $\mathrm{~B}$ & $32-40$ \\
\hline 33 & 165 & $\mathrm{C}$ & $40-49$ \\
\hline 49 & 245 & $\mathrm{D}$ & $49-58$ \\
\hline 75 & 375 & $\mathrm{E}$ & $58-69$ \\
\hline Fluxo congestionado & Fluxo congestionado & $\mathrm{F}$ & A partir de 70 \\
\hline
\end{tabular}

Observando-se os intervalos da insatisfação dos pedestres, na tabela 7.8 , percebe-se que a equivalência do valor de $32 \%$ do modelo ao nível de serviço "A", proposto pelo HCM (2000), é um valor razoável, pois, tal relação demonstra que praticamente $70 \%$ dos pedestres estão satisfeitos realizando seus deslocamentos por uma determinada calçada.

Da mesma forma, percebe-se que o intervalo da insatisfação do modelo, equivalente ao nível de serviço "C" do HCM (2000), é razoável, pois, sendo a variação 
deste de 40 a $49 \%$, significa dizer que praticamente $50 \%$ dos pedestres estão satisfeitos ao realizarem seus deslocamentos por uma determinada calçada. Assim, verifica-se que o nível de serviço " $\mathrm{C}$ ", que é considerado aceitável para projetos, corresponde à satisfação limite dos pedestres (50\%).

A partir das observações acima, acerca das comparações apresentadas na tabela 7.8, percebe-se que há uma coerência entre os valores da insatisfação dos pedestres e os níveis de serviço propostos pelo HCM (2000), e, sendo assim, pode-se a partir deste momento, assumir que o valor da insatisfação dos pedestres, encontrado pelo modelo proposto, corresponde a um determinado nível de serviço, conforme mostrado na tabela 7.8. Por esta razão, na tabela abaixo são apresentados os parâmetros para a definição do nível de serviço de calçadas, considerando o nível de satisfação dos pedestres, de acordo com o modelo proposto nesta pesquisa.

Tabela 7.9 - Determinação do Nível de serviço das calçadas segundo a satisfação dos pedestres.

\begin{tabular}{ccc}
\hline $\begin{array}{c}\text { Fluxo de pedestres } \\
\text { (ped/5min/m) } \\
\text { Modelo proposto }\end{array}$ & $\begin{array}{c}\text { Insatisfação média } \\
\text { Modelo proposto }(\%)\end{array}$ & $\begin{array}{c}\text { Nível de Serviço } \\
\text { Modelo proposto }\end{array}$ \\
\hline 80 & Até 32 & $\mathrm{A}$ \\
\hline 115 & $32-40$ & $\mathrm{~B}$ \\
\hline 165 & $40-49$ & $\mathrm{C}$ \\
\hline 245 & $49-58$ & $\mathrm{D}$ \\
\hline 375 & $58-69$ & $\mathrm{E}$ \\
\hline Fluxo congestionado & A partir de 69 & $\mathrm{~F}$ \\
\hline
\end{tabular}

Convém destacar que o critério adotado pelo HCM (2000) para a determinação de nível de serviço foi o da capacidade. Desta forma, pode-se dizer que o modelo proposto nesta pesquisa, apesar de utilizar o critério da satisfação dos pedestres, contempla também o critério da capacidade. 


\subsection{COMPARAÇÃO DOS RESULTADOS DO MODELO PROPOSTO COM OUTROS ESTUDOS}

Nas tabelas seguintes serão realizadas comparações entre os níveis de serviço do modelo ora proposto, com outros estudos, que se valem do mesmo critério adotado pelo HCM (2000) para a definição do nível de serviço.

A tabela 7.10 apresenta uma comparação dos resultados, em termos de fluxo de pedestres e níveis de serviço, obtidos por Fruin (1971), com os resultados obtidos através do modelo proposto nesta pesquisa, utilizando como fronteiras os mesmos fluxos de pedestres propostos por Fruin (1971), porém transformados para o período de tempo de 5 minutos. As duas últimas colunas da referida tabela mostram, da esquerda para direita, respectivamente, os valores da faixa de insatisfação dos pedestres a partir dos fluxos transformados e as fronteiras de insatisfação do modelo proposto.

Tabela 7.10 - Comparação dos resultados encontrados pelo modelo proposto e pelo estudo de Fruin (1971).

\begin{tabular}{cccc}
\hline $\begin{array}{c}\text { Fruin (1971) } \\
\text { Ped/min/m }\end{array}$ & $\begin{array}{c}\text { Modelo } \\
\text { Ped/5min/m }\end{array}$ & $\begin{array}{c}\text { Faixa de } \\
\text { Insatisfação } \\
(\%)\end{array}$ & $\begin{array}{c}\text { Limites de } \\
\text { insatisfação } \\
\text { do modelo }\end{array}$ \\
\hline 23 & 116 & $0-35$ & $0-32$ \\
\hline 33 & 165 & $35-43$ & $32-40$ \\
\hline 50 & 248 & $43-52$ & $40-49$ \\
\hline 66 & 330 & $52-59$ & $49-58$ \\
\hline 83 & 413 & $59-64$ & $58-69$ \\
\hline $\begin{array}{c}\text { Fluxo } \\
\text { congestionado }\end{array}$ & $\begin{array}{c}\text { Fluxo } \\
\text { congestionado }\end{array}$ & $>64$ & $>69$ \\
\hline
\end{tabular}

Observa-se pela tabela 7.10 que os valores das faixas de insatisfação, obtidas através dos fluxos transformados, divergem, em média, 3\% das fronteiras limites de 
insatisfação do modelo proposto. Para os valores correspondentes aos níveis de serviço $A, B$ e $C$, o valor da divergência foi também de $3 \%$. A maior divergência está compreendida na faixa de insatisfação correspondente ao nível de serviço $E$, com valor de $5 \%$.

A tabela 7.11 apresenta uma comparação dos resultados, em termos de fluxo de pedestres e níveis de serviço, obtidos pela CBTU (1979), com os resultados obtidos usando o modelo proposto nesta pesquisa, caso fossem utilizados como fronteiras, os mesmos fluxos de pedestres, propostos pelo estudo em questão, porém transformados para o período de tempo de 5 minutos. As duas últimas colunas da referida tabela mostram, da esquerda para direita, respectivamente, os valores da faixa de insatisfação dos pedestres a partir dos fluxos transformados e as fronteiras de insatisfação do modelo proposto.

Tabela 7.11 - Comparação dos resultados encontrados pelo modelo proposto e pelo estudo da CBTU (1979).

\begin{tabular}{cccc}
\hline $\begin{array}{c}\text { CBTU (1979) } \\
\text { Ped/min/m }\end{array}$ & $\begin{array}{c}\text { Modelo } \\
\text { Ped/5min/m }\end{array}$ & $\begin{array}{c}\text { Faixa de } \\
\text { Insatisfação } \\
(\%)\end{array}$ & $\begin{array}{c}\text { Limites de } \\
\text { insatisfação } \\
\text { do modelo }\end{array}$ \\
\hline 21 & 105 & $0-33$ & $0-32$ \\
\hline 30 & 150 & $33-41$ & $32-40$ \\
\hline 45 & 225 & $41-50$ & $40-49$ \\
\hline 60 & 300 & $50-56$ & $49-58$ \\
\hline 75 & 375 & $56-62$ & $58-69$ \\
\hline $\begin{array}{c}\text { Fluxo } \\
\text { congestionado }\end{array}$ & $\begin{array}{c}\text { Fluxo } \\
\text { congestionado }\end{array}$ & $>62$ & $>69$ \\
\hline
\end{tabular}

Observa-se pela tabela 7.11 que os valores das faixas de insatisfação, obtidas através dos fluxos transformados, divergem, em média, 2\% das fronteiras limites de insatisfação do modelo proposto. Para os valores correspondentes aos níveis de serviço $A, B$ e $C$, o valor da divergência é de $1 \%$. A maior divergência está compreendida na faixa de insatisfação correspondente ao nível de serviço $E$, com valor de $7 \%$. 
A tabela 7.12 apresenta uma comparação dos resultados, em termos de fluxo de pedestres e níveis de serviço, obtidos pela EBTU (1984), com os resultados obtidos usando o modelo proposto nesta pesquisa, caso fossem utilizados como fronteiras, os mesmos fluxos de pedestres, propostos pelo estudo em questão, porém transformados para o período de tempo de 5 minutos. As duas últimas colunas da referida tabela mostram, da esquerda para direita, respectivamente, os valores da faixa de insatisfação dos pedestres a partir dos fluxos transformados e as fronteiras de insatisfação do modelo proposto.

Tabela 7.12 - Comparação dos resultados encontrados pelo modelo proposto e pelo estudo da EBTU (1984).

\begin{tabular}{cccc}
\hline $\begin{array}{c}\text { EBTU (1984) } \\
\text { Ped/min/m }\end{array}$ & $\begin{array}{c}\text { Modelo } \\
\text { Ped/5min/m }\end{array}$ & $\begin{array}{c}\text { Faixa de } \\
\text { Insatisfação } \\
(\%)\end{array}$ & $\begin{array}{c}\text { Limites de } \\
\text { insatisfação } \\
\text { do modelo }\end{array}$ \\
\hline 20 & 100 & $0-32$ & $0-32$ \\
\hline 33 & 165 & $32-43$ & $32-40$ \\
\hline 46 & 230 & $43-50$ & $40-49$ \\
\hline 59 & 295 & $50-56$ & $49-58$ \\
\hline 83 & 415 & $56-64$ & $58-69$ \\
\hline $\begin{array}{c}\text { Fluxo } \\
\text { congestionado }\end{array}$ & $\begin{array}{c}\text { Fluxo } \\
\text { congestionado }\end{array}$ & $>64$ & $>69$ \\
\hline
\end{tabular}

Observa-se pela tabela 7.12 que os valores das faixas de insatisfação, obtidas através dos fluxos transformados, divergem, em média, $2 \%$ das fronteiras limites de insatisfação do modelo proposto. Para os valores correspondentes aos níveis de serviço $A, B$ e $C$, os valores da divergência foram, respectivamente, $0 \%, 3 \%$ e $1 \%$. $A$ maior divergência está compreendida na faixa de insatisfação correspondente ao nível de serviço $\mathrm{E}$, com valor de $5 \%$.

Observando os resultados das comparações realizadas, percebe-se que, há uma pequena diferença entre os níveis de serviço propostos por cada um dos estudos em questão e o modelo proposto nesta pesquisa. Tal fato, pode ser explicado 
exatamente pela maneira diferenciada, com que foram obtidos os limites para os fluxos médios, definidos em cada estudo, particularmente.

Os referidos limites foram obtidos a partir da variação de dois parâmetros: área de ocupação do pedestre e a sua velocidade. Os estudos baseados no critério da capacidade assumem que, quanto menor for o espaço destinado à circulação dos pedestres, maior será a redução da velocidade de caminhada imposta a estes, e conseqüentemente, haverá uma redução no nível de serviço dos seus deslocamentos.

Desta maneira, foram definidos dois limites para os valores da velocidade dos pedestres: um superior, onde os pedestres poderiam desenvolver qualquer velocidade de caminhada; e outro inferior, onde a caminhada seria forçada, muito lenta, semelhantemente a um fluxo congestionado. O limite superior corresponde a um nível de serviço $A$, de forma oposta, o limite inferior corresponde a um nível de serviço $F$. Assim, a partir de reduções gradativas dos espaços destinados à circulação dos pedestres, foram também definidos níveis diferentes de serviço.

Sabe-se que, a partir dos referidos estudos, o fluxo de pedestres pode ser obtido pela equação abaixo:

$$
F_{p e d}=V_{p e d} x D_{p e d}
$$

$\mathrm{F}_{\text {ped }} \rightarrow$ fluxo de pedestres (pedestres/minuto/metro)

$\mathrm{V}_{\text {ped }} \rightarrow$ Velocidade dos pedestres (metro/minuto)

$D_{\text {ped }} \rightarrow$ Densidade dos pedestres (pedestre $/ \mathrm{m}^{2}$ )

Portanto, os fluxos de pedestres, definidos como fronteiras para os níveis de serviço propostos por estudos passados, dependem dos valores adotados para a área de ocupação dos pedestres na calçada, que é igual ao inverso da densidade dos pedestres. Entretanto, essas áreas nem sempre tiveram o mesmo valor. 
A EBTU (1984) afirma que, os critérios para a diferenciação entre os vários níveis de serviço para o fluxo de pedestres são necessariamente imprecisos e as especificações dos pontos demarcados são algo subjetivas. Contudo, é possível sugerir faixas apropriadas do espaço por pedestre e das taxas de fluxo, que podem ser utilizadas para desenvolver a qualidade dos critérios de fluxo.

As tabelas seguintes mostram as diferentes demarcações de espaços, bem como os diferentes fluxos limites de pedestres, de alguns estudos que utilizam o critério da capacidade para a diferenciação dos seus níveis de serviço.

Tabela 7.13 - Estudo realizado pelo HCM (2000).

\begin{tabular}{cccc}
\hline Nível de Serviço & $\mathrm{M}^{2} /$ Pedestre & Pedestre/ $\mathrm{M}^{2}$ & Pedestre/Min./M \\
\hline A & 5,6 ou mais & 0,2 ou menos & 16 ou menos \\
\hline B & 3,7 a 5,6 & 0,3 a 0,2 & 23 \\
\hline C & 2,2 a 3,7 & 0,4 a 0,3 & 33 \\
\hline D & 1,4 a 2,2 & 0,7 a 0,4 & 49 \\
\hline E & 0,75 a 1,4 & 1,33 a 0,7 & 75 \\
\hline F & 0,75 ou menos & 1,33 ou mais & Fluxo congestionado \\
\hline
\end{tabular}

Tabela 7.14 - Estudo realizado por Fruin (1971).

\begin{tabular}{cccc}
\hline Nível de Serviço & M $^{2} /$ Pedestre & Pedestre/ $\mathrm{M}^{2}$ & Pedestre/Min./M \\
\hline A & 3,25 ou mais & 0,31 ou menos & 23 ou menos \\
\hline B & 2,32 a 3,25 & 0,43 a 0,31 & 33 \\
\hline C & 1,39 a 2,32 & 0,72 a 0,43 & 50 \\
\hline D & 0,93 a 1,39 & 1,08 a 0,72 & 66 \\
\hline E & 0,46 a 0,93 & 2,17 a 1,08 & 83 \\
\hline F & 0,460 ou menos & 2,17 ou mais & Fluxo congestionado \\
\hline
\end{tabular}

Tabela 7.15 - Estudo realizado pela CBTU (1979).

\begin{tabular}{cccc}
\hline Nível de Serviço & $\mathrm{M}^{2} /$ Pedestre & Pedestre/ $\mathrm{M}^{2}$ & Pedestre/M/Min. \\
\hline $\mathrm{A}$ & 3,2 ou mais & 0,3 ou menos & 21 ou menos \\
\hline $\mathrm{B}$ & 2,3 a 3,2 & 0,3 a 0,4 & 30 \\
\hline $\mathrm{C}$ & 1,4 a 2,3 & 0,4 a 0,7 & 45 \\
\hline $\mathrm{D}$ & 0,9 a 1,4 & 0,7 a 1,0 & 60 \\
\hline $\mathrm{E}$ & 0,5 a 0,9 & 1,0 a 2,0 & 75 \\
\hline $\mathrm{F}$ & 0,5 ou menos & 2,0 ou mais & 75,0 ou mais \\
\hline
\end{tabular}


Tabela 7.16 - Estudo realizado pela EBTU (1984).

\begin{tabular}{cccc}
\hline Nível de Serviço & $\mathrm{M}^{2} /$ Pedestre & Pedestre/ $\mathrm{M}^{2}$ & Pedestre/M/Min. \\
\hline $\mathrm{A}$ & 3,72 ou mais & 0,27 ou menos & 20 ou menos \\
\hline $\mathrm{B}$ & 2,23 a 3,72 & 0,27 a 0,45 & 33 \\
\hline $\mathrm{C}$ & 1,48 a 2,23 & 0,45 a 0,68 & 46 \\
\hline $\mathrm{D}$ & 1,02 a 1,48 & 0,68 a 0,98 & 59 \\
\hline $\mathrm{E}$ & 0,56 a 1,02 & 0,98 a 1,79 & 83 \\
\hline $\mathrm{F}$ & 0,5 ou menos & 2,0 ou mais & 83 ou mais \\
\hline
\end{tabular}

Pode-se perceber que, a definição da área de ocupação média por pedestres $\left(\mathrm{m}^{2} /\right.$ ped), proposta por cada estudo, acarreta em taxas de fluxos de pedestres ( $\mathrm{ped} / \mathrm{min} / \mathrm{m})$ diferenciadas, e conseqüentemente, em níveis de serviço diferentes. Portanto cabe aqui avaliar não a semelhança dos resultados, do modelo proposto nesta pesquisa, com os demais resultados, e sim, a coerência existente entre os mesmos.

Tal conformidade pode ser observada, pela comparação dos níveis de serviço C, que é uma situação limite para projetos, propostos por cada um dos estudos com os resultados do modelo proposto nesta pesquisa. A insatisfação média, obtida pelo modelo proposto, para o nível de serviço "C"oscila de $41 \%$ a $49 \%$, ficando portanto, próximo ao valor de $50 \%$, que corresponde à insatisfação admissível para os pedestres.

Dentre as comparações feitas nesta pesquisa, apenas no estudo de Fruin (1971) o modelo proposto apresentou para o nível de serviço C o valor de $52 \%$, que não diverge muito da condição limite (50 \%). Entretanto, para os níveis de serviço A, B e C as divergências mostraram-se pouco relevantes, principalmente, considerando-se o fato de que os valores de insatisfação são dados em porcentagem. Com isso, podese afirmar que o modelo desta pesquisa é satisfatório para definir níveis de serviço para calçadas, considerando o nível de satisfação dos pedestres. 
A tabela 7.17 abaixo, apresenta uma comparação entre os valores limites para níveis de serviço, obtidos pelo modelo proposto nesta pesquisa, e os sugeridos pelo estudo realizado por Khisty (1994).

Tabela 7.17 - Comparação dos resultados encontrados pelo modelo proposto e pelo estudo de Khisty (1995).

\begin{tabular}{ccc}
\hline $\begin{array}{c}\text { Satisfação (\%) } \\
\text { Khisty (1994) }\end{array}$ & $\begin{array}{c}\text { Insatisfação (\%) } \\
\text { Modelo proposto }\end{array}$ & $\begin{array}{c}\text { Satisfação ( \% ) } \\
\text { Modelo proposto }\end{array}$ \\
\hline$>85$ & $0-32$ & $>68$ \\
\hline $60-85$ & $32-40$ & $60-68$ \\
\hline $45-60$ & $40-49$ & $51-60$ \\
\hline $30-45$ & $49-58$ & $42-51$ \\
\hline $15-30$ & $58-69$ & $31-42$ \\
\hline$<15$ & $>69$ & $<31$ \\
\hline
\end{tabular}

Nota-se, pela tabela 7.17, que os limites propostos por Khisty (1994) não coincidem com os limites estabelecidos pelo modelo obtido nesta pesquisa. Convém destacar, que ambos os modelos utilizaram o critério de satisfação dos pedestres, entretanto, para avaliar atributos diferentes. O estudo de Khisty (1994) procurou medir a qualidade de deslocamento dos pedestres em relação às condições de conforto e segurança dos pedestres, da manutenção das calçadas, e do ambiente em questão, ou seja, em momento algum houve a preocupação de verificar a impedância causada aos deslocamentos dos pedestres, causada em função dos aspectos operacionais das vias, como por exemplo, a presença do fluxo de ciclistas.

\subsection{FRONTEIRAS PARA OS NÍVEIS DE SERVIÇO DEFINIDOS PELO MODELO PROPOSTO CONSIDERANDO OS CICLISTAS DA VIA}

No item anterior foi comprovada a consistência do modelo proposto nesta pesquisa, a partir das comparações dos resultados deste com os de outros estudos 
encontrados na bibliografia. Convém ressaltar que, para se chegar a tal comprovação, considerou-se a variável correspondente ao número total de ciclistas na via, pertencente ao modelo, equivalente a 0 (zero), pois, nos demais estudos não há nenhuma menção sobre a influência dos ciclistas no nível de serviço dos pedestres.

Entretanto, verificou-se nesta pesquisa a influência que o número de ciclistas, em trânsito por uma via, tem sobre a satisfação dos pedestres nas calçadas, reduzindo assim o nível de serviço destes últimos. Por este motivo, e com a intenção de tornar o modelo aplicável à realidade da cidade de Boa Vista, foram definidos para cada nível de serviço limites para os fluxos de pedestres, considerando diferentes larguras efetivas de calçadas e diferentes fluxos de ciclistas nas vias, porém, em conformidade com os da coleta de campo.

Os valores dos parâmetros citados acima podem ser observados nas tabelas a seguir, que foram geradas a partir de simulações feitas utilizando o modelo I.

Tabela 7.18 - Fluxos de pedestres limites para calçadas com $1 \mathrm{~m}$ de largura efetiva, considerando 10 ciclistas em trânsito na via.

\begin{tabular}{cccccc}
\hline $\begin{array}{c}\text { Limite } \\
\text { superior } \\
\text { ped/5min/m) }\end{array}$ & $\begin{array}{c}\text { Fluxo } \\
\text { (ped/min/m) }\end{array}$ & $\begin{array}{c}\text { Largura } \\
\text { Efetiva }(\mathrm{m})\end{array}$ & $\begin{array}{c}\text { Fluxo total de } \\
\text { Ciclistas na } \\
\text { via }\end{array}$ & $\begin{array}{c}\text { Insatisfação } \\
(\%)\end{array}$ & $\begin{array}{c}\text { Nível de } \\
\text { Serviço }\end{array}$ \\
\hline 1,9 & 0,4 & 1 & 10 & 32 & $\mathrm{~A}$ \\
\hline 3,3 & 0,7 & 1 & 10 & 40 & $\mathrm{~B}$ \\
\hline 5,8 & 1,2 & 1 & 10 & 49 & $\mathrm{C}$ \\
\hline 10,5 & 2,1 & 1 & 10 & 58 & $\mathrm{D}$ \\
\hline 19,7 & 3,9 & 1 & 10 & 69 & $\mathrm{E}$ \\
\hline
\end{tabular}

Tabela 7.19 - Fluxos de pedestres limites para calçadas com $2 \mathrm{~m}$ de largura efetiva, considerando 10 ciclistas em trânsito na via.

\begin{tabular}{cccccc}
\hline $\begin{array}{c}\text { Limite } \\
\text { superior } \\
\text { (ped/5min/m) }\end{array}$ & $\begin{array}{c}\text { Fluxo } \\
(\text { ped } / \mathrm{min} / \mathrm{m})\end{array}$ & $\begin{array}{c}\text { Largura } \\
\text { Efetiva }(\mathrm{m})\end{array}$ & $\begin{array}{c}\text { Fluxo total de } \\
\text { Ciclistas na } \\
\text { via }\end{array}$ & $\begin{array}{c}\text { Insatisfação } \\
(\%)\end{array}$ & $\begin{array}{c}\text { Nível de } \\
\text { Serviço }\end{array}$ \\
\hline 2,9 & 0,6 & 2 & 10 & 32 & $\mathrm{~A}$ \\
\hline 4,9 & 1,0 & 2 & 10 & 40 & $\mathrm{~B}$ \\
\hline 8,4 & 1,7 & 2 & 10 & 49 & $\mathrm{C}$ \\
\hline 14,8 & 3,0 & 2 & 10 & 58 & $\mathrm{D}$ \\
\hline 27,2 & 5,4 & 2 & 10 & 69 & $\mathrm{E}$ \\
\hline
\end{tabular}


Tabela 7.20 - Fluxos de pedestres limites para calçadas com $3 \mathrm{~m}$ de largura efetiva, considerando 10 ciclistas em trânsito na via.

\begin{tabular}{cccccc}
\hline $\begin{array}{c}\text { Limite } \\
\text { superior } \\
\text { ped/5min } / \mathrm{m})\end{array}$ & $\begin{array}{c}\text { Fluxo } \\
\text { (ped/min/m) }\end{array}$ & $\begin{array}{c}\text { Largura } \\
\text { Efetiva }(\mathrm{m})\end{array}$ & $\begin{array}{c}\text { Fluxo total de } \\
\text { Ciclistas na } \\
\text { via }\end{array}$ & $\begin{array}{c}\text { Insatisfação } \\
(\%)\end{array}$ & $\begin{array}{c}\text { Nível de } \\
\text { Serviço }\end{array}$ \\
\hline 5,4 & 1,1 & 3 & 10 & 32 & $\mathrm{~A}$ \\
\hline 9,1 & 1,8 & 3 & 10 & 40 & $\mathrm{~B}$ \\
\hline 15,0 & 3,0 & 3 & 10 & 49 & $\mathrm{C}$ \\
\hline 25,7 & 5,1 & 3 & 10 & 58 & $\mathrm{D}$ \\
\hline 45,6 & 9,1 & 3 & 10 & 69 & $\mathrm{E}$ \\
\hline
\end{tabular}

Tabela 7.21 - Fluxos de pedestres limites para calçadas com $4 \mathrm{~m}$ de largura efetiva, considerando 10 ciclistas em trânsito na via.

\begin{tabular}{cccccc}
\hline $\begin{array}{c}\text { Limite } \\
\text { superior } \\
\text { (ped/5min/m) }\end{array}$ & $\begin{array}{c}\text { Fluxo } \\
(\text { ped/min/m) }\end{array}$ & $\begin{array}{c}\text { Largura } \\
\text { Efetiva }(\mathrm{m})\end{array}$ & $\begin{array}{c}\text { Fluxo total de } \\
\text { Ciclistas na } \\
\text { via }\end{array}$ & $\begin{array}{c}\text { Insatisfação } \\
(\%)\end{array}$ & $\begin{array}{c}\text { Nível de } \\
\text { Serviço }\end{array}$ \\
\hline 12,6 & 2,5 & 4 & 10 & 32 & $\mathrm{~A}$ \\
\hline 20,2 & 4,0 & 4 & 10 & 40 & $\mathrm{~B}$ \\
\hline 32,0 & 6,4 & 4 & 10 & 49 & $\mathrm{C}$ \\
\hline 52,9 & 10,6 & 4 & 10 & 58 & $\mathrm{D}$ \\
\hline 90,4 & 18,1 & 4 & 10 & 69 & $\mathrm{E}$ \\
\hline
\end{tabular}

Tabela 7.22 - Fluxos de pedestres limites para calçadas com $1 \mathrm{~m}$ de largura efetiva, considerando 20 ciclistas em trânsito na via.

\begin{tabular}{cccccc}
\hline $\begin{array}{c}\text { Limite } \\
\text { superior } \\
\text { ped/5min/m) }\end{array}$ & $\begin{array}{c}\text { Fluxo } \\
(\text { ped/min/m) }\end{array}$ & $\begin{array}{c}\text { Largura } \\
\text { Efetiva }(\mathrm{m})\end{array}$ & $\begin{array}{c}\text { Fluxo total de } \\
\text { Ciclistas na } \\
\text { via }\end{array}$ & $\begin{array}{c}\text { Insatisfação } \\
(\%)\end{array}$ & $\begin{array}{c}\text { Nível de } \\
\text { Serviço }\end{array}$ \\
\hline 1,3 & 0,3 & 1 & 20 & 32 & $\mathrm{~A}$ \\
\hline 2,4 & 0,5 & 1 & 20 & 40 & $\mathrm{~B}$ \\
\hline 4,2 & 0,8 & 1 & 20 & 49 & $\mathrm{C}$ \\
\hline 7,8 & 1,6 & 1 & 20 & 58 & $\mathrm{D}$ \\
\hline 14,9 & 3,0 & 1 & 20 & 69 & $\mathrm{E}$ \\
\hline
\end{tabular}

Tabela 7.23 - Fluxos de pedestres limites para calçadas com $2 \mathrm{~m}$ de largura efetiva, considerando 20 ciclistas em trânsito na via.

\begin{tabular}{cccccc}
\hline $\begin{array}{c}\text { Limite } \\
\text { superior } \\
\text { (ped/5min/m) }\end{array}$ & $\begin{array}{c}\text { Fluxo } \\
\text { (ped/min/m) }\end{array}$ & $\begin{array}{c}\text { Largura } \\
\text { Efetiva }(\mathrm{m})\end{array}$ & $\begin{array}{c}\text { Fluxo total de } \\
\text { Ciclistas na } \\
\text { via }\end{array}$ & $\begin{array}{c}\text { Insatisfação } \\
(\%)\end{array}$ & $\begin{array}{c}\text { Nível de } \\
\text { Serviço }\end{array}$ \\
\hline 2,0 & 0,4 & 2 & 20 & 32 & $\mathrm{~A}$ \\
\hline 3,6 & 0,7 & 2 & 20 & 40 & $\mathrm{~B}$ \\
\hline 6,2 & 1,2 & 2 & 20 & 49 & $\mathrm{C}$ \\
\hline 11,1 & 2,2 & 2 & 20 & 58 & $\mathrm{D}$ \\
\hline 20,7 & 4,1 & 2 & 20 & 69 & $\mathrm{E}$ \\
\hline
\end{tabular}


Tabela 7.24 - Fluxos de pedestres limites para calçadas com $3 \mathrm{~m}$ de largura efetiva, considerando 20 ciclistas em trânsito na via.

\begin{tabular}{cccccc}
\hline $\begin{array}{c}\text { Limite } \\
\text { superior } \\
\text { (ped/5min/m) }\end{array}$ & $\begin{array}{c}\text { Fluxo } \\
(\text { ped/min/m) }\end{array}$ & $\begin{array}{c}\text { Largura } \\
\text { Efetiva }(\mathrm{m})\end{array}$ & $\begin{array}{c}\text { Fluxo total de } \\
\text { Ciclistas na } \\
\text { via }\end{array}$ & $\begin{array}{c}\text { Insatisfação } \\
(\%)\end{array}$ & $\begin{array}{c}\text { Nível de } \\
\text { Serviço }\end{array}$ \\
\hline 4,0 & 0,8 & 3 & 20 & 32 & $\mathrm{~A}$ \\
\hline 6,7 & 1,3 & 3 & 20 & 40 & $\mathrm{~B}$ \\
\hline 11,2 & 2,2 & 3 & 20 & 49 & $\mathrm{C}$ \\
\hline 19,6 & 3,9 & 3 & 20 & 58 & $\mathrm{D}$ \\
\hline 35,3 & 7,1 & 3 & 20 & 69 & $\mathrm{E}$ \\
\hline
\end{tabular}

Tabela 7.25 - Fluxos de pedestres limites para calçadas com $4 \mathrm{~m}$ de largura efetiva, considerando 20 ciclistas em trânsito na via.

\begin{tabular}{cccccc}
\hline $\begin{array}{c}\text { Limite } \\
\text { superior } \\
\text { (ped/5min } / \mathrm{m})\end{array}$ & $\begin{array}{c}\text { Fluxo } \\
\text { (ped/min/m) }\end{array}$ & $\begin{array}{c}\text { Largura } \\
\text { Efetiva }(\mathrm{m})\end{array}$ & $\begin{array}{c}\text { Fluxo total de } \\
\text { Ciclistas na } \\
\text { via }\end{array}$ & $\begin{array}{c}\text { Insatisfação } \\
(\%)\end{array}$ & $\begin{array}{c}\text { Nível de } \\
\text { Serviço }\end{array}$ \\
\hline 9,4 & 1,9 & 4 & 20 & 32 & $\mathrm{~A}$ \\
\hline 15,2 & 3,0 & 4 & 20 & 40 & $\mathrm{~B}$ \\
\hline 24,6 & 4,9 & 4 & 20 & 49 & $\mathrm{C}$ \\
\hline 41,1 & 8,2 & 4 & 20 & 58 & $\mathrm{D}$ \\
\hline 71,1 & 14,2 & 4 & 20 & 69 & $\mathrm{E}$ \\
\hline
\end{tabular}

Tabela 7.26 - Fluxos de pedestres limites para calçadas com $1 \mathrm{~m}$ de largura efetiva, considerando 30 ciclistas em trânsito na via.

\begin{tabular}{cccccc}
\hline $\begin{array}{c}\text { Limite } \\
\text { superior } \\
\text { (ped/5min/m) }\end{array}$ & $\begin{array}{c}\text { Fluxo } \\
(\text { ped/min/m) }\end{array}$ & $\begin{array}{c}\text { Largura } \\
\text { Efetiva }(\mathrm{m})\end{array}$ & $\begin{array}{c}\text { Fluxo total de } \\
\text { Ciclistas na } \\
\text { via }\end{array}$ & $\begin{array}{c}\text { Insatisfação } \\
(\%)\end{array}$ & $\begin{array}{c}\text { Nível de } \\
\text { Serviço }\end{array}$ \\
\hline 1,1 & 0,2 & 1 & 30 & 32 & $\mathrm{~A}$ \\
\hline 1,9 & 0,4 & 1 & 30 & 40 & $\mathrm{~B}$ \\
\hline 3,5 & 0,7 & 1 & 30 & 49 & $\mathrm{C}$ \\
\hline 6,5 & 1,3 & 1 & 30 & 58 & $\mathrm{D}$ \\
\hline 12,4 & 2,5 & 1 & 30 & 69 & $\mathrm{E}$ \\
\hline
\end{tabular}

Tabela 7.27 - Fluxos de pedestres limites para calçadas com $2 \mathrm{~m}$ de largura efetiva, considerando 30 ciclistas em trânsito na via.

\begin{tabular}{cccccc}
\hline $\begin{array}{c}\text { Limite } \\
\text { superior } \\
\text { (ped/5min } / \mathrm{m})\end{array}$ & $\begin{array}{c}\text { Fluxo } \\
\text { (ped/min/m) }\end{array}$ & $\begin{array}{c}\text { Largura } \\
\text { Efetiva }(\mathrm{m})\end{array}$ & $\begin{array}{c}\text { Fluxo total de } \\
\text { Ciclistas na } \\
\text { via }\end{array}$ & $\begin{array}{c}\text { Insatisfação } \\
(\%)\end{array}$ & $\begin{array}{c}\text { Nível de } \\
\text { Serviço }\end{array}$ \\
\hline 1,6 & 0,3 & 2 & 30 & 32 & $\mathrm{~A}$ \\
\hline 2,9 & 0,6 & 2 & 30 & 40 & $\mathrm{~B}$ \\
\hline 5,1 & 1,0 & 2 & 30 & 49 & $\mathrm{C}$ \\
\hline 9,3 & 1,9 & 2 & 30 & 58 & $\mathrm{D}$ \\
\hline 17,5 & 3,5 & 2 & 30 & 69 & $\mathrm{E}$ \\
\hline
\end{tabular}


Tabela 7.28 - Fluxos de pedestres limites para calçadas com $3 \mathrm{~m}$ de largura efetiva, considerando 30 ciclistas em trânsito na via.

\begin{tabular}{cccccc}
\hline $\begin{array}{c}\text { Limite } \\
\text { superior } \\
\text { ped/5min } / \mathrm{m})\end{array}$ & $\begin{array}{c}\text { Fluxo } \\
\text { (ped/min/m) }\end{array}$ & $\begin{array}{c}\text { Largura } \\
\text { Efetiva }(\mathrm{m})\end{array}$ & $\begin{array}{c}\text { Fluxo total de } \\
\text { Ciclistas na } \\
\text { via }\end{array}$ & $\begin{array}{c}\text { Insatisfação } \\
(\%)\end{array}$ & $\begin{array}{c}\text { Nível de } \\
\text { Serviço }\end{array}$ \\
\hline 3,2 & 0,6 & 3 & 30 & 32 & $\mathrm{~A}$ \\
\hline 5,5 & 1,1 & 3 & 30 & 40 & $\mathrm{~B}$ \\
\hline 9,4 & 1,9 & 3 & 30 & 49 & $\mathrm{C}$ \\
\hline 16,5 & 3,3 & 3 & 30 & 58 & $\mathrm{D}$ \\
\hline 30,0 & 6,0 & 3 & 30 & 69 & $\mathrm{E}$ \\
\hline
\end{tabular}

Tabela 7.29 - Fluxos de pedestres limites para calçadas com $4 \mathrm{~m}$ de largura efetiva, considerando 30 ciclistas em trânsito na via.

\begin{tabular}{cccccc}
\hline $\begin{array}{c}\text { Limite } \\
\text { superior } \\
\text { (ped/5min/m) }\end{array}$ & $\begin{array}{c}\text { Fluxo } \\
\text { (ped/min/m) }\end{array}$ & $\begin{array}{c}\text { Largura } \\
\text { Efetiva }(\mathrm{m})\end{array}$ & $\begin{array}{c}\text { Fluxo total de } \\
\text { Ciclistas na } \\
\text { via }\end{array}$ & $\begin{array}{c}\text { Insatisfação } \\
(\%)\end{array}$ & $\begin{array}{c}\text { Nível de } \\
\text { Serviço }\end{array}$ \\
\hline 7,8 & 1,6 & 4 & 30 & 32 & $\mathrm{~A}$ \\
\hline 12,8 & 2,6 & 4 & 30 & 40 & $\mathrm{~B}$ \\
\hline 20,7 & 4,1 & 4 & 30 & 49 & $\mathrm{C}$ \\
\hline 35,0 & 7,0 & 4 & 30 & 58 & $\mathrm{D}$ \\
\hline 61,1 & 12,2 & 4 & 30 & 69 & $\mathrm{E}$ \\
\hline
\end{tabular}

Tabela 7.30 - Fluxos de pedestres limites para calçadas com $1 \mathrm{~m}$ de largura efetiva, considerando 40 ciclistas em trânsito na via.

\begin{tabular}{cccccc}
\hline $\begin{array}{c}\text { Limite } \\
\text { superior } \\
\text { ped/5min/m) }\end{array}$ & $\begin{array}{c}\text { Fluxo } \\
(\text { ped/min/m) }\end{array}$ & $\begin{array}{c}\text { Largura } \\
\text { Efetiva }(\mathrm{m})\end{array}$ & $\begin{array}{c}\text { Fluxo total de } \\
\text { Ciclistas na } \\
\text { via }\end{array}$ & $\begin{array}{c}\text { Insatisfação } \\
(\%)\end{array}$ & $\begin{array}{c}\text { Nível de } \\
\text { Serviço }\end{array}$ \\
\hline 0,9 & 0,2 & 1 & 40 & 32 & $\mathrm{~A}$ \\
\hline 1,6 & 0,3 & 1 & 40 & 40 & $\mathrm{~B}$ \\
\hline 3,0 & 0,6 & 1 & 40 & 49 & $\mathrm{C}$ \\
\hline 5,6 & 1,1 & 1 & 40 & 58 & $\mathrm{D}$ \\
\hline 10,9 & 2,2 & 1 & 40 & 69 & $\mathrm{E}$ \\
\hline
\end{tabular}

Tabela 7.31 - Fluxos de pedestres limites para calçadas com $2 \mathrm{~m}$ de largura efetiva, considerando 40 ciclistas em trânsito na via.

\begin{tabular}{cccccc}
\hline $\begin{array}{c}\text { Limite } \\
\text { superior } \\
\text { (ped/5min/m) }\end{array}$ & $\begin{array}{c}\text { Fluxo } \\
\text { (ped/min/m) }\end{array}$ & $\begin{array}{c}\text { Largura } \\
\text { Efetiva }(\mathrm{m})\end{array}$ & $\begin{array}{c}\text { Fluxo total de } \\
\text { Ciclistas na } \\
\text { via }\end{array}$ & $\begin{array}{c}\text { Insatisfação } \\
(\%)\end{array}$ & $\begin{array}{c}\text { Nível de } \\
\text { Serviço }\end{array}$ \\
\hline 1,4 & 0,3 & 2 & 40 & 32 & $\mathrm{~A}$ \\
\hline 2,5 & 0,5 & 2 & 40 & 40 & $\mathrm{~B}$ \\
\hline 4,4 & 0,9 & 2 & 40 & 49 & $\mathrm{C}$ \\
\hline 8,1 & 1,6 & 2 & 40 & 58 & $\mathrm{D}$ \\
\hline 15,4 & 3,1 & 2 & 40 & 69 & $\mathrm{E}$ \\
\hline
\end{tabular}


Tabela 7.32 - Fluxos de pedestres limites para calçadas com $3 \mathrm{~m}$ de largura efetiva, considerando 40 ciclistas em trânsito na via.

\begin{tabular}{cccccc}
\hline $\begin{array}{c}\text { Limite } \\
\text { superior } \\
\text { (ped/5min } / \mathrm{m})\end{array}$ & $\begin{array}{c}\text { Fluxo } \\
(\text { ped/min/m) }\end{array}$ & $\begin{array}{c}\text { Largura } \\
\text { Efetiva }(\mathrm{m})\end{array}$ & $\begin{array}{c}\text { Fluxo total de } \\
\text { Ciclistas na } \\
\text { via }\end{array}$ & $\begin{array}{c}\text { Insatisfação } \\
(\%)\end{array}$ & $\begin{array}{c}\text { Nível de } \\
\text { Serviço }\end{array}$ \\
\hline 2,8 & 0,6 & 3 & 40 & 32 & $\mathrm{~A}$ \\
\hline 4,8 & 1,0 & 3 & 40 & 40 & $\mathrm{~B}$ \\
\hline 8,2 & 1,6 & 3 & 40 & 49 & $\mathrm{C}$ \\
\hline 14,5 & 2,9 & 3 & 40 & 58 & $\mathrm{D}$ \\
\hline 26,6 & 5,3 & 3 & 40 & 69 & $\mathrm{E}$ \\
\hline
\end{tabular}

Tabela 7.33 - Fluxos de pedestres limites para calçadas com $4 \mathrm{~m}$ de largura efetiva, considerando 40 ciclistas em trânsito na via.

\begin{tabular}{cccccc}
\hline $\begin{array}{c}\text { Limite } \\
\text { superior } \\
\text { (ped/5min/m) }\end{array}$ & $\begin{array}{c}\text { Fluxo } \\
\text { (ped/min/m) }\end{array}$ & $\begin{array}{c}\text { Largura } \\
\text { Efetiva }(\mathrm{m})\end{array}$ & $\begin{array}{c}\text { Fluxo total de } \\
\text { Ciclistas na } \\
\text { via }\end{array}$ & $\begin{array}{c}\text { Insatisfação } \\
(\%)\end{array}$ & $\begin{array}{c}\text { Nível de } \\
\text { Serviço }\end{array}$ \\
\hline 6,8 & 1,4 & 4 & 40 & 32 & $\mathrm{~A}$ \\
\hline 11,2 & 2,2 & 4 & 40 & 40 & $\mathrm{~B}$ \\
\hline 18,3 & 3,7 & 4 & 40 & 49 & $\mathrm{C}$ \\
\hline 31,1 & 6,2 & 4 & 40 & 58 & $\mathrm{D}$ \\
\hline 54,6 & 10,9 & 4 & 40 & 69 & $\mathrm{E}$ \\
\hline
\end{tabular}

Os valores contidos nas tabelas acima (7.18 a 7.33), servem como parâmetros para a avaliação do nível de serviço em calçadas de vias urbanas, a partir da contagem do fluxo de pedestres sobre as mesmas, bem como da determinação da largura efetiva destas, considerando-se também, o número de ciclistas que transitam pela via observada.

\subsection{UTILIZAÇÃO DO MODELO PROPOSTO PARA DIMENSIONAMENTO DE CALÇADAS EM VIAS URBANAS}

Pode-se afirmar que o modelo I, proposto nesta pesquisa, pode ser perfeitamente utilizado para a avaliação do nível de serviço de uma determinada calçada. Entretanto, uma vez que o modelo I considera o nível de satisfação dos 
pedestres, verificou-se nesta pesquisa a sua aplicabilidade ao dimensionamento de calçadas, em locais onde não existam tais infra-estruturas.

Porém, como o modelo I depende do número de pedestres sobre a calçada que ainda não existe, torna-se necessário a definição de um novo modelo que possa fazer tal estimativa. Desta forma, através da regressão robusta $\mathrm{mm}$, pertencente ao programa S-Plus 6.1, obteve-se o modelo II, descrito abaixo.

\section{Modelo II}

$$
\text { Pedcal }=\underset{(12,15)}{0,7585} \text { Lef } \underset{(15,42)}{0,7297} \text { Pedtot } / m
$$

Onde:

Pedcal $\rightarrow$ número de pedestres na calçada da via em questão (ped/ $5 \mathrm{~min}$ );

Lef. $\rightarrow$ largura efetiva da calçada na via em questão $(m)$;

Pedtot $/ \mathrm{m} \rightarrow$ número total de pedestres por metro de calçada na via em questão (pedtot/ $5 \mathrm{~min} / \mathrm{m}$ ).

Observa-se que no modelo II, proposto acima, o número de pedestres na calçada, depende da largura efetiva desta, bem como do número de pedestres na via dividido por metro de calçada. Percebe-se no modelo que quanto maior for a largura efetiva e o número de pedestres na via, maior será o número de pedestres sobre a calçada.

Abaixo de cada coeficiente do modelo II é destacado o valor da estatística t, convém ressaltar que o valor "Pr" para todos os valores da estatística t, considerando um intervalo de confiança de $10 \%$, foi igual a 0 (zero), indicando que todos os 
coeficientes pertencentes ao modelo são significativos. O valor de $\mathrm{R}^{2}$ para o modelo II foi de $72 \%$.

Portanto, a partir do valor da estatística $t$, pode-se afirmar que, em ordem decrescente de poder explicativo, as variáveis mais importantes para a representação do número de pedestres sobre a calçada são as seguintes: a largura efetiva da calçada e o número de pedestres na via.

Verificada a consistência do modelo II, basta fazer a substituição dos valores, obtidos por este, no modelo I, para a determinação da largura efetiva da calçada, considerando o nível de satisfação do pedestre.

\section{Modelo I}

$$
\begin{gathered}
\text { Insatped }=-1,7592-0,2299 \text { Pico }+1,3240 \text { Pedcal }^{0,1}-0,0196 \text { Lef }^{2}+ \\
+0,5447 \text { Cicltot }^{0,1}
\end{gathered}
$$

\section{Modelo II}

Pedcal $=0,7585$ Lef $+0,7297$ Pedtot $/ m=\frac{\left(0,7585 \text { Lef }^{2}+0,7297 \text { Pedtot }\right)}{\text { Lef }}$

\section{Substituição de II em I :}

$$
\begin{gathered}
\text { Insatped }=-1,7592-0,2299 \text { Pico }+1,3240\left[\frac{\left(0,7585 \text { Lef }^{2}+0,7297 \text { Pedtot }\right)}{\text { Lef }}\right]^{0,1}-0,0196 \text { Lef }^{2}+ \\
+0,5447 \text { Cicltot }^{0,1}
\end{gathered}
$$

Como o principal objetivo deste trabalho é dimensionar a largura efetiva de calçadas, percebe-se que a partir do modelo II esta passa a ser uma tarefa simples, pois, para isso basta que sejam encontrados os valores das seguintes variáveis: a 
insatisfação dos pedestres; a variável categórica (pico=0; entre-picos=1); o número total de pedestres na via; e o número total de ciclistas na via.

A partir de contagens "in loco", podem ser definidos os números totais de pedestres e ciclistas que transitam pela via. O valor da variável categórica já é conhecido, conforme mostrado acima. Resta, portanto, a definição de um valor para a insatisfação dos pedestres. Este pode ser obtido definindo-se o nível de serviço da calçada a ser projetada, baseando-se nos limites da tabela 7.9.

Assim, substituindo-se os valores da variável categórica, de Cicltot e de Pedtot, na equação 7.5, e fixando-se um valor para a insatisfação dos pedestres, conforme a tabela 7.9 , será determinado o valor da largura efetiva da calçada, utilizando-se para esse fim, a função "atingir metas" no programa Excel 2002.

Pode-se observar que o modelo proposto nesta pesquisa pode ser aplicado não só para a simples avaliação de vias urbanas com infra-estruturas já definidas, como também para o planejamento urbano, permitindo ao gestor público dimensionar calçadas, considerando o nível de satisfação dos pedestres, a partir das características operacionais da via em questão.

Convém destacar que, o modelo proposto é de fácil utilização, pois, requer apenas o manuseio de máquinas de calcular programáveis. Entretanto, com o intuito de facilitar a aplicação do mesmo para uma avaliação expedita de campo, foram construídos os nomogramas, mostrados nas Figuras 7.1 e 7.3 .

Na Figura 7.1 é apresentado um nomograma para dimensionar calçadas em situações onde não exista o fluxo de ciclistas na via. Por este motivo, as variáveis encontradas no referido nomograma são as seguintes: número total de pedestres na via (Pedtot); insatisfação dos pedestres (Insatped), nos períodos de pico e entre picos; e a largura efetiva da calçada (Lef), com uma variação de $1 \mathrm{~m}$ a $4 \mathrm{~m}$. Convém destacar, que o nomograma confeccionado para um intervalo de contagem de 5 minutos. 


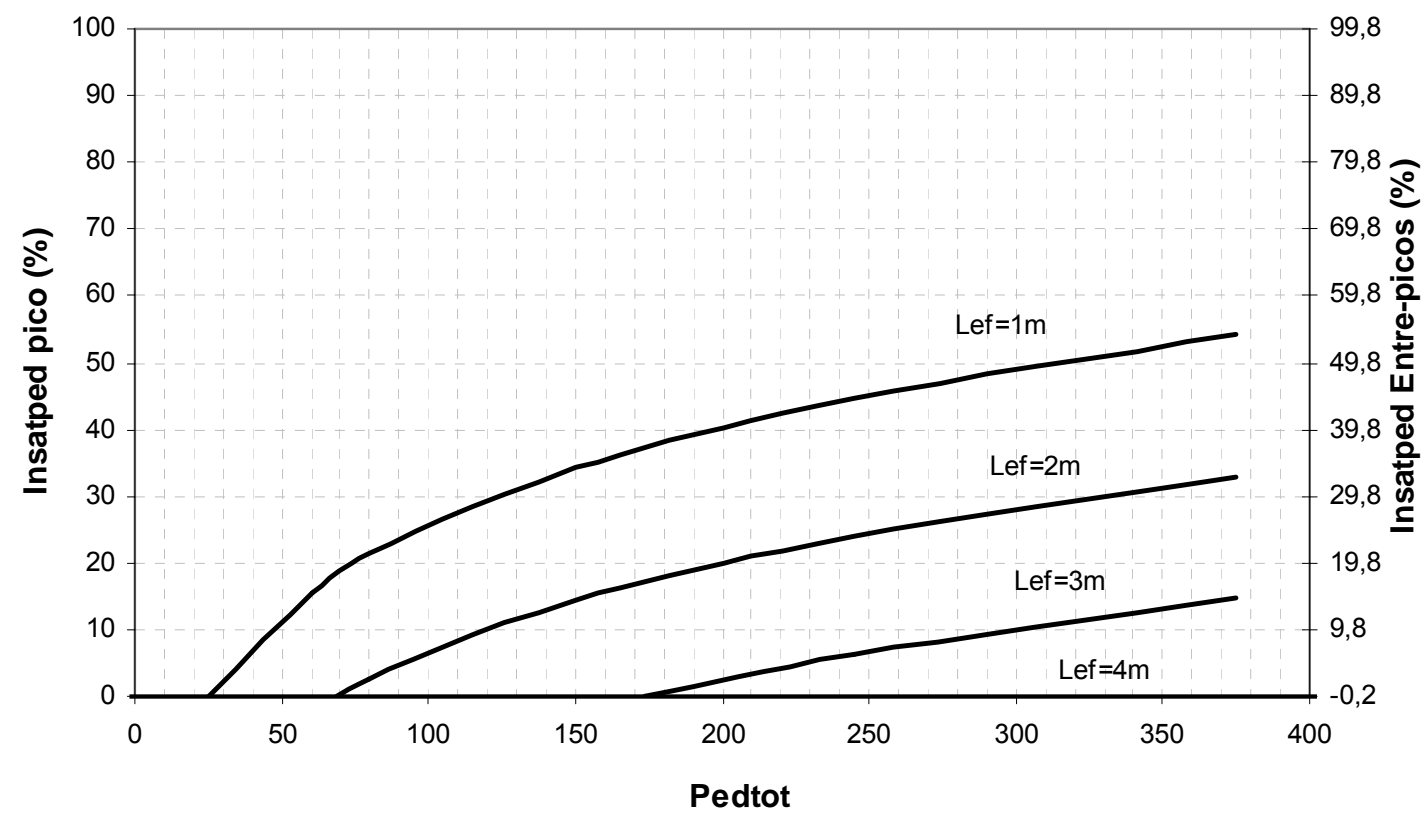

Figura 7.1 - Nomograma para dimensionamento de calçadas desconsiderando o número total de ciclistas.

Observando o nomograma da Figura 7.1, percebe-se que, para calçadas com largura efetiva igual a $4 \mathrm{~m}$, onde não existe o fluxo de ciclistas na via, os pedestres estarão sempre satisfeitos, independentemente do fluxo dos mesmos. Tal fato explica a curva referente à largura efetiva de $4 \mathrm{~m}$, no gráfico, está coincidente com o eixo de pedestres totais, indicando $0 \%$ de insatisfação.

Seguindo o mesmo raciocínio, percebe-se que pedestres que se deslocam por uma calçada com $3 \mathrm{~m}$ de largura efetiva, só começarão a ficar insatisfeitos quando o seu fluxo ultrapassar o valor de 180 pedestres $/ 5$ minutos. Já para calçadas com largura efetiva igual a $2 \mathrm{~m}$, o valor deste fluxo cai para 70 pedestres $/ 5$ minutos, e para calçadas de $1 \mathrm{~m}$ de largura efetiva, a redução é para 25 pedestres $/ 5$ minutos. 


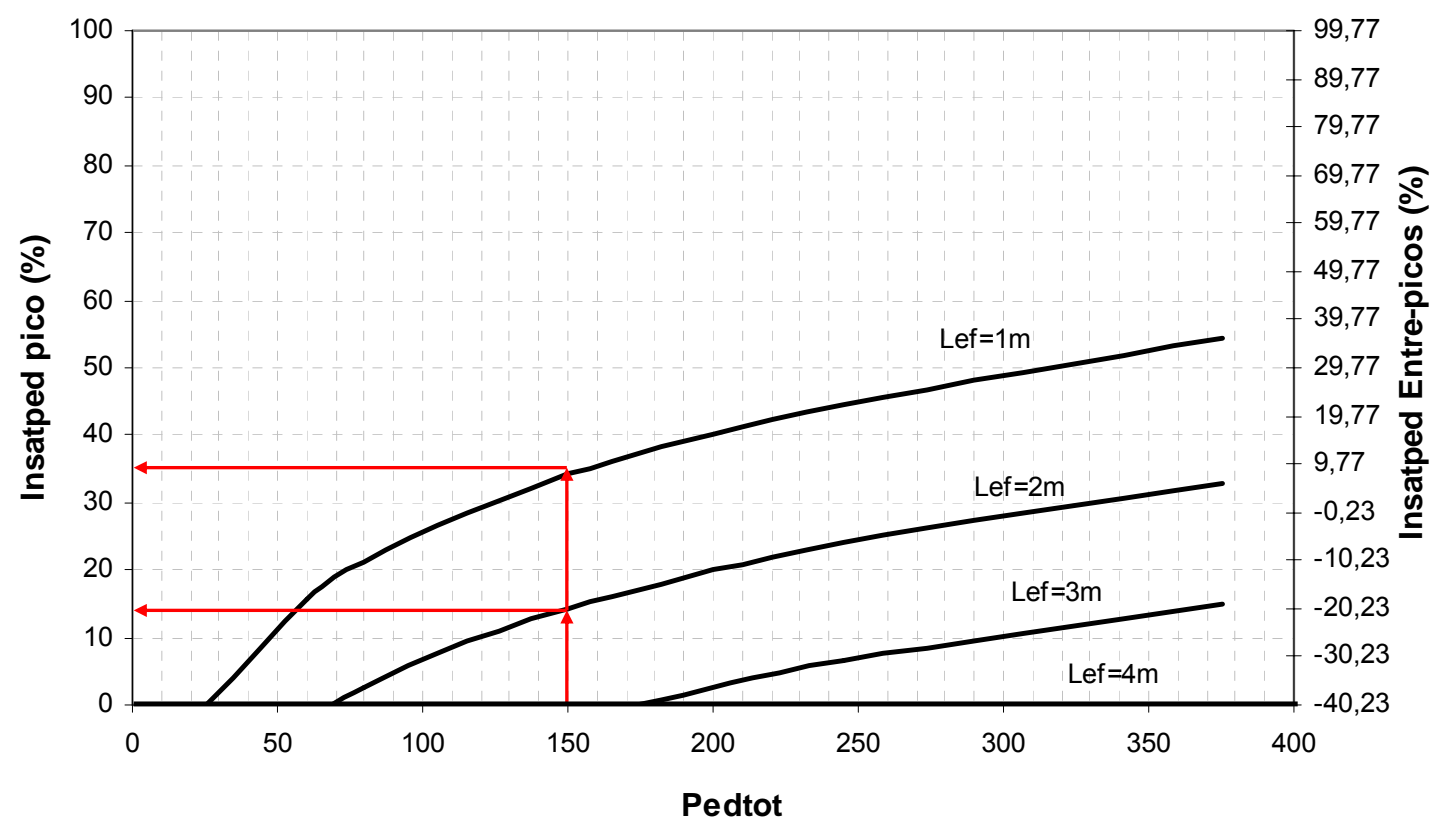

Figura 7.2 - Exemplo de aplicação do Nomograma da Figura 7.1.

Para aplicar o nomograma da Figura 7.1, basta entrar com o número total de pedestres na via e definir a largura efetiva da calçada, em função do nível de serviço desejado. Conforme a Figura 7.2, para o fluxo de 150 pedestres/5 minutos, calçadas com $3 \mathrm{~m}$ e $4 \mathrm{~m}$ de largura efetiva não causam insatisfação alguma aos pedestres. Entretanto, para o mesmo fluxo, calçadas com $1 \mathrm{~m}$ e $2 \mathrm{~m}$ de largura efetiva provocam uma insatisfação de 35\% e 15\%, respectivamente.

Para dimensionar calçadas considerando o número total de ciclistas em uma via, deve-se utilizar o nomograma da Figura 7.3. A diferença deste para o nomograma da Figura 7.1 é a inclusão de curvas referentes ao fluxo de ciclistas na via, e a consideração da parte negativa das curvas de largura efetiva.

O nomograma da Figura 7.3 apresenta uma linha para fluxo de ciclistas igual a 0 (zero), esta será a referência para a obtenção dos outros fluxos de ciclistas. A seguir serão dados alguns exemplos da aplicação do nomograma. 


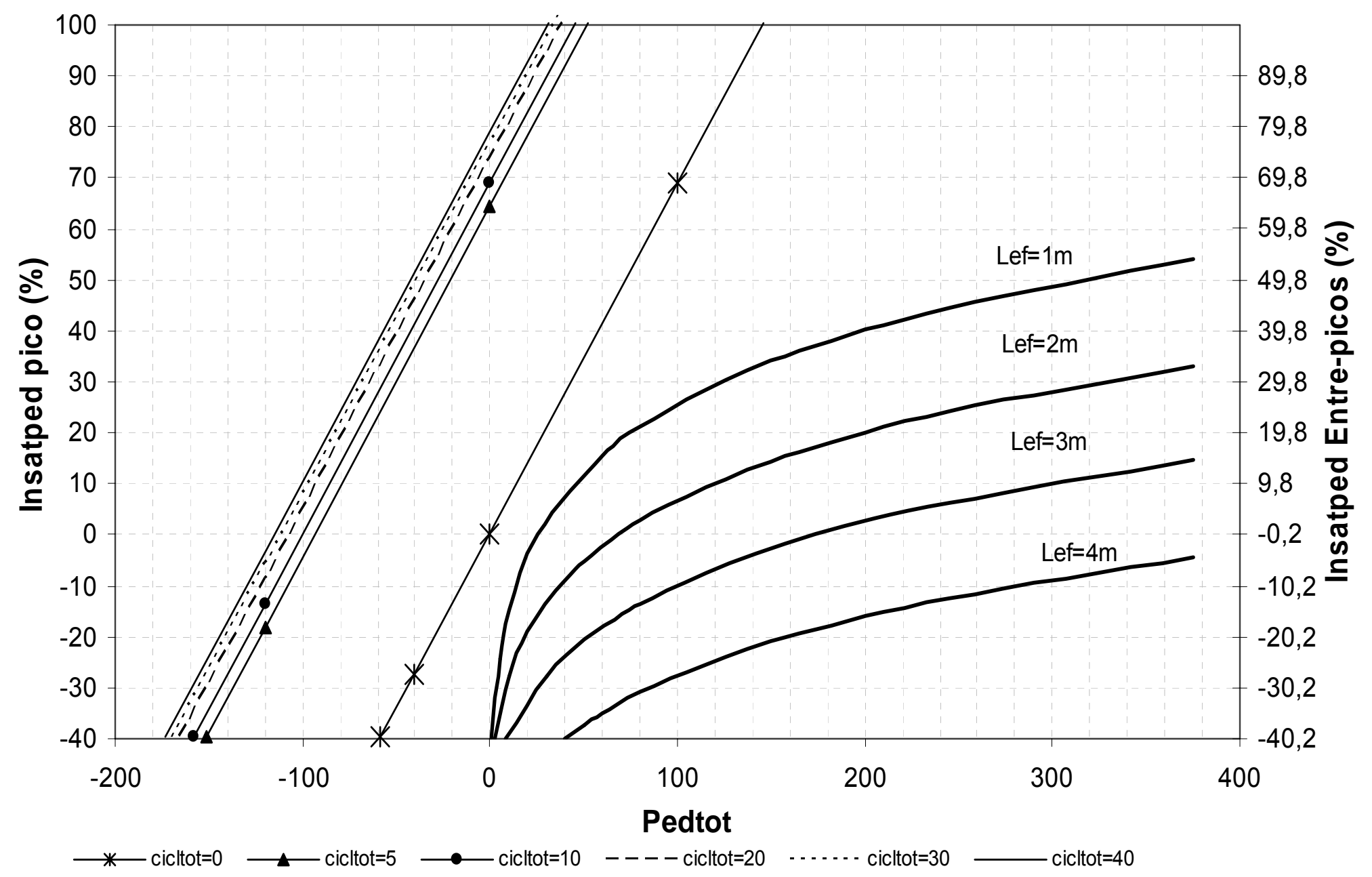

Figura 7.3 - Nomograma para dimensionamento de calçadas considerando o número total de ciclistas. 


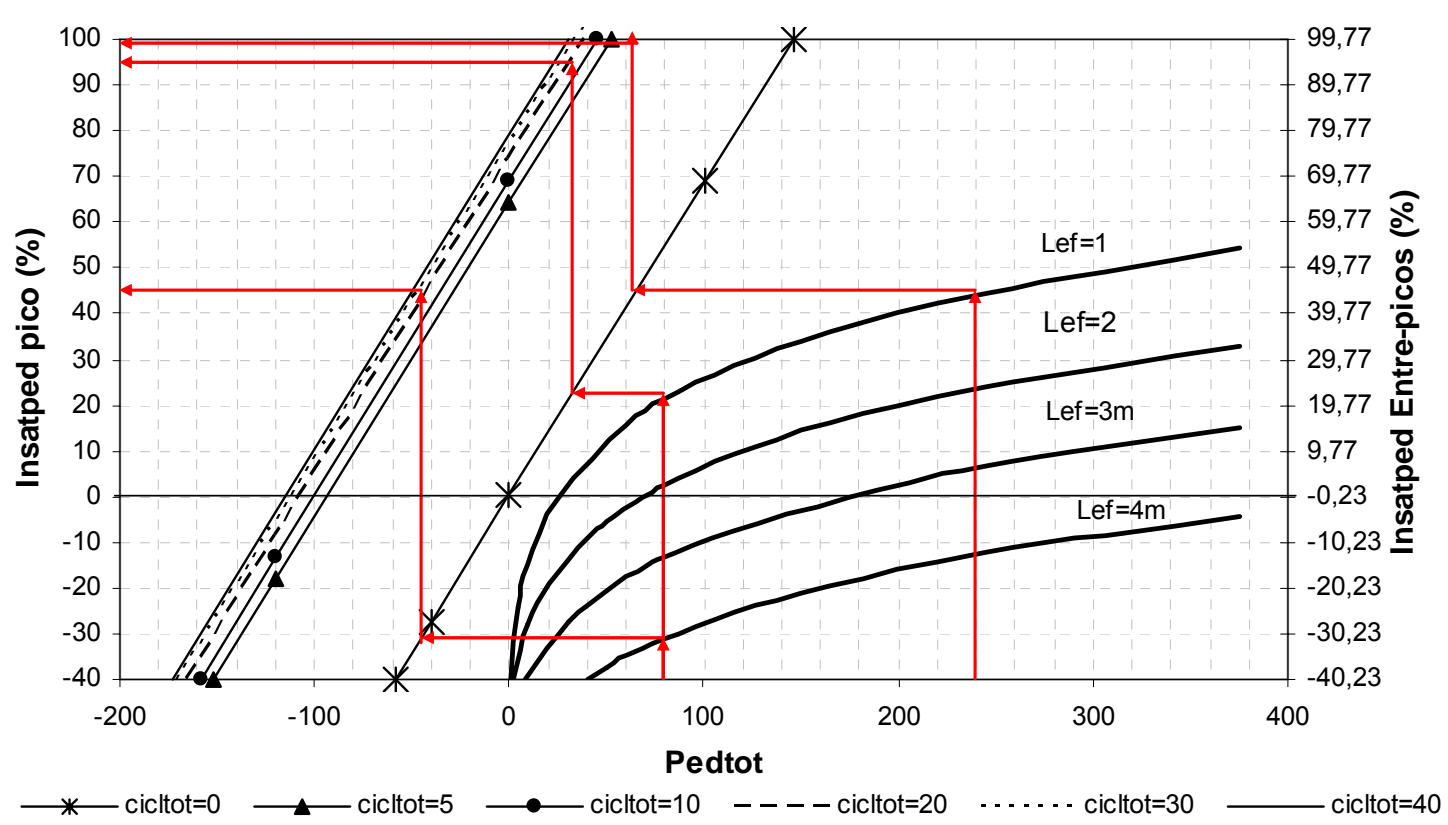

Figura 7.4 - Exemplo de aplicação do Nomograma da Figura 7.3.

Observando a Figura 7.4, percebe-se que para o fluxo de pedestres na via igual a 80 pedestres $/ 5$ minutos, com uma largura efetiva de $1 \mathrm{~m}$, e com um fluxo de ciclistas de 20 ciclistas/5 minutos na via, obtém-se uma insatisfação para pedestres de $95 \%$.

Para um fluxo de 240 pedestres/5 minutos na via, com a mesma largura efetiva de calçada e o mesmo fluxo de ciclistas, percebe-se que a seta vermelha não intercepta a reta de ciclistas igual a 20 , antes, ela intercepta o valor de $100 \%$ de insatisfação. Isto significa que, para a calçada de largura efetiva igual a $1 \mathrm{~m}$, os referidos fluxos de ciclistas e pedestres causam uma insatisfação total nos pedestres sobre a calçada.

Observando-se ainda a Figura 7.4, observa-se que para um fluxo de 80 pedestres $/ 5$ minutos, com uma largura efetiva de $4 \mathrm{~m}$, e com um fluxo de 20 ciclistas $/ 5$ minutos na via, obtém-se um valor de $45 \%$ para a insatisfação dos pedestres.

Pelo modelo proposto, verifica-se que a presença de 1 ciclista/minuto na via aumenta em $54 \%$ a insatisfação dos pedestres. Por este motivo, com o intuito de 
corrigir este incremento, o nomograma da Figura 7.3 considera os valores negativos das curvas referentes à largura efetiva. Assim, conforme observado na Figura 7.4, os valores negativos representam o quanto está sendo reduzida a insatisfação dos pedestres em função de uma largura efetiva maior de calçada.

Convém destacar, que o modelo proposto pode ser utilizado para o cálculo da insatisfação dos pedestres, porém, para o dimensionamento de calçadas recomendase a utilização dos nomogramas apresentados nas Figuras 7.1 e 7.3 , pois ambos são de fácil manuseio e evitam a resolução de equações complexas para alcançar a largura efetiva desejada de calçada. A seguir será dado um exemplo da utilização do nomograma para o dimensionamento de calçadas, considerando um nível de serviço desejado.

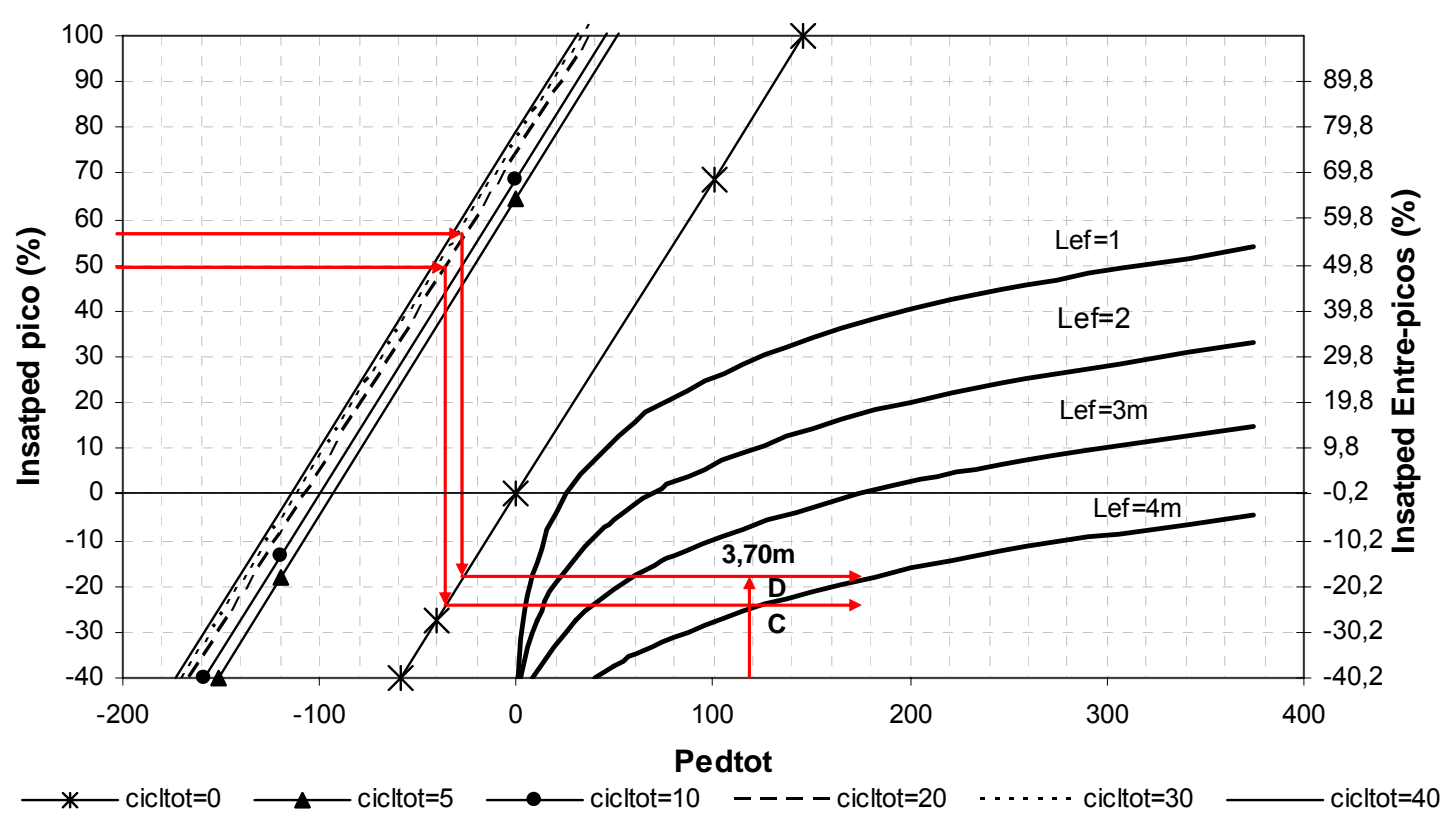

Figura 7.5 - Exemplo de aplicação do Nomograma para dimensionamento de calçadas.

Com base na Figura 7.5, para obter a largura de calçada em função de um nível de serviço desejado, deve-se proceder da seguinte forma:

- selecionar o nível de serviço desejado (nível de serviço C) 
- A partir da insatisfação correspondente ao nível de serviço C (49\%), prolongar um segmento de reta até que esta intercepte a reta referente ao fluxo de ciclistas contados na via (no exemplo, Cicltot=20)

- A partir desta interseção, baixar um segmento de reta até que este intercepte a curva do nível de referência dos ciclistas (Cicltot=0)

- A partir desta interseção, traçar um segmento de reta na direção das curvas das larguras efetivas de calçada. O encontro deste segmento de reta com o segmento de reta que parte do fluxo total de pedestres na via definirá a largura efetiva da calçada, para que o nível de serviço desejado seja alcançado.

Conforme o exemplo dado, para que o nível de serviço desejado (Nível C) seja alcançado, deve-se dimensionar a calçada com uma largura efetiva superior a $4 \mathrm{~m}$, pois com apenas $4 \mathrm{~m}$ de largura efetiva, a calçada já estaria operando em condições limites do nível de serviço $\mathrm{C}$ e com pouco tempo de uso poderia haver uma redução do seu nível de serviço. Na figura 7.5 é identificada a área na qual o nível de serviço C se enquadra, para as condições dos fluxos de ciclistas e pedestres considerados no exemplo dado.

A Figura 7.5 mostra a faixa de largura efetiva que uma calçada deveria ter para que o nível de serviço $D$ fosse atingido, sob as mesmas condições de fluxo de ciclistas e pedestres do exemplo anterior. Percebe-se que com 3,70m de largura a calçada estaria em condições limites do nível de serviço D, portanto, as melhores dimensões para atender ao nível de serviço $D$ devem estar entre 3,70m e $4 \mathrm{~m}$ de largura efetiva, conforme mostrado na Figura 7.5. 


\section{Capítulo 8}

\section{CONCLUSÕES, RECOMENDAÇÕES E SUGESTÕES PARA TRABALHOS FUTUROS}

Nesta pesquisa procurou-se abordar um problema que ocorre com muita freqüência em alguns municípios brasileiros, em virtude destes não apresentarem espaços adequados para a circulação dos transportes não motorizados (ciclistas e pedestres). Com isso, tais usuários acabam transitando pelas vias urbanas sem possuir uma limitação física para realizar os seus deslocamentos, sofrendo a influência do tráfego de veículos motorizados e ao mesmo tempo, provocando conflitos entre si.

O foco principal desta pesquisa foi o pedestre, e por este motivo, procurou-se identificar os parâmetros que mais influenciam o seu comportamento, quando, ao se deslocar por vias urbanas, fica exposto às condições operacionais, geométricas e físicas das mesmas. O tema foi abordado nesta pesquisa de uma forma diferenciada dos demais estudos encontrados na bibliografia.

Procurou-se demonstrar que os ciclistas, em vias onde não existe infra-estrutura para a sua circulação, deixam os bordos destas e tendem a ocupar as calçadas, devido à influência do tráfego dos veículos motorizados. Assim, são gerados conflitos sobre as calçadas, que resultam na perda da qualidade dos deslocamentos dos pedestres. 
Portanto, serão apresentadas aqui, de forma encadeada, as principais conclusões desta pesquisa, considerando o contexto no qual esta se insere, e as particularidades do local estudado, a cidade de Boa Vista. Dentre as principais conclusões desta pesquisa, destacam-se as seguintes:

a) O tráfego de veículos motorizados, nas vias que não possuem qualquer infra-estrutura para a circulação de ciclistas, exerce uma grande influência sobre estes usuários, pois faz com que eles deixem os bordos das vias, e passem a ocupar as calçadas, provocando, assim, conflitos com os pedestres, e conseqüentemente, impõem uma impedância aos deslocamentos destes últimos.

b) Constatou-se que no período do maior fluxo de veículos motorizados - no período de pico - existe uma maior tendência de ocupação das calçadas por parte dos ciclistas. Situação inversa ocorre no período entre-picos. Entretanto, apesar da influência sofrida pelo tráfego motorizado, e pelo período do dia em questão, a presença de ciclistas em uma determinada calçada está diretamente relacionada à quantidade de ciclistas que transitam pela via, pois pôde-se perceber nesta pesquisa que, independentemente do período de observação, pico ou entre-picos, quanto maior for o número de ciclistas na via, maior será a tendência de alguns utilizarem-se da infra-estrutura destinada aos pedestres.

c) A ocupação da calçada pelos ciclistas, no horário de pico, foi em média $21 \%$ maior do que a ocupação pelos pedestres, já no período entre-picos este valor foi de apenas $7 \%$. A partir do número total de ciclistas em uma via, pode-se afirmar que, no período de pico, a quantidade de ciclistas que se utilizará da calçada, poderá ser de até 3 vezes o número de ciclistas que ocupariam a calçada no período entre-picos.

d) O deslocamento dos pedestres é afetado em função da maior ou menor ocupação das calçadas pelos ciclistas. Tal fato fica evidenciado pela diferença do nível de satisfação dos 
pedestres que, obviamente, está relacionada ao período do dia. Conforme mostrado nas Figuras 5.17 a 5.20, há uma tendência maior de satisfação dos pedestres, quando estes realizam seus deslocamentos no período entre-picos, pois neste existe uma menor ocupação das calçadas pelos ciclistas, conforme descrito anteriormente.

e) A técnica da árvore de decisão mostrou-se eficiente, para analisar o comportamento dos pedestres. Após a aplicação desta ferramenta, contida no programa S-Plus 6.1, considerando o conjunto de dados utilizado nesta pesquisa, pode-se concluir que as variáveis que mais influenciam a satisfação dos pedestres, quando estes se deslocam nas calçadas e ficam sujeitos a todas as condições operacionais, físicas e geométricas das vias, são as seguintes: variável categórica pico ou entre-picos; largura efetiva da calçada em metros (Lef); número total de ciclistas na calçada da via dividido pelo número total de pedestres na via (Ciclcal/pedt); número total de ciclistas na calçada por metro de calçada (Ciclical/m); número total de ciclistas na via (Ciclitot); número total de pedestres na calçada por metro de calçada (Pedcal/m); e número de pedestres na calçada da via (Pedcal).

f) Após a análise dos resultados, obtidos pela técnica da árvore de decisão, pode-se afirmar que a largura efetiva de uma calçada, em vias onde não existe um espaço adequado aos deslocamentos dos ciclistas, pode causar uma influência negativa aos pedestres, pois quanto maior for a dimensão de uma calçada maior atratividade esta exercerá sobre os ciclistas. Tal fato provoca a redução da satisfação dos pedestres nos seus deslocamentos.

g) Observando-se os aspectos geométricos, físicos e operacionais de uma via urbana que não possui infra-estrutura para o trânsito de ciclistas, pode-se afirmar, com base no modelo para dimensionamento de calçadas, proposto nesta pesquisa, que a insatisfação dos pedestres é função dos seguintes parâmetros: variável categórica Pico ou Entre-picos; número de pedestres sobre a calçada observada (Pedcal); largura efetiva da calçada observada em metros (Lef); e número total de ciclistas na via em questão (Cicltot). 
h) As variáveis definidas pelo modelo proposto nesta pesquisa, utilizando-se a técnica de regressão robusta $\mathrm{mm}$, a fim de representar a insatisfação dos pedestres, foram semelhantes às encontradas pela técnica da árvore de decisão e classificação, inclusive, guardando entre si, a mesma importância relativa. Tal constatação foi evidenciada após a verificação dos valores da estatística $t$, dos coeficientes do modelo proposto, e da observação dos resultados da árvore de decisão.

i) Pode-se afirmar que, em ordem decrescente de importância, as variáveis que mais influenciam na satisfação dos pedestres, em vias que não possuem infra-estruturas destinadas aos ciclistas, são as seguintes: período pico/entre-picos; largura efetiva da calçada; número de pedestres sobre a calçada observada; e número total de ciclistas na via em questão.

j) O modelo proposto nesta pesquisa apresenta novos parâmetros, em termos do fluxo de pedestres e da insatisfação destes, a fim de diferenciar cada um dos níveis de serviço para calçadas. Os novos limites, acima citados, mostraram-se coerentes com os resultados de outros estudos constantes na bibliografia, os quais consideram o critério da capacidade para definir seus níveis de serviço.

k) O modelo proposto nesta pesquisa pode ser aplicado com confiabilidade, para a avaliação do nível de serviço de calçadas, em outros locais, diferentes daquele onde foi concebido. Para isso, basta que seja desconsiderada, no modelo, a parcela referente ao número total de ciclistas na via. 
I) Dada à consistência do modelo proposto, é possível afirmar que o mesmo pode ser utilizado para avaliar o nível de serviço das calçadas no local onde foi desenvolvido, no caso a cidade de Boa Vista, considerando a parcela referente ao número total de ciclistas na via.

m) O modelo ora proposto pode ser utilizado também no planejamento urbano, para definir largura efetiva de caçadas em vias onde não existem tais infra-estruturas, na cidade de Boa Vista. Para isso, basta fixar o nível de serviço desejado para a calçada, e determinar o número total de pedestres e ciclistas que transitam pela via.

n) O modelo proposto nesta pesquisa considera no dimensionamento de calçadas o nível de satisfação do pedestre, mesmo quanto este usuário tem que dividir a calçada com o fluxo de ciclistas. Tal condição de conflito é prevista e estabelecida pelo CTB (1997), em seu art. 59. Portanto, o planejamento de calçadas considerando o fluxo de ciclistas sobre tais infraestruturas deverá proporcionar condições mais adequadas aos deslocamentos dos pedestres.

o) Como forma de atenuar os conflitos existentes entre pedestres e ciclistas sobre as calçadas das vias, sugere-se que após a definição da dimensão de uma calçada, a partir do modelo proposto nesta pesquisa, seja definida "in loco" uma linha indicativa do espaço destinado à circulação dos ciclistas na calçada, de forma a orientar o fluxo desses usuários e, garantir que o deslocamento dos pedestres seja realizado sob o nível de satisfação préestabelecido pelo modelo.

p) Considerando todas as conclusões apontadas anteriormente, pode-se afirmar que o método utilizado nesta pesquisa, a fim de atingir o objetivo proposto, foi satisfatório. Este mostrou que, a partir de simples contagens de campo, e com a utilização das técnicas de 
árvore de decisão e de regressão robusta mm - ambas contidas no programa S-Plus 6.1 - foi possível identificar os principais parâmetros que influem na satisfação dos pedestres, e conseqüentemente, obter um modelo consistente para o dimensionamento de calçadas e para avaliação do seu nível de serviço.

Após a conclusão desta pesquisa, pretende-se que ela possa servir como subsidio para estudos futuros e como auxílio para os gestores municipais, na tarefa de planejar os espaços urbanos das suas cidades.

Portanto, serão feitas aqui algumas recomendações, em termos de procedimentos a serem adotados, no sentido de melhorar a circulação dos pedestres nas vias urbanas. Dentre as principais recomendações a partir desta pesquisa, destacam-se as seguintes:

\section{1 - Quanto à fiscalização pública}

a) Conforme constatado nesta pesquisa, quanto maior o número de ciclistas em uma via, maior será a tendência destes ocuparem as suas calçadas, prejudicando assim, o deslocamento dos pedestres. Portanto, os órgãos municipais, responsáveis pelo setor de trânsito, podem exercer uma fiscalização rigorosa, principalmente, nas vias que não possuem infra-estrutura destinada aos ciclistas e que apresentam uma demanda razoável de tais usuários, com o fim de abrandar os conflitos com pedestres.

b) Por outro lado, a administração pública deve manter em boas condições as laterais das faixas carroçáveis, locais por onde o ciclista deve trafegar quando não houver ciclovia. Isso significa deixar livre de detritos, poças de água, buracos etc. Parece que a administração, 
principalmente em vias não pavimentadas, tende a conservar mais o centro da faixa que as laterais. Nessas laterais estão obstáculos impostos aos ciclistas: as obras de drenagem (quando existem....), o acúmulo de água, o acúmulo de detritos e as erosões.

\section{2 - Quanto à utilização da árvore de decisão e da regressão robusta mm}

a) Nesta pesquisa as técnicas da árvore de decisão e da regressão robusta mm mostraramse satisfatórias, porém, recomenda-se um cuidado especial na análise dos seus resultados, ou seja, estes devem ser interpretados sempre com a atenção voltada para os fatos ocorridos no campo, a fim de evitar equívocos.

Tal recomendação poder ser exemplificada pelo que ocorreu na presente pesquisa. Esperava-se que o número de ciclistas na calçada (Ciclcal) fosse um dos possíveis parâmetros para reduzir a satisfação dos pedestres, mas o mesmo não apareceu diretamente nos resultados da árvore nem da regressão robusta mm. Porém, constatou-se nesta pesquisa, que quanto maior for o número total de ciclistas (Cicltot) em uma via, maior será a tendência destes ocuparem as calçadas da via. Portanto, os ciclistas nas calçadas são uma parcela do valor de Cicltot, que vez por outra, vêem-se obrigados a subir na calçada, pressionados pelo tráfego de veículos motorizados.

b) O modelo apresentado nesta pesquisa foi gerado em um programa de regressão linear. Portanto, recomenda-se uma atenção especial na sua calibração, pois tal aferição depende da sensibilidade do usuário que, no momento de avaliar os respectivos coeficientes do modelo, deve considerar não apenas o quanto os coeficientes são significativos, mas se as respectivas variáveis representam o fenômeno estudado. 


\section{3 - Quanto à extrapolação do método}

a) Como o método utilizado nesta pesquisa levou a resultados satisfatórios, recomenda-se aos órgãos municipais que utilizem o mesmo procedimento aqui adotado, a fim de desenvolverem seus próprios modelos. Isso pode contribuir para melhor avaliar o nível de serviço das calçadas dos seus municípios, bem como para projetar de forma mais adequada os espaços destinados à circulação dos pedestres, considerando sempre, o nível de satisfação.

\section{4 - Quanto à aplicação do modelo em Boa Vista}

a) Como forma de subsidiar as equipes de campo recomenda-se a utilização das tabelas (7.18 a 7.33), apresentadas no Capítulo 7, para a avaliação do nível de serviço das calçadas na cidade de Boa Vista. As referidas tabelas trazem em seu conteúdo valores limites para fluxos de pedestres e ciclistas, correspondentes a cada um dos níveis de serviço para calçadas.

b) Para o planejamento urbano da cidade de Boa Vista, recomenda-se como forma de auxiliar as equipes de campo, a utilização do ábaco para a determinação da largura efetiva de calçadas, apresentado no Capítulo 7. Assim, a partir de dados coletados "in loco", podese definir a medida do parâmetro desejado, sem a necessidade de máquinas de calcular programáveis.

c) Como o modelo proposto nesta pesquisa pode ser aplicado tanto para a avaliação do nível de serviço de calçadas, como para o dimensionamento de tal infra-estrutura nas vias onde não existe espaço destinado à circulação dos pedestres, recomendam-se abaixo alguns passos que devem ser seguidos para a utilização adequada do modelo. 
Avaliação do Nível de Serviço da calçada

1- Determinar o horário de pico dos veículos motorizados, na via em questão, considerando o local da calçada a ser observada;

2- Determinar a largura efetiva da calçada que se quer avaliar na via em questão (Lef);

3- Determinar o fluxo total de ciclistas, para um período de tempo igual a 5 minutos, na via em questão (Cicltot);

4- Determinar o fluxo de pedestres, para um período de tempo igual a 5 minutos, que passam pela largura efetiva da calçada avaliada (Pedcal);

5- Substituir na equação que representa o modelo I desta pesquisa, todos os valores dos parâmetros citados acima e, com isso, determinar o valor da insatisfação dos pedestres (Insatped);

6- O nível de serviço da calçada avaliada será obtido pelo enquadramento do valor da insatisfação dos pedestres, em um dos limites contidos para o referido parâmetro, na tabela 6.12 do Capítulo 6.

Dimensionamento da largura efetiva de calçadas

1- Determinar o horário de pico, dos veículos motorizados, na via em questão, considerando o local da calçada a ser observada;

2- Determinar o fluxo total de ciclistas, para um período de tempo igual a 5 minutos, na via em questão (Cicltot); 
3- Determinar o fluxo total de pedestres, para um período de tempo igual a 5 minutos, na via em questão (Pedtot);

4- Substituir na equação que representa o modelo I desta pesquisa, os valores dos parâmetros citados acima e, fixar o nível de serviço desejado para calçada, ou seja, definir no referido modelo, um valor para a insatisfação dos pedestres (insatped);

5- Utilizando a função "Atingir metas", no programa Excel 2000, obter a largura efetiva da calçada.

Obs: Para um serviço de campo pode ser utilizado o nomograma proposto no Capítulo 7 desta pesquisa.

\section{Sugestões para trabalhos futuros}

Conforme descrito neste capítulo, o método utilizado na pesquisa foi considerado satisfatório para alcançar o objetivo proposto, ou seja, elaborar um modelo para dimensionar calçadas para pedestres, considerando o nível de satisfação destes. Entretanto, no sentido de tornar mais amplo o estudo aqui desenvolvido sugere-se que em trabalhos futuros seja aplicado o mesmo método, porém, com o acréscimo de outras variáveis ao conjunto de dados, como por exemplo, o Índice de Qualidade das Calçadas, proposto por Ferreira e Sanches (2001), para que se obtenha um modelo que contemple o critério da satisfação dos pedestres, o critério da capacidade e os critérios de conforto, segurança, seguridade, atratividade e manutenção das calçadas. 


\section{REFERÊNCIAS}

ABNT. NBR-9050/1994: Acessibilidade de Pessoas Portadoras de Deficiências à Edificações, Espaço Mobiliado e Equipamentos Urbanos, $2^{\mathrm{a}}$ ed. Disponível em http://www.mj.gov.br/sedh/ct/corde/dpdh/corde/ABNT/NBR9050-31052004.pdf. Acesso em Out. 2003.

AL-KATHAIRI, A.S. et al. (2002). Evaluating the Pedestrian Environment in Abu Dhabi. In: TRANSPORTATION RESEARCH BOARD ANNUAL MEETING, 81 ${ }^{\mathrm{ST}}$, Washington,D.C. Proceedings...Washington: Transportation Research Board. CDROM.

ASSOCIAÇÃO NACIONAL DE TRANSPORTES PÚBLICOS - ANTP (1997). Transporte Humano - Cidades Com Qualidade De Vida, São Paulo, ANTP.

ASSOCIAÇÃO NACIONAL DE TRANSPORTES PÚBLICOS - ANTP. Relatório sobre o transporte público - $\quad$ Conclusão. Disponível em http://www.antp.org.br/telas/congresso transito transporte5.htm. Acesso em Nov $\underline{2005}$.

BREIMAN, L; FRIEDMAN, J. OLSHEN, R; STONE, C. (1984) Classification and Regression Trees. New York, N.Y., Chapman and Hall.

COMPANHIA DE ENGENHARIA DE TRÁFEGO - CET (1978). Áreas de Pedestres Conceito. Boletim Técnico da CET No 17, São Paulo.

CBTU-METROFOR. CBTU - (1979). METROFOR, CBTU-METROFOR, Estação Projeto Conceitual, Fortaleza.

CHILUKURI, V.; VIRKLER, M.R. (2002). Pedestrian Progression: A Viable Alternative In Central Business. Districts. In: TRANSPORTATION RESEARCH BOARD ANNUAL MEETING, $81^{\mathrm{ST}}$, Washington,D.C. Proceedings...Washington: Transportation Research Board. CD-ROM.

COTTRELI, W.D; PAL, D.(2003). Evaluation of Pedestrian Data Needs and Collection Efforts. In: TRANSPORTATION RESEARCH BOARD ANNUAL MEETING, $82^{\text {nd }}$, Washington,D.C. Proceedings...Washington: Transportation Research Board. CDROM. 
CUNHA et al.(2002). Uso De Análise Exploratória De Dados E De Regressão Robusta Na Avaliação Do Crescimento De Espécies Comerciais De Terra Firme Da Amazônia. Revista Árvore, Viçosa-MG, v.26, n.4, p.391-402.

DAAMEN, W; HOOGENDOORN, S.P. (2003). Experimental Research of Pedestrian Walking Behavior. In: TRANSPORTATION RESEARCH BOARD ANNUAL MEETING, $82^{\text {nd }}$, Washington,D.C. Proceedings...Washington: Transportation Research Board. CD-ROM.

DAVIS, G.A.(1998). Method for Estimating the Effect of Traffic Volume and Speed on Pedestrian Safety for Residential Streets. Transportation Research Record, 1636, p110-115. Washington, D.C.

(2001). A Simple Threshold Model Relating Pedestrian Injury Severity To Impact Speed In Vehicle/Pedestrian Crashes. In: Annual Meeting Of Transportation Research Board, $80^{\text {th }}$, Washington,D.C. Proceedings...Washington: Transportation Research Board. CD-ROM.

DIXON; L.(1996). Bicycle And Pedestrian Level-of-Service Performance Measures And Standards For Congestion Management Systems. In: TRANSPORTATION RESEARCH BOARD ANNUAL MEETING, 75 ${ }^{\text {th }}$, Washington,D.C. Proceedings...Washington: Transportation Research Board. CD-ROM.

Dill, J.; Carr, T.(2003). Bicycle Commuting and Facilities in Major U.S. Cities: If You Build Them, Commuters Will Use Them - Another Look. In: TRANSPORTATION RESEARCH BOARD ANNUAL MEETING, 82 ${ }^{\text {nd }}$, Washington,D.C. Proceedings...Washington: Transportation Research Board. CD-ROM.

DUNCAN, C; KHATTAK, A.J.; HUGHES, R.G.(2002). Effectiveness Of Pedestrian Safety Treatments For "Hit-Along-Roadway" Crashes. In: TRANSPORTATION RESEARCH BOARD ANNUAL MEETING, 81 ${ }^{\text {st }}$, Washington,D.C. Proceedings...Washington: Transportation Research Board. CD-ROM.

EMPRESA BRASILEIRA DE PLANEJAMENTO DE TRANSPORTES - GEIPOT (2001) Planejamento Cicloviário: Diagnóstico Nacional. Brasília, D.F..

EMPRESA BRASILEIRA DE PLANEJAMENTO DE TRANSPORTES - GEIPOT (2001). Manual de Planejamento Cicloviário. $3^{a}$ ed, Brasília, D.F.

EMPRESA BRASILEIRA DOS TRANSPORTES URBANOS - EBTU.(1984) Pedestres. Série de Cadernos Técnicos, Brasília, D.F. 
FEDERAL HIGHWAY ADMINISTRATION - FHWA.(1992). Reasons why Bicycling and Walking are and are not being used more extensively as travel modes. Case Study no 1, US Department of Transportation. PD-92-041.

FERREIRA; M.A.G., SANCHES; S.P.(2001). Índice de qualidade das calçadas - IQC. Revista dos transportes públicos- ANTP, $2^{\circ}$ trimestre, pp 47-60.

FERREIRA, C.A.; SOARES, J.F.; CRUZ, F.R.B.(2001). Reconhecimento de padrões em Estatística: Uma abordagem Comparativa, Proceedings of the $\vee$ Brazilian Conference on Neural Networks - v Congresso Brasileiro de Redes Neurais, Brasil, RJ.

FRUIN, J.J.(1971). Pedestrian: Planning And Design. $2^{\mathrm{a}}$ ed, Mobile, Elevator World Inc., $206 \mathrm{p}$.

FUGGER JR, T.F. ET AL.(2001). Analysis of Elderly Pedestrian Gait and Perception/Reaction at Signal-Controlled Crosswalk Intersections. In: TRANSPORTATION RESEARCH BOARD ANNUAL MEETING, $80^{\text {th }}$, Washington,D.C. Proceedings...Washington: Transportation Research Board. CD-ROM.

GODIM; M.F., AZEVEDO FILHO; M.A.N.; PORTO FILHO; W.(2001). O Transporte Não Motorizado Na Legislação Urbana No Brasil. 2001, 201f. Dissertação (Mestrado em Transportes). Universidade Federal do Rio de Janeiro - COPPE/UFRJ. Rio de Janeiro, Abril.

HOOK, W.(1995). Economic Importance Of Nonmotorized Transportation. In: TRANSPORTATION RESEARCH BOARD ANNUAL MEETING, 74 ${ }^{\text {th }}$, Washington,D.C. Proceedings....Washington: Transportation Research Board. CD-ROM.

HIGHWAY CAPACITY MANUAL.(2000) Transportation Reearch Board. National Research Council, Washington.

HUBER, P. J.(1973). Robust Statistics:asymptotics, conjectures and Monte Carlo Annals of Statistics. $1^{\text {a }}$ ed, Monte Carlo, p.799-821.

(1981). Robust Statistics. John Wiley \& Sons, Inc., New York.

INSTITUTO DE PESQUISA ECONÔMICA APLICADA (2003). Impactos Sociais e Econômicos dos Acidentes de Trânsito Nas Aglomerações Urbanas. Disponível em http://www.ipea.gov.br/TemasEspeciais/acidentesdetransito.pdf. Acesso em Outubro $\underline{2003}$. 
KHISTY, C.J.(1994). Evaluation of Pedestrian Facilities: Beyond the Level - of - Service Concept. Transportation Research Record 1438, TRB, National Research Council,

Washington, D.C., pp. 45- 50.

LANDIS; B. W., VATTIKUTI V. R., OTTENBERG R. M., MCLEOD D. S., GUTTENPLAN; M.(2001). Modeling The Roadside Walking Environment: A Pedestrian Level Of Service. In: TRANSPORTATION RESEARCH BOARD ANNUAL MEETING, $80^{\text {th }}$, Washington,D.C. Proceedings...Washington: Transportation Research Board. CDROM.

LAUTSO; K., MUROLE; P.(1974). A Study of Pedestrian Traffic in Helsinki: Methods and Results. Traffic Engineering and Control, pp. 446- 449.

LITMAN, A.. Economic Value of Walkability.(2003). In: TRANSPORTATION RESEARCH BOARD ANNUAL MEETING Annual, 82 ${ }^{\text {nd }}$, Washington,D.C. Proceedings Washington: Transportation Research Board. CD-ROM.

MCDONALD, C.H.; BURNS, E.K.(2001). Cycling to Work in Phoenix: Route Choice, Travel Behavior, and Commuter Characteristics. In: TRANSPORTATION RESEARCH BOARD ANNUAL MEETING, 80 ${ }^{\text {th }}$, Washington,D.C. Proceedings...Washington: Transportation Research Board. CD-ROM.

MCLEOD; D.S.(2000). Multimodal Arterial Level of Service. Transportation Research Circular: Fourth International Symposium on Highway Capacity, pp. 221- 233.

MESA, D.M.; TSAI, P.; CHAMBERS, R.L.(2000). Using Tree-Based Models for Missing Data Imputation: Na Evaluation Using UK Census Data. Forthcoming in Research Papers of Statistics Netherlands. Currently available in the Autlmp Website.

MORETTI, R.S.(1993). Critérios de Urbanização para Empreendimentos Habitacionais, Tese de doutorado em Engenharia, Escola politécnica da Universidade de São Paulo,São Paulo.

MORI, M.; TSUKAGUCHI, H.A.(1987). A New Method for the Evaluation of Level of Service in Pedestrian Facilities. Transportation Research A, Vol. 21 A, n. 3, p. $223-$ 234. 
MOUDON, A.V. ET AL.(2002). Pedestrian Location Identification Tools: Identifying Suburban Areas with Potentially High Latent Demand for Pedestrian Travel. In: TRANSPORTATION RESEARCH BOARD ANNUAL MEETING, 81 ${ }^{\text {st }}$, Washington,D.C. Proceedings...Washington: Transportation Research Board. CD-ROM.

MURALEETHARAN, T. et al. (2004). Evaluation of Pedestrian Level-of-Service on Sidewalks and Crosswalks Using Conjoint Analysis. In: TRANSPORTATION RESEARCH BOARD ANNUAL MEETING, 83 ${ }^{\text {rd }}$, Washington,D.C. Proceedings....Washington: Transportation Research Board. CD-ROM.

(2004). Method to Determine Overall Level-of-Service of Pedestrians on Sidewalks and Crosswalks based on Total Utility Value. In: TRANSPORTATION RESEARCH BOARD ANNUAL MEETING, 83 ${ }^{\text {rd }}$, Washington,D.C. Proceedings...Washington: Transportation Research Board. CD-ROM.

NADERI, J.R.; RAMAN, B.(2002). Design Considerations in Simulating Interactive Virtual Pedestrian Environments. In: TRANSPORTATION RESEARCH BOARD ANNUAL MEETING, 81 ${ }^{\text {st }}$, Washington,D.C. Proceedings...Washington: Transportation Research Board. CD-ROM.

PITOMBO, C.S.; KAWAMOTO, E. (2004) Estudo do comportamento individual relacionado ao encadeamento de viagens através do uso de minerador de dados. XIII Panamerican Conference/ Conference Papers, 2004. In: XIII Panamerican Conference of Traffic and Transportation Engineering, 2004, Albany.

PRINZ, D. (1980). Urbanismo 1, Projecto Urbano, Lisboa, Editorial Presença.

PUPPI, I. C.(1981). Estruturação Sanitária das Cidades, CETESB, São Paulo.

ROUSSEEUW P. J. \& YOHAI, J. V.(1984). Robust regression by means of Sestimator. In Robust and Nonlinear Time Series (J. Franke, W. H“ardle and D. Martin, eds) Lecture Notes in Statist., 26, 256-272. Springer, New York.

ROUSSEEUW, P.J.(1984). Least Median Squares Regression. Journal of American Statistical Association $\mathrm{N}^{0} 79,871-880$.

ROUSSEEUW, P.J. and Van Driessen, K.(1998). A fast Algorithm for the Minimum Covariance Determinant Estimator cited in SAS OnLineDoc.

SARKAR; S.(1993). Determination of Service Levels for Pedestrians, with European Examples. Transportation Research Record 1405, TRB, National Research Council, Washington, D.C., 1993, pp. 35- 42. 
SISIOPIKU,V.P.; ZHANG, X; VIRKLER, M.R. (2002). Pedestrian Level Of Service And Quality Of Operations Assessment Methods. In: TRANSPORTATION RESEARCH BOARD ANNUAL MEETING, 81 ${ }^{\text {st }}$, Washington,D.C. Proceedings...Washington: Transportation Research Board. CD-ROM.

SOUZA,M.A.B. (1994). Implantação e execução de projetos de arborização urbana In II Congresso Brasileiro de Arborização Urbana, São Luis.

STINSON, M.A. E BHAT, C.R.(2003). An Analysis of Commuter Bicyclist Route Choice Using a Stated Preference Survey. In: TRANSPORTATION RESEARCH BOARD ANNUAL MEETING, 82 ${ }^{\text {nd }}$, Washington,D.C. Proceedings...Washington: Transportation Research Board. CD-ROM.

YOHAI, V. J. (1987). High Breakdown-point And High Efficiency Robust Estimates For Regression. Annals of Statistics, 15(2), 1987. p.642-656. 


\section{APÊNDICE A}


EXEMPLO DA PLANILHA DE CONTAGEM

\begin{tabular}{|c|c|c|c|c|c|c|c|c|c|c|c|c|c|c|}
\hline Hora & Pico & PedCal & PedFora & Ciclcal & Ciclfora & Auto & moto & Ônibus & $\begin{array}{c}\text { Caminhão } \\
\text { Gd }\end{array}$ & $\begin{array}{c}\text { Caminhão } \\
\mathrm{Pq}\end{array}$ & $\begin{array}{c}\begin{array}{c}\text { Insatped } \\
(\%)\end{array} \\
\end{array}$ & Lef $(m)$ & $\begin{array}{c}N^{\circ} \\
\text { faixas }\end{array}$ & Largfaixas $(\mathrm{m})$ \\
\hline $7: 15-7: 20$ & 0 & 6 & 2 & 9 & 4 & 56 & 34 & 2 & 1 & 0 & 0,67 & 2 & 2 & 4.20 \\
\hline
\end{tabular}

\begin{tabular}{|c|c|c|c|c|c|c|c|c|c|c|c|c|c|c|}
\hline Hora & $\begin{array}{c}\text { Entre } \\
\text { Picos }\end{array}$ & PedCal & PedFora & Ciclcal & Ciclfora & Auto & moto & Ônibus & $\begin{array}{c}\text { Caminhão } \\
\text { Gd }\end{array}$ & $\begin{array}{c}\text { Caminhão } \\
\text { Pq }\end{array}$ & $\begin{array}{c}\text { Insatped } \\
(\%)\end{array}$ & $\begin{array}{c}N^{\circ} \\
\text { Lef }(\mathrm{m})\end{array}$ & $\begin{array}{c}\text { faixas } \\
\text { Largfaixas(m) }\end{array}$ \\
\hline $\begin{array}{c}9: 00- \\
9: 05\end{array}$ & 1 & 6 & 1 & 7 & 9 & 65 & 30 & 1 & 2 & 0 & 0,33 & 0,9 & 2 & 4,05 \\
\hline
\end{tabular}




\section{EXEMPLO DA PLANILHA DE CONTAGEM ADAPTADA}

\begin{tabular}{|c|c|c|c|c|c|c|c|c|c|c|c|c|c|}
\hline Hora & Pico & PedCal & PedFora & Ciclcal & Ciclfora & Auto & moto & Ônibus & $\begin{array}{c}\text { Caminhão } \\
\text { Gd }\end{array}$ & $\begin{array}{c}\text { Caminhão } \\
\text { Pq }\end{array}$ & $\begin{array}{c}\text { Insatped } \\
(\%)\end{array}$ & $\begin{array}{c}N^{0} \\
\text { Lef }(m)\end{array}$ & $\begin{array}{c}\text { faixas } \\
\text { Largfaixas }(\mathrm{m})\end{array}$ \\
\hline $7: 15-7: 20$ & 0 & 6 & 2 & 9 & 4 & 56 & 34 & 2 & 1 & 0 & 0,67 & 2 & 2 \\
4
\end{tabular}

\begin{tabular}{|c|c|c|c|c|c|c|c|c|c|c|c|}
\hline Hora & Cicltot & Cam & Cambus & Pedtot & Pedcal $/ \mathrm{m}$ & Pedtot $/ \mathrm{m}$ & Ciclcal $/ \mathrm{m}$ & Ciclcal $/$ pedt & Pedfora/m & Cicltot/pedt & Cicltot/m \\
\hline $7: 15-7: 20$ & 13 & 1 & 3 & 8 & 3 & 4 & 4,5 & 1,125 & 1 & 1,625 & 6,5 \\
\hline
\end{tabular}

\begin{tabular}{|c|c|c|c|c|c|c|c|c|c|c|c|c|c|}
\hline Hora & $\begin{array}{c}\text { Entre } \\
\text { Picos }\end{array}$ & PedCal & PedFora & Ciclcal & Ciclfora & Auto & moto & Ônibus & $\begin{array}{c}\text { Caminhão } \\
\text { Gd }\end{array}$ & $\begin{array}{c}\text { Caminhão } \\
\text { Pq }\end{array}$ & $\begin{array}{c}\text { Insatped } \\
(\%)\end{array}$ & $\begin{array}{c}N^{0} \\
\text { Lef }(\mathrm{m})\end{array}$ & $\begin{array}{c}\text { faixas } \\
\text { Largfaixas }(\mathrm{m})\end{array}$ \\
\hline $\begin{array}{c}9: 00- \\
9: 05\end{array}$ & 1 & 6 & 1 & 7 & 9 & 65 & 30 & 1 & 2 & 0 & 0,33 & 0,9 & 2 \\
\hline
\end{tabular}

\begin{tabular}{|c|c|c|c|c|c|c|c|c|c|c|c|}
\hline Hora & Cicltot & Cam & Cambus & Pedtot & Pedcal $/ \mathrm{m}$ & Pedtot/m & Ciclcal $/ \mathrm{m}$ & Ciclcal/pedt & Pedfora/m & Cicltot/pedt & Cicltot/m \\
\hline $\begin{array}{c}\text { 9:00- } \\
\text { 9:05 }\end{array}$ & 16 & 2 & 3 & 7 & 6,7 & 7,8 & 7,8 & 1 & & & \\
\end{tabular}

